\title{
Investigação de esgotamento físico e emocional (burnout) entre professores \\ usuários de um hospital público do \\ município de São Paulo
}

Elaine Cristina Simões

Dissertação apresentada ao Programa de Pós-Graduação em Saúde Pública da Faculdade de Saúde Pública da Universidade de São Paulo para obtenção do título de Mestre em Ciências.

Área de Concentração: Epidemiologia

Orientadora: Prof $\stackrel{a}{ }$. Dra ${ }^{\mathrm{a}}$. Maria Regina Alves Cardoso

São Paulo

2014 
É expressamente proibida a comercialização deste documento, tanto na sua forma impressa como eletrônica. Sua reprodução total ou parcial é permitida exclusivamente para fins acadêmicos e científicos, desde que na reprodução figure a identificação do autor, título, instituição e ano da dissertação. 
Dedico aos meus pais, João e Elvina, pelo apoio e confiança de sempre. 


\section{AgRAdECIMENTOS}

Foram inúmeras pessoas que contribuíram para a execução desse trabalho. Não seria possível nomear a todos nesse espaço, porém, agradeço primeiramente a todos os professores, participantes da pesquisa ou não que, ao longo dos 18 anos de atendimento na Seção de Psiquiatria e Psicologia do Adulto do HSPM, ajudaram-me a construir o entendimento que procuro transpor neste momento.

Agradecimento especial à parceria da orientadora Prof ${ }^{\mathrm{a}}$. Dr ${ }^{\mathrm{a}}$. Maria Regina Alves Cardoso.

Agradeço aos amigos que de maneira muito próxima colaboraram durante o processo de elaboração desse trabalho com seu apoio e sugestões: Moacir Simardi Neto; Dra. Susana P. P. Giannini; Adriane Torres Colozio; Dr. Maurilio Azzi; Dr. Franklin S. Frank e Dr. Alexandre J. Vasconcelos.

Agradeço também aos profissionais do HSPM, que contribuíram por meio do encaminhamento de participantes, e aos professores da Faculdade de Saúde Pública. 


\section{RESUMO}

Este estudo teve por objetivo avaliar aspectos da saúde e do trabalho de professores da rede pública da cidade de São Paulo, usuários do Hospital do Servidor Público Municipal. A síndrome de burnout, ou síndrome de esgotamento profissional, foi considerada como risco ocupacional nessa categoria. Não encontramos outros estudos utilizando instrumento para avaliação de burnout em professores do município. Participaram da pesquisa 76 docentes com indicação de tratamento psicológico. A investigação consistiu na aplicação de inventários para avaliação de burnout: Maslach Burnout Inventory (MBI) e Cuestionario para la Evaluación del Síndrome de Quemarse por el Trabajo (CESQT); aplicação de questionário sociodemográfico e ocupacional e entrevista semiestruturada. Foram realizadas análises estatísticas sendo encontrada associação entre o número de alunos atendidos e a situação funcional e também associação entre o sentimento de realização profissional e: acústica, ruído, poeira, limpeza da sala de aula, número de alunos atendidos, incômodo com os alunos, incômodo com os pais e duração da licença médica. 33,96\% dos medicamentos em uso regular estavam relacionados à síndrome metabólica e 30,82\% a transtornos psiquiátricos. A avaliação dos participantes de que seus problemas de saúde tinham relação com o trabalho mostrou associação com: ter sofrido agressão dentro da escola; conhecer outras vítimas de agressão; duração da licença médica; e número de alunos atendidos. 51,32\% referiram ter sofrido agressão dentro da escola no último ano. 78,95\% relataram agressão sofrida por outras pessoas (sendo 81,67\% outros professores) no mesmo período. A apuração do MBI apontou nível alto de burnout em pelo menos uma escala em 76,31\% da amostra. A apuração do CESQT apontou burnout em 85,52\% dos participantes. Os resultados dos testes psicológicos apresentaram concordância $(p<0,001)$. O MBI mostrou associação com 19 variáveis sociodemográficas e o CESQT com 11 delas, indicando que aspectos do contexto de trabalho estão relacionados ao burnout apurado por meio dos inventários. Consideramos que a democratização do ensino e a proposta da aprendizagem em ciclos transformaram o modelo educacional, trazendo benefícios, porém seriam necessários mais investimentos, bem como a adequação de 
aspectos como: número de alunos atendidos diariamente, educação continuada dos profissionais e estímulos ao apoio mútuo entre professores, coordenadores pedagógicos e diretores de escola.

Descritores e Palavras-chave: professores, burnout, esgotamento profissional, MBI, CESQT. 


\section{ABSTRACT}

This study aimed at evaluating aspects of health and work of public school teachers from the city of São Paulo, users of the Hospital do Servidor Público Municipal (Municipal Public Servant Hospital). Burnout syndrome was considered as an occupational risk in this category. We did not find other studies using instrument for assessing burnout in teachers of the municipality. 76 teachers with indication for psychological treatment participated in the survey. The investigation consisted of the application of inventories for assessment of burnout: Maslach Burnout Inventory (MBI) and Cuestionario para la Evaluación del Síndrome de Quemarse por el Trabajo (CESQT); application of socio-demographic and occupational questionnaire and semi-structured interviews. Statistical analyzes were performed and association was found between the number of students served and the functional condition and also association between feeling of job satisfaction and: acoustic, noise, dust, classroom cleanliness, number of students served, annoyance by students, annoyance by parents, and duration of sick leave. $33.96 \%$ of the drugs in regular use were related to metabolic syndrome and $30.82 \%$ to psychiatric disorders. The participants' assessment that their health problems were related to work was associated with: having suffered physical aggression within the school; knowledge of other victims of aggression; duration of sick leave; and number of students served. 51.32\% reported having experienced physical aggression within the school in the last year. $78.95 \%$ reported physical aggression suffered by other persons (being $81.67 \%$ other teachers) in the same period. The calculation of the MBI showed high level of burnout in at least one scale in $76.31 \%$ of the sample. The calculation of the CESQT pointed burnout in $85.52 \%$ of the participants. The results of the psychological tests agreed to each other $(\mathrm{p}<0.001)$. The MBI was associated with 19 socio-demographic variables and the CESQT with 11 of them, suggesting that aspects of the workplace are related to burnout according to the inventories. We considered that the democratization of education and the proposal of learning cycles have transformed the educational model, bringing benefits, but more investments are needed, as well as the adequacy of aspects as: number of students served daily, continuing professional education and 
incentives to mutual support between teachers, pedagogical coordinators and school principals.

Descriptors and keywords: teachers, burnout, MBI, CESQT. 


\section{LISTA DE TABELAS}

Tabela 1. Versões brasileiras do MBI e seus valores de fidedignidade a 22 de Cronbach

Tabela 2. Consistência interna do MBI - Teste a de Cronbach 22 comparação transcultural

Figura 1 Distribuição percentual dos participantes segundo faixas 35

Tabela 3. Distribuição dos professores conforme a região em que 36 trabalhavam

Tabela 4. Distribuição dos professores de acordo com o número de 37 pessoas com quem residiam

Tabela 5. Origem de outras rendas na residência do professor 37

Tabela 6. Atividades de lazer praticadas pelos professores 38

Tabela 7. Distribuição dos participantes conforme sua situação funcional 39

Tabela 8. Relação entre o tempo de atuação na educação e o estado 39 civil dos participantes

Tabela 9. Distribuição por faixas temporais do ano de início como 40 professor na rede pública municipal

Tabela 10. Distribuição dos participantes conforme a jornada semanal de trabalho

Tabela 11. Distribuição da amostra segundo o nível educacional atendido e o número de cargos assumidos pelos professores

Tabela 12. Relação entre número de cargos e situação funcional dos participantes

Tabela 13. Distribuição dos participantes que tinham interesse em outra 44 ocupação segundo áreas

Tabela 14. Avaliação dos participantes sobre o ambiente físico da escola 45 e salas de aula

Tabela 15. Avaliação dos professores sobre aspectos do ambiente 46 escolar

Tabela 16. Categorias de problemas identificados nas escolas pelos 46 participantes

Tabela 17. Relação entre o número de alunos atendidos e a situação 48 funcional dos pesquisados

Tabela 18. Identificação da causa do incômodo no contato com os alunos 48

Tabela 19. Frequência de mau comportamento dos alunos 49

Tabela 20. Avaliação de aspectos burocráticos e do contato com os pais 49 dos alunos

Tabela 21. Causas de incômodo no contato com os pais dos alunos $\quad 50$

Tabela 22. Aspectos relacionados à coordenação, aos colegas e à 50 instituição escolar

Tabela 23. Avaliação da própria saúde do ponto de vista dos participantes 51

Tabela 24. Distribuição dos remédios em uso regular pelos participantes, 52 conforme categorias medicamentosas

Tabela 25. Problemas de saúde referidos pelos participantes, em 53 categorias

Tabela 26. Quantidade de licenças médicas utilizadas pelos participantes $\quad 54$ 
Tabela 27. Distribuição em faixas temporais da carreira e dos períodos de

licença mais longos

Tabela 28. Distribuição dos participantes conforme sua situação funcional no momento da pesquisa e o motivo pelo qual solicitou sua última licença médica

Tabela 29. Relação entre o número de alunos atendidos diariamente e o motivo da última licença médica

Tabela 30. Avaliação da relação entre o trabalho e seus problemas de saúde e a quantidade de alunos atendidos diariamente pelo participante

Tabela 31. Modos pelos quais os participantes sentem 0 trabalho afetando sua saúde

Tabela 32. Tipo de agressão ou violência sofrida fora da escola, pelo participante, no período de até doze meses antes da pesquisa

Tabela 33. Danos atribuídos à agressão sofrida fora da escola, pelo participante, no período de até doze meses antes da pesquisa

Tabela 34. Agressões sofridas pelos participantes dentro da escola no período de até doze meses antes da pesquisa

Tabela 35. Danos relacionados pelos participantes à agressão sofrida dentro da escola

Tabela 36. Relação entre ter sido agredido na escola e a consideração de que o trabalho está relacionado aos seus problemas de saúde

Tabela 37. Outras pessoas que sofreram agressão no período de até doze meses antes da pesquisa, conforme relatado pelos participantes

Tabela 38. Tipos de agressão a outras pessoas ocorridas no período de até doze meses antes da pesquisa

Tabela 39. Danos físicos e emocionais referidos pelos participantes como consequência de agressões sofridas por outras pessoas

Resultados obtidos pelos participantes em cada escala do MBI

Tabela 40. quantidade de escalas em que atingiram burnout no $\mathrm{MBI}$

Figura 2. Gráfico da distribuição dos participantes de acordo com a 66 intensidade de burnout aferida por meio do MBI

Tabela 42. Resultados obtidos pelos participantes nas escalas do CESQT

Tabela 43. Distribuição dos participantes conforme intensidade de burnout no CESQT

Figura 3. Distribuição dos participantes conforme a quantidade de 68 escalas de burnout atingidas no CESQT

Tabela 44. Relação entre os resultados dos participantes na escala Exaustão Emocional do MBI e na escala Desgaste Psíquico do CESQT 


\section{ÍNDICE}

\section{INTRODUÇÃO}

1.1. Burnout ou síndrome do esgotamento profissional - grupos mais 15 afetados

1.2. Prevalência de burnout entre professores

1.3. Investigação de burnout e confiabilidade do MBI 18

1.4. MBI no Brasil 20

1.5. Instrumentos para avaliação de burnout em professores 22

1.6. O trabalho do professor e o contexto pedagógico no Brasil 23

1.7. Burnout entre professores da rede pública municipal de São Paulo 27

\section{OBJETIVOS}

2.1. Objetivo Geral

2.2. Objetivos específicos 29

3. MÉTODOS 30

3.1. População de estudo 30

3.2. Amostra 30

3.3. Definição de caso 30

3.4. Instrumentos 31

3.5. Características da escola e do indivíduo 31

3.6. Análise dos dados 33

3.7. Questões Éticas 33

4. RESULTADOS

4.1. Caracterização da amostra 35

4.2. Aspectos ocupacionais 38

4.3. Aspectos motivacionais 43

4.4. Aspectos relacionados ao ambiente físico da escola e das salas de $\quad 44$ aula

4.5. Aspectos relacionados ao contato com os alunos, pais e colegas 47

4.6. Aspectos relacionados à saúde e licenças médicas 51

4.7. Aspectos relacionados à violência, ou agressão, dentro e fora da 58 escola

4.7.1. Situações de agressão fora da escola - dirigidas ao participante 58

4.7.2. Agressão ou violência dentro da escola - dirigida ao participante $\quad 59$

4.7.3. Agressão ou violência - dirigida a outras pessoas 61

4.8. Resultados das avaliações de desgaste profissional 63

4.8.1. Apuração do MBI 64

4.8.2. Apuração do CESQT 66

4.8.3. Comparação entre MBI e CESQT 68

5. DISCUSSÃO 71

5.1. Características sócio demográficas $\quad 74$

5.2. Aspectos motivacionais e do contexto escolar 78

5.3. Aspectos de saúde $\quad 80$

5.4. Violência e agressividade no cotidiano escolar 82

5.5. Análise das avaliações de desgaste profissional 83 
6. CONCLUSÕES

7. REFERÊNCIAS

\section{ANEXOS}

Anexo 1 - Termo de Consentimento Livre e Esclarecido Anexo 2 - Inventário CESQT

Anexo 3 - Roteiro de Entrevista

Anexo 4 - Aspectos sócio-demográficos e ocupacionais

Anexo 5 - Relação completa de medicamentos em uso regular Anexo 6 - Apuração de resultados individuais no MBI

Anexo 7 - Apuração de resultados individuais no CESQT

\section{CURRÍCULO LATTES}




\section{INTRODUÇÃO}

A saúde pública envolve múltiplos aspectos, entre eles a saúde ocupacional, a qual se dirige ao estudo dos riscos inerentes aos processos laborais e presentes no ambiente de trabalho. Este estudo tem por objeto avaliar aspectos da saúde e do trabalho de professores da rede pública do município de São Paulo, usuários do Hospital do Servidor Público Municipal (HSPM), considerando como risco ocupacional nessa categoria a síndrome de burnout, ou síndrome de esgotamento profissional.

A síndrome de "burnout" foi conceitualizada nos E.U.A., na década de 70. É entendida como quadro de esgotamento físico e emocional que afeta principalmente trabalhadores dedicados ao atendimento de pessoas, sendo considerada consequência de estressores emocionais e interpessoais crônicos presentes nesse tipo de trabalho (MASLACH et al., 2001). A Classificação Internacional de Doenças (CID - 10) classifica, sob o código Z73.0: estado de exaustão vital, os problemas relacionados com a organização do modo de vida e, sob o código Z56, os problemas relacionados com o emprego e o desemprego, entre os quais as dificuldades físicas e mentais relacionadas ao trabalho.

No Brasil, a Lista de Doenças Relacionadas com o Trabalho do Ministério da Saúde classifica o burnout, ou síndrome do esgotamento profissional, entre os Transtornos Mentais e do Comportamento Relacionados com o Trabalho.

MASLACH et al. (2001), em artigo de revisão, relatam que a pesquisa sobre burnout ocorreu inicialmente em países de língua inglesa, como Canadá e Grã-Bretanha e, posteriormente, surgiram artigos, livros e pesquisas em numerosos idiomas na Europa e em Israel. Nessa revisão os autores observam que o conceito estava sendo estudado em diversas nações em todo o mundo e que o termo burnout, proveniente da linguagem coloquial, muitas vezes foi deixado sem tradução, mesmo em países onde existe sua tradução literal como Alemanha, Holanda, Suécia e Noruega. 
Em sua análise sobre os 35 anos de estudos sobre burnout, SCHAUFELI et al. (2009) observam que após emergir nos EUA nos anos 70, o conceito de burnout foi introduzido nos anos 80 no Oeste Europeu (Reino Unido, Holanda, Bélgica, Alemanha, Escandinávia e Finlândia) e em Israel. Em meados dos anos 90 o burnout estava sendo estudado no Leste Europeu, Ásia, Oriente Médio, América Latina, Austrália e Nova Zelândia e, após a virada do século, a pesquisa sobre o assunto ganhou espaço na África, China e Índia.

SCHAUFELI et al. (2009) avaliam que a expansão da pesquisa sobre burnout no mundo se dá ao passo da transformação da sociedade industrial para uma economia voltada à prestação de serviços, e discutem o contexto de pressões psicológicas decorrentes da mudança ocorrida no mundo do trabalho. Consideram que o burnout (e seu estudo) é um fenômeno global, ainda que sua definição não seja exatamente a mesma em todas as culturas, assim como variam as consequências de seu diagnóstico conforme os modelos de seguridade social vigentes nos países.

$\mathrm{Na}$ visão desses autores (SCHAUFELI et al., 2009), o interesse pela conceitualização, aferição e intervenção quanto ao burnout seria uma consequência do desenvolvimento econômico das nações. O desenvolvimento acelerado em países como a Índia, por exemplo, elevando a demanda pela aprendizagem de novas habilidades, necessidade de novos tipos de trabalho e gerando pressão por alta produtividade, qualidade e por rapidez são entendidos como processos inerentes à mudança no modelo macroeconômico e que, ao mesmo tempo, geram burnout.

A partir dos estudos iniciais, conduzidos na década de 70, o conhecimento baseado em pesquisas sobre burnout tem se ampliado. Em revisão realizada em 2009, SCHAUFELI et al. avaliaram que já havia mais de 6.000 livros, capítulos, dissertações e artigos científicos publicados sobre burnout no mundo. 


\subsection{Burnout ou síndrome do esgotamento profissional - grupos mais afetados}

MASLACH et al. (2001) relatam que a pesquisa em burnout se fundamentou na experiência de pessoas trabalhando em serviços da área social e em cuidados de saúde; ocupações em que o serviço é oferecido a pessoas necessitadas, sendo um trabalho que pode ser caracterizado por estressores emocionais e interpessoais. Esses autores referem que os primeiros trabalhos foram escritos por Freudenberger em 1975 e por Maslach em 1976 (p. 399).

Freudenberger, psiquiatra americano que trabalhava em uma agência alternativa de cuidados de saúde, escreveu sobre a percepção em si mesmo e em seus colegas de exaustão emocional, perda de motivação e falta de envolvimento com o trabalho. Ele empregou um termo usado coloquialmente para referir os efeitos do uso crônico de drogas: burnout. O trabalho da psicóloga Maslach, voltado ao estudo das emoções no ambiente de trabalho, iniciou com a realização de entrevistas com grande número de trabalhadores em serviços de cunho assistencial, o que lhe permitiu escrever sobre o estresse emocional relacionado a esse tipo de trabalho além de relatar o desenvolvimento de estratégias de enfrentamento ao desgaste sofrido (MASLACH et al., 2001, p. 400).

Temas específicos ao burnout emergiram das entrevistas de Maslach: primeiramente ficou claro que a provisão de serviço ou cuidado pode demandar intensamente e que a exaustão emocional não é uma resposta incomum à sobrecarga de trabalho. Os aspectos relacionados à despersonalização (entendida como distanciamento emocional) também foram descritos a partir dessas entrevistas. Maslach observou que o distanciamento constitui uma estratégia de autoproteção e tentativa de manterse "funcionando" no serviço prestado, podendo levar a atitudes negativas, insensíveis e até desumanizadas. Por sua vez a terceira dimensão da síndrome: sentimento de baixa realização profissional ou de pouco envolvimento pelo trabalho, surgiu por meio da atenção a aspectos não verbais observados nas entrevistas (MASLACH et al., 2001). 
Segundo MASLACH et al.(2001), desde o início, o burnout tem sido discutido à luz de duas perspectivas: a perspectiva clínica o discute em termos dos sintomas relacionados a este agravo; e a perspectiva da psicologia social que discute o burnout em termos das inter-relações entre provedor e receptor de cuidados, no contexto situacional das ocupações assistenciais e de prestação de serviços.

Em seu estudo, Maslach observou que estão sujeitos ao burnout os profissionais que atuam em ocupações em que o cerne do trabalho é o relacionamento entre provedor e receptor, isto é, ocupações relacionadas a cuidados assistenciais e à prestação de serviços, como: professores, assistentes sociais, policiais, psicólogos, médicos, entre outras (MASLACH et al., 2001).

\subsection{Prevalência de burnout entre professores}

Os professores representam categoria vulnerável à síndrome de esgotamento profissional (burnout). Pesquisadores, em contextos diversos, observam a ocorrência de sintomas físicos e emocionais nessa categoria (ARAÚJO e CARVALHO, 2009; GASPARINI et al., 2006) e os estudos associam tais sintomas ao burnout (BELCASTRO e GOLD, 1983; ZHONG et al., 2009).

Um dos instrumentos mais utilizados para aferir burnout é o Maslach Burnout Inventory (MBI), desenvolvido por MASLACH e JACKSON (1981, 1986, 2010). Trata-se de um questionário de 22 itens que possui uma versão para profissionais de saúde, uma para educadores e outra para profissionais em geral. Autores referem que o MBI apresenta propriedades psicométricas que têm se preservado em suas traduções e validações para numerosos idiomas (GARCIA e BENEVIDESPEREIRA, 2003; MASLACH et al., 2001).

Em revisão sistemática dirigida a estudos que avaliaram a prevalência de burnout em professores, SANTOS e NASCIMENTO SOBRINHO (2011) selecionaram 1.244 artigos publicados em português, inglês ou espanhol, entre 1989 e 2009. 
Considerando, entre outros critérios, a utilização do MBI para aferição de burnout entre professores, os autores selecionaram para análise 35 estudos provenientes dos seguintes países: Alemanha, Argentina, Austrália, Brasil, Chipre, China (Hong Kong), Colômbia, E.U.A., França, Grécia, Holanda, México, Peru, Portugal, Turquia e Venezuela.

Nesta revisão, SANTOS e NASCIMENTO SOBRINHO (2011) relatam que os resultados do MBI variaram entre os estudos, e ponderam sobre a dificuldade de uma análise comparativa considerando a influência de fatores históricos, geográficos, sociais, econômicos e culturais. Quanto à interpretação dos resultados do MBI, os autores apontam que alguns estudos definiram burnout pela presença em nível alto das três dimensões investigadas pelo inventário (exaustão emocional, despersonalização e baixa realização profissional), enquanto outros trabalhos aceitaram a presença de apenas uma dimensão em nível alto para defini-lo.

Estes pesquisadores (SANTOS e NASCIMENTO SOBRINHO, 2011) reportam que parte dos estudos apresentou os resultados das três dimensões do MBI em porcentagens que variaram entre 5,0\% a 45,8\% na dimensão Exaustão Emocional; $3,0 \%$ a 32,0\% na dimensão Despersonalização e de 12,4\% a 45,0\% em Baixa Realização Profissional. Observam também que uma parte dos estudos apresentou os resultados do MBI como variáveis categóricas (alto, moderado e baixo), para afirmar se a síndrome está presente ou não; enquanto outra parte dos estudos apresentou os resultados em médias para cada uma das dimensões investigadas pelo teste.

Estes autores (SANTOS e NASCIMENTO SOBRINHO, 2011) ainda relatam que os estudos que utilizaram médias para apresentação dos resultados trabalharam com os valores do MBI como variáveis quantitativas, calculando a média dos resultados individuais e comparando-os com a média da população ou amostra estudada. A média relativa à dimensão Exaustão Emocional (EE) variou de 0,9 a 5,4 e a relativa à Despersonalização (De) variou de 0,8 a 2,0; sendo considerado o resultado superior à média da população amostral nessas dimensões (EE e De) como indicativo de burnout. Na dimensão Baixa Realização Profissional (BRP), a média variou de 0,6 a 
9,0; sendo considerado o valor abaixo da média como indicativo de burnout.

A partir dos estudos que analisaram, SANTOS e NASCIMENTO SOBRINHO (2011) concluíram que ocorre elevada prevalência de burnout entre professores de ensino fundamental e médio e observaram crescimento da pesquisa sobre o burnout entre professores.

\subsection{Investigação de burnout e confiabilidade do MBI}

O MBI é um dos instrumentos mais utilizados na aferição de burnout no mundo. Seu uso se expandiu a vários contextos culturais nos diversos continentes, além de ter estimulado a construção de outros instrumentos para investigação da síndrome. $\mathrm{O}$ fato de ter sido validado em diversos idiomas possibilita alguma comparabilidade entre os resultados aferidos, como realizado no estudo feito por LUK et al. (2010), que compara os resultados do MBI obtidos em Macau, Hong Kong e E.U.A.

Por outro lado, a forma de interpretação e apresentação dos resultados do MBI não possui padrão único. AGUAYO et al. (2011) realizaram metanálise dirigida ao estudo da confiabilidade, ou fidedignidade, das diversas validações do questionário no mundo. A partir de várias bases de dados, os pesquisadores buscaram apenas os estudos empíricos utilizando o MBI que reportaram o coeficiente alfa da amostra, obtendo 84 estudos. Dentre estes, selecionaram 45 trabalhos - que correspondem a 51 amostras e a 25.337 participantes, dos quais $46,5 \%$ eram professores. $\mathrm{Na}$ metanálise dos estudos selecionados, AGUAYO et al. (2011) investigaram a influência na variância da confiabilidade estimada (alfa de Cronbach) em relação às variáveis: idade, sexo, tipo de população (professores, profissionais de saúde ou outros), tamanho da amostra, idioma do teste, amostra probabilística ou não, países/região em que foi realizado o estudo, entre outras e apresentaram os resultados relativos a cada dimensão do MBI.

Na escala de Exaustão Emocional, AGUAYO et al. (2011) consideraram alto o 
índice de heterogeneidade obtido, o que relacionaram à influência de variáveis como a região em que o estudo foi feito: estudos realizados na América do Norte reportaram coeficiente de confiabilidade mais alto $(\alpha=0,91)$ que os da Europa $(\alpha=$ $0,87)$ e de outras regiões $(\alpha=0,86)$.

Outras variáveis que apresentaram diferença estatisticamente significante na variância dos coeficientes de confiabilidade da escala de Exaustão Emocional foram: - tipo da amostra: probabilística $(\alpha=0,90)$, não probabilística $(\alpha=0,87)$;

- média de idade da amostra: quanto maior a média de idade, maior o coeficiente de confiabilidade;

- variável idioma: estudos em inglês apresentaram confiabilidade mais alta $(\alpha=0,90)$, espanhol $(\alpha=0,87)$ ou outros $(\alpha=0,87)$;

- e tipo de MBI: original $(\alpha=0,90)$, adaptado $(\alpha=0,87)$.

Na escala Despersonalização, as variáveis que apresentaram diferença significante na variância dos coeficientes de confiabilidade foram:

- idioma: inglês $(\alpha=0,76)$, outros idiomas $(\alpha=0,69)$ e espanhol $(\alpha=0,60)$;

- tipo de MBI: original $(\alpha=0,76)$ adaptado $(\alpha=0,64)$;

- e a variável região onde foi feito o estudo: América do Norte $(\alpha=0,76)$, Europa ( $\alpha=$ $0,68)$, outras regiões $(\alpha=0,63)$.

Na escala Envolvimento Pessoal não foi encontrada diferença significante em relação a nenhuma variável moderadora.

AGUAYO et al. (2011) discutem que seus resultados são congruentes com o fato de que a confiabilidade é uma propriedade do escore obtido quando um instrumento de mensuração é aplicado em uma amostra específica, e não uma característica intrínseca do instrumento (Crocker and Algina 1986 e Thompson and Vacha-Haase 2000, citados por AGUAYO et al., 2011, p. 354). Desse modo, desaconselham a prática de indução de confiabilidade, propondo que os estudos empíricos indiquem a confiabilidade obtida em cada dimensão, de acordo com a amostra utilizada, para evitar erros de precisão de estimativa na mensuração de burnout. 


\subsection{MBI no Brasil}

O MBI original foi construído considerando três dimensões relacionadas à síndrome: esgotamento emocional, despersonalização e baixa realização profissional ou falta de envolvimento com o trabalho. Os itens referentes à investigação dessas dimensões são apresentados em escala de formato Likert com 7 graus para resposta relativa à frequência, variando de 0 (nunca) a 6 (sempre) (MORENO-JIMENEZ et al., 2002).

TRINDADE e LAUTERT (2010) referem que o MBI traduzido para o português e validado por Lautert em 1995 apresenta a escala Likert com 7 graus para aferição de frequência. Segundo TRINDADE e LAUTERT (2010, p. 276) essa versão, aplicada a profissionais de saúde, alcançou os seguintes valores alfa de Cronbach: $\alpha=0,86 \mathrm{em}$ Desgaste Emocional; $\alpha=0,69$ em Despersonalização e $\alpha=0,76$ em Realização Profissional.

CARLOTTO e CÂMARA (2004) realizaram análise fatorial da versão de Lautert para o MBI optando, porém, pela utilização da escala Likert com 5 graus de frequência, variando de 1 (nunca) a 5 (diariamente). Nesse trabalho CARLOTTO e CÂMARA (2004) apresentaram os seguintes valores alfa de Cronbach: $\alpha=0,88 \mathrm{em}$ Exaustão Emocional, $\alpha=0,58$ em Despersonalização e $\alpha=0,82$ em Baixa Realização Profissional.

Segundo CARLOTTO e CÂMARA (2004), a adaptação brasileira do MBI realizada por Tamayo em 1997 também optou por reduzir de 7 para 5 os graus da escala Likert para investigação de frequência em cada um dos 22 itens do inventário.

CARVALHO (1995) propõe versão do MBI utilizada para investigação de burnout em amostra de 465 professores da rede pública de sete municípios da Delegacia de Ensino de Mogi Mirim, localizados na região sudoeste do Estado de São Paulo. A autora relata ter realizado os mesmos passos utilizados na construção do MBI original: aplicou o inventário com duas escalas: uma de intensidade e uma de frequência, para aferir a ocorrência de correlação entre as mesmas e, com segurança, 
poder indicar o uso apenas da escala de frequência. CARVALHO, 1995, realizou análise fatorial onde confirmou a adequação de sua versão à mensuração dos constructos: Exaustão Emocional, Despersonalização, Realização Pessoal e Envolvimento (esta última é uma dimensão opcional do inventário de Maslach, avalia aspectos do envolvimento do professor com seu aluno). A análise fatorial desses quatro constructos foi feita para as escalas de intensidade e frequência tendo sido observada alta correlação entre as duas escalas, permitindo afirmar a semelhança entre elas. Além dessas ações, foi verificada a consistência interna ou verificação de fidedignidade, apresentando os seguintes valores alfa de Cronbach: $\alpha=$ 0,84 em Exaustão Emocional; $\alpha=0,64$ em Despersonalização e $\alpha=0,91 \mathrm{em}$ Realização Pessoal. Os resultados de fidedignidade obtidos foram comparados aos de Iwanick (1981) e Gold (1984), citados por CARVALHO (1995, p.123). A autora ainda refere verificação da validade do MBI a partir de critérios externos, por meio de análise fatorial "oneway". Relata que os fatores que apresentaram relação estatisticamente significante foram: sexo, escolaridade, séries em que leciona, número de escolas em que leciona, localização das escolas, número de filhos, possibilidade de progresso profissional, intenção de mudar de profissão e falta dia.

CARVALHO (1995) relata também associação estatisticamente significante das dimensões do MBI com as variáveis: ter autonomia; muita exigência burocrática; muita interferência de especialistas (especialistas da educação: coordenadores, diretores, etc.); muito trabalho extraclasse; classes numerosas e estar satisfeito com o trabalho que realiza.

Na Tabela 1 estão resumidos os valores alfa de Cronbach referidos pelos estudos de versões brasileiras do MBI. 
Tabela 1. Versões brasileiras do $\mathrm{MBI}$ e seus valores de fidedignidade a de Cronbach.

\begin{tabular}{l|c|c|c}
\hline & $\begin{array}{c}\text { Exaustão } \\
\text { Emocional }\end{array}$ & $\begin{array}{c}\text { Desperso- } \\
\text { nalização }\end{array}$ & $\begin{array}{c}\text { Baixa Realização } \\
\text { Profissional }\end{array}$ \\
\hline Lautert, 1995 & 0,86 & 0,69 & 0,76 \\
Carlotto e Câmara, 2004 & 0,88 & 0,58 & 0,82 \\
Carvalho, 1995 & 0,84 & 0,64 & 0,91 \\
\hline
\end{tabular}

\subsection{Instrumentos para avaliação de burnout em professores}

A Tabela 2 compara os resultados obtidos em investigações do MBI realizadas na Espanha, Holanda, Portugal e EUA, segundo Lautert, citada por CARLOTTO e CÂMARA (2004). A subescala Despersonalização apresenta fidedignidade mais baixa nas diferentes investigações, exceto quando aplicada no idioma em que foi construída. Por outro lado, a subescala Baixa Realização Profissional apresenta fidedignidade mais alta em outros idiomas do que em inglês (p. 503).

Tabela 2. Consistência interna do MBI - Teste a de Cronbach. Comparação transcultural.

\begin{tabular}{|l|c|c|c|}
\hline & $\begin{array}{c}\text { Exaustão } \\
\text { Emocional }\end{array}$ & $\begin{array}{c}\text { Baixa Realização } \\
\text { Profissional }\end{array}$ & Despersonalização \\
\hline Espanha* & 0,89 & 0,80 & 0,63 \\
Holanda* & 0,90 & 0,82 & 0,66 \\
EUA* & 0,90 & 0,71 & 0,79 \\
Portugal* & 0,82 & 0,94 & 0,67 \\
Carlotto e Câmara* & 0,88 & 0,82 & 0,58 \\
CARVALHO, 1995 & 0,84 & 0,91 & 0,64 \\
\hline
\end{tabular}

* Dados referidos por CARLOTTO e CÂMARA, 2004 (p.503).

GIL-MONTE et al. (2010) realizaram estudo de validação brasileira do inventário espanhol para avaliação de burnout: Cuestionario para la Evaluación del Síndrome 
de Quemarse por el Trabajo (CESQT). GIL-MONTE et al. (2010) observaram que pesquisadores como Kristensen et al. apontaram insuficiências psicométricas no MBI, sobretudo quando o inventário foi adaptado para outros idiomas excluindo o inglês (p. 141). Os autores consideraram que tais insuficiências justificam a construção de instrumentos alternativos, como o inventário CESQT desenvolvido na Espanha por GIL-MONTE (2008); e argumentaram que o CESQT obteve resultados adequados de validade fatorial e consistência interna na Argentina, Chile e México (GIL-MONTE et al., 2010).

A versão do CESQT validada no Brasil é um instrumento para avaliação de burnout específico para profissionais da educação. GIL-MONTE et al. (2010) relatam que o CESQT guarda similaridades com o MBI, mas apresenta uma escala a mais para avaliação da síndrome, totalizando quatro dimensões: Ilusão pelo Trabalho (relativa a expectativas em relação a este); Desgaste Psíquico; Indolência e Culpa. Em outro estudo, GIL-MONTE et al. (2005) consideram que com a avaliação de sentimentos de culpa (relacionados ao mau desempenho no trabalho), o questionário permite a observação de diferentes perfis na evolução do burnout e que o CESQT inclui a investigação de aspectos cognitivos e físicos do esgotamento, além dos itens emocionais.

A versão brasileira do CESQT apresenta os seguintes valores de confiabilidade alfa de Cronbach: Ilusão pelo Trabalho $(\alpha=0,83)$; Desgaste Psíquico $(\alpha=0,80)$; Indolência $(\alpha=0,80)$ e Culpa $(\alpha=0,80)$, GIL-MONTE et al. (2010). Na avaliação de equivalência semântica, seus itens obtiveram entre $95 \%$ e $100 \%$ de concordância; segundo seus autores a versão brasileira apresenta validade fatorial e consistência interna adequada para avaliar burnout em professores brasileiros (GIL-MONTE et al., 2010).

\subsection{O trabalho do professor e o contexto pedagógico no Brasil}

Em sua análise de estudos desenvolvidos no Brasil sobre as condições de saúde do 
professor, SOUZA e LEITE (2011) remetem à sistematização de Esteve sobre o conjunto de dificuldades e constrangimentos profissionais que afetam os professores. Segundo SOUZA e LEITE (2011, p. 1109), Esteve teoriza o "mal-estar docente" como um fenômeno social, que possui como agentes desencadeadores a desvalorização, concomitante a constantes exigências profissionais; a violência; a indisciplina, entre outros fatores promotores de uma crise de identidade em que o professor passa a se questionar sobre sua escolha profissional bem como questionar o próprio sentido da profissão. Esteve reconhece a ocorrência de burnout entre docentes e ressalta o descompasso entre as mudanças na sociedade brasileira e a incapacidade do sistema educacional de se adequar a elas

SOUZA e LEITE (2011) analisaram pesquisas, teses e dissertações produzidas entre 1997 e 2006 sobre trabalho e saúde da categoria docente no Brasil. Esses autores apontam que, apesar da categoria docente ser quantitativamente expressiva e de sua importância para o desenvolvimento social, os estudos sobre as condições de trabalho e saúde dos professores brasileiros são relativamente recentes quando comparados aos estudos dedicados a outras categorias profissionais. Os autores defendem a análise da organização do trabalho docente como questão central para o tema saúde do professor e elencam diversos aspectos relativos à organização desse trabalho a serem considerados, para que se proteja a categoria das principais morbidades a que está sujeita, entre elas, o burnout.

Um ponto interessante na sistematização de SOUZA e LEITE (2011, p. 1113) é a distinção, estabelecida a partir da bibliografia pesquisada, entre estresse e burnout. Segundo os autores, estudos como o de Codo descrevem que o estresse se refere ao indivíduo, sendo um esgotamento pessoal que afeta sua vida, mas que não está necessariamente vinculado às questões do trabalho. O burnout, entretanto, afeta os envolvidos na situação de trabalho podendo atingir suas relações pessoais. O burnout implica, sobretudo, em atitudes negativas em relação aos usuários, à organização e ao trabalho, envolvendo atitudes e sentimentos que acarretam problemas ao trabalhador e à organização (CODO, 2002). As definições apresentadas pelo conjunto de pesquisas analisadas por SOUZA e LEITE (2011) sintetizam o burnout como 
expressão que designa o sofrimento por exaustão física ou emocional provocado por contínua exposição a situações estressantes no trabalho. Segundo Carvalho, citado por SOUZA e LEITE (2011, p. 1115), entrar em burnout significa chegar ao limite da resistência física ou emocional, sendo que a síndrome se manifesta nas seguintes situações: 1. quando as demandas de trabalho são maiores que as possibilidades humanas e materiais, o que gera um estresse laboral no indivíduo; 2. quando há evidências sobre o esforço de adaptação e produção de respostas emocionais aos desajustes percebidos; e 3. quando há enfrentamento defensivo das tensões experimentadas, ocasionando distanciamento emocional, retirada, cinismo e rigidez. A síndrome pode se manifestar em dores de cabeça, alterações gastrointestinais, fadiga crônica ou exaustão física, tensão muscular, ansiedade, depressão, distúrbios do sono, irritabilidade (SOUZA e LEITE, 2011).

A queixa de sintomas físico-emocionais entre professores costuma ser frequente e, vinculadas a tais sintomas, costumam ser trazidas questões relativas ao trabalho. São frequentes os relatos acerca de agressividade, desrespeito e ameaças por parte de alunos e de pais, situações a que os professores se veem expostos na rotina escolar. Eles também se ressentem de hostilidade da parte de colegas, funcionários administrativos, assistentes de direção e diretores. Em estudo epidemiológico entre professores de Porto Alegre - RS, CARLOTTO e PALLAZO (2006) avaliaram burnout utilizando o MBI e referiram associação entre exaustão emocional e fatores relacionados ao trabalho: carga horária e quantidade de alunos atendidos. As autoras também relataram que as variáveis: mau comportamento dos alunos, expectativas familiares e pouca participação nas decisões institucionais foram os fatores de estresse que apresentaram associação com as dimensões de burnout na população estudada.

A partir dos diversos estudos analisados (CODO, 2002; CARLOTTO e PALLAZO, 2006; SOUZA e LEITE, 2011), consideramos que nas escolas públicas do Brasil parece ocorrer um tipo de violência, de conotações estruturais, onde o educador se apresenta como alvo, sem chance de defesa, frente a alunos que agem como se agredir ou desrespeitar os funcionários da escola fossem comportamentos próprios ao 
contato com a instituição escolar. PEREIRA (2003) aponta a falta de humanização nas relações entre funcionários, alunos e pais e também a falta de projeto político pedagógico para superar tais dificuldades.

Nesse contexto, alunos e seus pais parecem depositar nos representantes da instituição pública um tipo de revolta e uma atitude de oposição de origem pouco definida. Os funcionários da educação parecem pouco preparados para lidar com essas demandas e uma das consequências de seu despreparo pode consistir em distanciamento e negatividade, atitudes defensivas associadas ao burnout. Pesquisa nesse sentido foi realizada na Inglaterra (HALL et al., 1997) mostrando que a questão da humanização dos relacionamentos nas escolas não é um problema apenas em nosso contexto cultural.

Podemos considerar que no Brasil os professores estão sujeitos aos fatores tipicamente relacionados ao desenvolvimento de burnout (em função da natureza desse trabalho relacionado ao cuidado e à assistência interpessoal), como também estão sujeitos aos fatores relativos às mudanças estruturais ocorridas no modelo pedagógico brasileiro, além dos aspectos relacionados à violência urbana no país. Frequentemente são divulgados casos dramáticos, como o da professora da cidade de Marília, no interior do Estado de São Paulo que, em junho de 2012, teve um AVC (acidente vascular cerebral) enquanto alunos depredavam seu carro estacionado na escola $^{* 1, * 2}$. Os diversos casos de professores agredidos dentro da escola, assim como o da professora de São Caetano do Sul - $\mathrm{SP}^{* 3}$, *4, que levou um tiro de um aluno, sem qualquer motivo aparente, parecem ilustrar os extremos de desumanização assumidos

\footnotetext{
${ }^{* 1}$ Disponível em: http://g1.globo.com/sp/bauru-marilia/noticia/2012/06/professora-sofre-derrameapos-ato-de-vandalismo-de-alunos-em-marilia.html Acessado em 20.02.2013.

${ }^{* 2}$ Disponível em:http://www.diariodemarilia.com.br/Noticias/112942/Professora-vtima-de-AVCdeixa-UTI-aps-26-dias Acessado em 20.02.2013.

*3 Disponível em: http://g1.globo.com/sao-paulo/noticia/2011/09/aluno-atira-em-professora-dentro-dasala-de-aula-no-abc.html Acessado em 20.02.2013.

${ }^{*}$ Acessado em 20.02.2013. Disponível em: http://noticias.uol.com.br/cotidiano/ultimasnoticias/2011/09/22/escola-que-foi-palco-de-disparos-em-sao-caetano-do-sul-sp-e-a-melhor-de-saopaulo-no-ideb.htm
} 
em certos momentos por partícipes da educação pública. É certo que, proporcionalmente, pouquíssimos professores serão tão violentamente agredidos por seus alunos, entretanto o fato de serem desrespeitados sistematicamente e isto ser encarado como "natural" exige reflexão. Além disso, que tipo de impacto o desrespeito e a agressividade, aparentemente implícitos no contexto educacional, tem no professor? Esse profissional cujo preparo é voltado ao cuidar está preparado para lidar também com o desrespeito do qual tem sido alvo cotidianamente? O professor pode ser mais bem preparado para o desafio de estimular o aprendizado em condições tão adversas?

\subsection{Burnout entre professores da rede pública municipal de São Paulo}

Na cidade de São Paulo, em fevereiro de 2013, são referidos 83.243 servidores da Secretaria Municipal de Educação ${ }^{* 5}$, destes, 29.572 são professores do ensino fundamental e 24.463 são professores de educação infantil, somando 54.035 professores distribuídos em 1.452 escolas sob a administração municipal direta. Segundo a Secretaria de Educação ${ }^{* 6}$ : "a rede municipal de ensino da cidade de São Paulo é o maior sistema do país, com quase 1 milhão de alunos, 8,8\% dos 11,3 milhões de habitantes da cidade. Somados aos pais e familiares, envolve quase cinco milhões de pessoas, ultrapassando, e muito, a população da maioria das capitais brasileiras".

Perante a magnitude dos números relacionados à educação pública municipal em São Paulo, surpreende o fato de não serem encontrados estudos dirigidos à mensuração de burnout entre seus professores.

\footnotetext{
${ }^{*}$ Portal da Secretaria Municipal de Educação de São Paulo, Educação em Números, Mais Números da Secretaria, Total Servidores por Área de Atuação, acessado em 16/02/2013. Disponível em: http://eolgerenciamento.prefeitura.sp.gov.br/frmgerencial/NumerosCoordenadoria.aspx?Cod=000000

${ }^{* 6}$ Portal da Secretaria Municipal de Educação de São Paulo, Educação em Números, acessado em 16/02/2013. Disponível em: http://www.portalsme.prefeitura.sp.gov.br/AnonimoSistema/BannerTexto.aspx?MenuBannerID=22
} 
Considerando que o estudo de aspectos de saúde dos professores em relação ao contexto do trabalho docente nas escolas públicas pode ampliar o conhecimento dos fatores associados ao burnout entre esses profissionais, e colaborar para a discussão e melhor adequação de seu contexto ocupacional; este estudo avaliou a ocorrência de burnout em professores da rede pública do município de São Paulo, com indicação de atendimento em saúde mental e usuários do Hospital do Servidor Público Municipal (HSPM), analisando a ocorrência de burnout nessa população em relação à: aspectos de saúde, fatores sócio ocupacionais, incluindo a investigação de aspectos relacionados à violência dentro e fora das salas de aula. 


\section{OBJETIVOS}

\subsection{Objetivo Geral}

O objetivo geral foi estudar aspectos de saúde e de condições de trabalho e a ocorrência de burnout, avaliado segundo instrumentos específicos, entre professores da rede pública do município de São Paulo, com indicação de tratamento psicoterápico e usuários do Hospital do Servidor Público Municipal (HSPM).

\subsection{Objetivos Específicos}

2.2.1. Utilizando questionário sociodemográfico-ocupacional e entrevista semiestruturada investigar: o contexto organizacional em que estão inseridos os professores; aspectos relacionados à saúde e a licenças médicas; e aspectos relacionados à violência e agressividade nos contatos dentro e fora da escola.

2.2.2. Identificar a ocorrência de burnout entre professores municipais com indicação, ou em início, de atendimento psicológico no HSPM, utilizando os inventários MBI e CESQT.

2.2.3. Comparar entre si os resultados obtidos nos inventários de mensuração de burnout (MBI e CESQT) e analisar seus resultados em relação às variáveis sociodemográficas e ocupacionais. 


\section{MÉTODOS}

\subsection{População de estudo}

Professores da rede municipal de São Paulo que buscam atendimento psicológico no HSPM. Os critérios de inclusão para o estudo foram:

- Professores com indicação ou em início de atendimento psicológico

- Professores ativos ou em licença

- Professores readaptados, ativos ou em licença

- Professores aposentados por motivos médicos

- Concordância em participar da pesquisa, assinando o termo de consentimento livre e esclarecido (Anexo1).

Foram excluídos do estudo os servidores nas seguintes condições:

- Professores aposentados por tempo de serviço

- Servidores em outras funções relacionadas à Secretaria da Educação (agente escolar, diretor, coordenador pedagógico, auxiliares administrativos, etc.).

\subsection{Amostra}

Participaram da pesquisa 76 professores, sendo assegurado o acompanhamento psicológico aos usuários do serviço independentemente da concordância em participar do estudo.

\subsection{Definição de caso}

De acordo com as indicações propostas por seus autores (GIL-MONTE et al., 2010), os itens do CESQT foram avaliados mediante uma escala de frequência de cinco pontos, de 0 (Nunca) a 4 (Muito frequente: todos os dias), tendo como ponto 
intermediário a pontuação 2 (“Às vezes: algumas vezes por mês"). Cada subescala é calculada pela média da pontuação dos itens que a integram. Baixas pontuações na Ilusão pelo trabalho $(<2)$ e altas pontuações em Desgaste Psíquico, Indolência e Culpa ( $\geq 2)$ supõe altos níveis da síndrome de burnout.

O Maslach Burnout Inventory - Educators Survey (MBI-ES), inventário para avaliação de burnout em professores, foi traduzido para o português a partir de autorização pelos detentores dos direitos autorais representados por Mind Garden, Inc.; e documentada por meio do Translation Agreement Number TA-346. O MBI utiliza para aferição de burnout primeiramente o cálculo dos escores totais para cada indivíduo em cada uma das subescalas e estabelece pontos de corte para caracterizalos em nível alto, médio ou baixo da síndrome (MASLACH et al., 1986, 2010).

\subsection{Instrumentos}

Para a avaliação dos professores forma utilizados:

1. Inventário MBI-ES, traduzido para o português com autorização de Mind Garden, Inc., para uso exclusivamente em pesquisa sendo expressamente vetada a publicação do material traduzido;

2. Inventário CESQT para avaliação de burnout traduzido e validado no Brasil por Gil-Monte et al., 2010 (Anexo 2);

3. Entrevista semiestruturada desenvolvida para acolhimento, caracterização e elaboração das queixas motivadoras da procura de atendimento psicológico pelo professor (Anexo 3).

4. Questionário de caracterização sociodemográfica e ocupacional (Anexo 4);

\subsection{Características da escola e do indivíduo}

Esses aspectos foram abordados por meio de questionário específico (Anexo 4), o qual incluiu variáveis relacionadas a: 
Aspectos sociodemográficos:

- Identificação (sexo, idade, estado civil)

- Local de residência e de trabalho

- Renda familiar

- Atividades de laser e entretenimento

Aspectos ocupacionais e motivacionais:

- Tempo de serviço como professor

- Jornada semanal como professor

- Jornada semanal em outra atividade além da docência

- Motivação pelo trabalho

- Interesse por outro tipo de trabalho

Ambiente físico da escola e das salas de aula:

- Nível de iluminação na sala de aula

- Nível de limpeza na sala de aula

- Recursos matérias disponíveis para o trabalho

- Acústica da sala de aula

- Nível de ruído na escola e na sala de aula

- Presença de lugar para descanso na escola

- Observações quanto ao ambiente de trabalho

Contato com os alunos, pais, coordenadores e colegas:

- Número de alunos que atende diariamente

- Percepção de mau comportamento dos alunos

- Sente necessidade de atualização profissional

- Sente sobrecarga de atividades

- Como considera a execução de atividades burocráticas

- Como considera seu contato com seus alunos

- Como considera seu contato com os pais dos alunos 
- Como considera seu contato com a coordenação e com os colegas

- Como considera sua participação em decisões institucionais

Aspectos relacionados à saúde e licenças médicas:

- Problemas de saúde

- Uso de medicamento

- Tratamentos se saúde anteriores e atuais

- Licenças por motivo de saúde anteriores e atuais

Aspectos relacionados à violência, ou agressividade, dentro e fora da escola:

- Episódios de agressividade sofridos fora da escola no último ano

- Percepção de dano físico ou psicológico em função da agressão sofrida

- Episódios agressivos sofridos dentro da escola no último ano

- Percepção de dano físico ou psicológico em função da agressão sofrida na escola

- Episódios agressivos sofridos por outras pessoas dentro ou fora da escola

- Percepção de dano físico ou psicológico em outrem em função da agressão sofrida

\subsection{Análise dos dados}

Os dados primeiramente foram digitados no programa Epidata 3.1 e posteriormente foram feitas análises utilizando o programa Stata, versão 13.0.

Foram realizadas análises descritivas dos dados. As associações estatísticas foram investigadas por meio dos testes Qui-quadrado e Exato de Fisher.

\subsection{Questões Éticas}


Esta pesquisa está cadastrada na Plataforma Brasil, CAAE: 12684613.5.0000.5421, tendo sido aprovada pelo Comitê de Ética em Pesquisa da Faculdade de Saúde Pública da Universidade de São Paulo e também foi aprovada pelo Comitê de Ética em Pesquisa do Hospital do Servidor Público Municipal. 


\section{RESULTADOS}

\subsection{Caracterização da amostra}

Neste estudo participaram 76 professores, dos quais $92,11 \%$ eram mulheres.

A partir das datas de nascimento foi calculada a idade dos participantes em junho de 2014. A idade apurada variou entre 29 anos e dois meses e 69 anos e 11 meses (média $=47,8$ anos, desvio-padrão $=9,5$ ). A Figura 1 mostra que 65,79\% dos participantes do estudo estavam na faixa de 40 a 59 anos e $11,84 \%$ tinham acima de 60 anos.

Figura 1. Distribuição percentual dos participantes segundo faixas etárias.

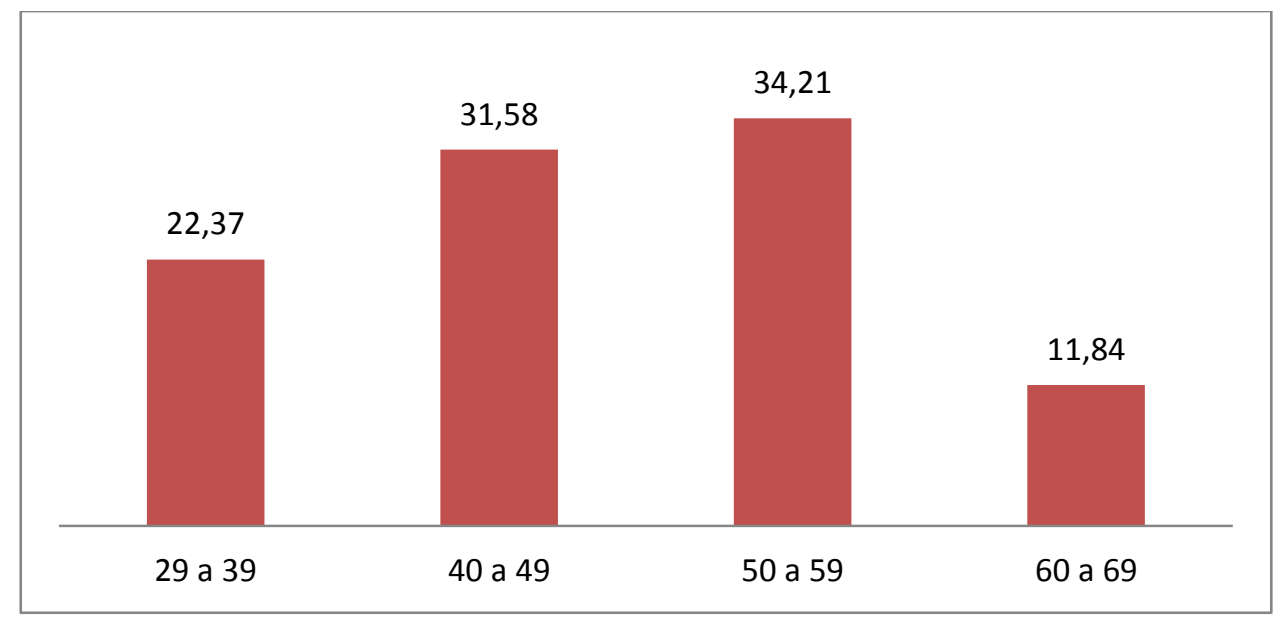

Em relação à escolaridade, foi constatado que 2,63\% dos participantes tinham apenas o curso médio; $51,32 \%$ concluíram formação de nível superior e 46,05\% já haviam concluído pós-graduação à época de sua participação na pesquisa.

Quanto ao local de residência, 38,16\% dos indivíduos residiam na zona Leste da cidade de São Paulo. A mesma proporção de participantes residia na zona Norte e na zona Sul (15,79\% em cada uma). Os moradores da zona Oeste representaram 3,95\% da amostra e os residentes na região Central 1,32\%. 
Participantes residentes em cidades da Grande São Paulo representaram 25\% da amostra, distribuídos em: Guarulhos (5,26\%); São Bernardo do Campo (3,85\%); Osasco (3,95\%); Embu das Artes (2,63\%); e Diadema, Ferraz de Vasconcelos, Itaquaquecetuba, Mauá, Poá, São Caetano do Sul e Suzano (1,32\% em cada uma).

A Tabela 3 mostra a distribuição dos professores em relação à região em que trabalhavam. Uma participante se aposentou do cargo de professora no município de São Paulo, mas mantinha o vínculo de professora na rede estadual de ensino na cidade de Mauá, na Grande São Paulo. Segundo a participante, sua aposentadoria do vínculo no município de São Paulo se relacionou ao desgaste profissional e não ao tempo de serviço, dessa forma ela preenchia os critérios de inclusão estabelecidos.

Tabela 3 - Distribuição dos professores conforme a região em que trabalhavam.

\begin{tabular}{lcc}
\hline Região do local de trabalho & $\mathrm{n}$ & $\%$ \\
\hline Região Leste & 36 & 47,37 \\
Região Sul & 17 & 22,37 \\
Região Norte & 15 & 19,74 \\
Região Oeste & 5 & 6,58 \\
Região Central & 2 & 2,63 \\
Mauá & 1 & 1,32 \\
\hline Total & 76 & 100,00 \\
\hline
\end{tabular}

Em nossa amostra, 44,74\% das pessoas estavam casadas (ou em união estável); $25 \%$ separadas, desquitadas ou divorciadas; $23,68 \%$ estavam solteiras e $6,58 \%$ viúvas.

Quanto ao número de filhos, $25 \%$ dos participantes não tinham filhos à data da pesquisa; $18,42 \%$ tinham apenas um filho; 30,26\% dois filhos; $22,37 \%$ tinham três filhos e três pessoas $(3,95 \%)$ tinham quatro filhos.

Na Tabela 4 encontra-se a distribuição dos participantes de acordo com o número de pessoas com quem residiam. 
Tabela 4 - Distribuição dos professores de acordo com

o número de pessoas com quem residiam.

\begin{tabular}{lcc}
\hline Pessoas na residência & $\mathrm{n}$ & $\%$ \\
\hline 1 & 13 & 17,11 \\
2 & 17 & 22,37 \\
3 & 21 & 27,63 \\
4 & 14 & 18,42 \\
5 ou mais & 11 & 14,48 \\
\hline Total & 76 & 100,00 \\
\hline
\end{tabular}

Entre os 76 participantes, 59,21\% informaram que eram chefes da própria família, $11,84 \%$ consideravam que compartilhavam essa chefia e $28,95 \%$ não se consideravam chefes de suas famílias.

A maioria dos professores relatou a existência de outra renda em sua residência $(72,37 \%)$. A Tabela 5 descreve a procedência da renda que se soma àquela do participante.

Tabela 5 - Origem de outras rendas na residência do professor.

\begin{tabular}{lrr}
\hline Origem da renda & $\mathrm{n}$ & \multicolumn{1}{c}{$\%$} \\
\hline Cônjuge & 32 & 58,18 \\
Filhos & 8 & 14,55 \\
Pais & 4 & 7,27 \\
Cônjuge e filhos & 4 & 7,27 \\
Outros & 3 & 5,45 \\
Irmãos & 2 & 3,64 \\
Pais e irmãos & 1 & 1,82 \\
Pais e cônjuge & 1 & 1,82 \\
\hline Total & 55 & 100,00 \\
\hline
\end{tabular}

A renda líquida da família (soma das rendas da residência com desconto dos impostos) variou entre $\mathrm{R} \$ 2.000,00$ e $\mathrm{R} \$ 11.000,00$, sendo a renda média correspondente a $\mathrm{R} \$ 5.398,68$ com desvio-padrão de $\mathrm{R} \$ 1.935,80$. 
Entre os participantes, três pessoas não referiram práticas relacionadas ao lazer. Os demais participantes citaram diversas atividades, entre estas identificamos cinco tipos ou categorias (Tabela 6). Atividades religiosas foram espontaneamente referidas como lazer e foram consideradas como uma categoria.

Entre os professores que relataram atividade de lazer, 31,51\% referiram a prática de apenas um determinado tipo; 50,68\% indicaram dois tipos de atividades de lazer e $17,81 \%$ indicaram três tipos.

Tabela 6 - Atividades de lazer praticadas pelos professores.

\begin{tabular}{lrr}
\hline Lazer & $\mathrm{n}$ & $\%$ \\
\hline Atividades culturais / dança / viagens / artesanato & 58 & 47,16 \\
Descanso/ tarefas domésticas/ consumo & 21 & 17,07 \\
Atividades de contato interpessoal & 19 & 15,45 \\
Atividades físicas/ visita a parques & 18 & 14,63 \\
Atividades religiosas & 7 & 5,69 \\
\hline Total & 123 & 100,00 \\
\hline
\end{tabular}

\subsection{Aspectos ocupacionals}

Entre os participantes, o mais antigo na carreira docente iniciou em 1972, e em 2010 ingressou o iniciante mais recente.

$\mathrm{Na}$ investigação sobre a situação funcional dos participantes, observamos que $64,47 \%$ deles se encontravam na ativa; $18,42 \%$ estavam em licença médica; $14,47 \%$ estavam readaptados e 2,63\% em licença decorrente de acidente de trabalho (CAT).

A Tabela 7 apresenta a distribuição dos professores conforme a quantidade de anos atuando na educação e a situação funcional dos mesmos no momento da pesquisa.

Ressaltamos que $32,89 \%$ dos professores da amostra tinham mais de 25 anos de 
trabalho na educação e ainda que 30,61\% dos participantes na ativa já estavam trabalhando há mais de 25 como professores.

Tabela 7 - Distribuição dos participantes conforme sua situação funcional e o tempo de atuação na educação.

\begin{tabular}{lccccc}
\hline & Ativo & CAT & Lic. Médica & Readaptado & Total \\
& $\mathrm{n}(\%)$ & $\mathrm{n}(\%)$ & $\mathrm{n}(\%)$ & $\mathrm{n}(\%)$ & $\mathrm{n}(\%)$ \\
\hline + de 25 anos & 15 & 1 & 6 & 3 & 25 \\
de trabalho & $(30,61)$ & $(50,00)$ & $(42,86)$ & $(27,27)$ & $(32,89)$ \\
\multirow{2}{*}{ Menos de 25 } & 34 & 1 & 8 & 8 & 51 \\
anos & $(69,39)$ & $(50,00)$ & $(57,14)$ & $(72,73)$ & $(67,11)$ \\
\hline Total & 49 & 2 & 14 & 11 & 76 \\
& $(100,00)$ & $(100,00)$ & $(100,00)$ & $(100,00)$ & $(100,00)$ \\
\hline
\end{tabular}

$p=0,761$

A Tabela 8 apresenta a relação entre o estado civil dos participantes e seu tempo de atuação na educação. Podemos observar que 44\% dos profissionais com mais de 25 anos na educação estão separados ou divorciados.

Tabela 8 - Relação entre o tempo de atuação na educação e o estado civil dos participantes.

\begin{tabular}{lccc}
\hline & $\begin{array}{c}\text { de } 25 \text { anos de } \\
\text { trabalho } \\
\mathrm{n}(\%)\end{array}$ & $\begin{array}{c}\text { Menos de } 25 \text { anos } \\
\text { de trabalho } \\
\mathrm{n}(\%)\end{array}$ & Total \\
& $8(32,00)$ & $26(50,98)$ & $34(44,74)$ \\
Casado (a) & $11(44,00)$ & $8(15,69)$ & $19(25,00)$ \\
Separado (a) & $4(16,00)$ & $14(27,45)$ & $18(23,68)$ \\
Solteiro (a) & $2(8,00)$ & $3(5,88)$ & $5(6,58)$ \\
Viúvo (a) & $25(100,00)$ & $51(100,00)$ & $76(100,00)$ \\
\hline Total & &
\end{tabular}

$p=0,049$

Observa-se na Tabela 9 que dois professores da pesquisa iniciaram na rede pública municipal no período entre 1972 e 1981. Eles estariam acumulando de 33 a 42 anos de carreira docente apenas no município de São Paulo. Na verdade, esses dois 
participantes se ausentaram da função docente por longos períodos e, no momento da pesquisa, contavam 15 e 21 anos atuando como professores.

\begin{tabular}{|c|c|c|}
\hline Entrada na rede municipal & $\mathrm{n}$ & $\%$ \\
\hline 1972 a 1981 & 2 & 2,63 \\
\hline 1982 a 1991 & 19 & 25,00 \\
\hline 1992 a 2001 & 19 & 25,00 \\
\hline 2002 a 2013 & 36 & 47,37 \\
\hline Total & 76 & 100,00 \\
\hline
\end{tabular}

Quanto ao número de cargos assumidos pelos professores, 50\% da amostra afirmou manter apenas um cargo docente e a outra metade referiu acumular dois cargos.

Cada cargo docente corresponde a um vínculo empregatício e está relacionado a uma determinada jornada de trabalho. No início do ano letivo a Secretaria de Educação do município realiza o processo de escolha, quando os professores municipais escolhem a escola e o tipo de jornada de trabalho que cumprirão semanalmente durante o ano letivo de acordo com o cargo para o qual foram contratados.

Conforme o nível educacional, a jornada pode ser de 20,30 ou 40 horas semanais em cada cargo. A Tabela 10 apresenta a jornada assumida pelos participantes no momento da pesquisa.

A relação entre a jornada semanal e o número de cargos mostra que dentre as 38 pessoas que no momento assumiam apenas um cargo de professor, 52,63\% cumpriam jornada de 30 horas semanais e o restante cumpria jornada de 40 horas.

Os participantes que assumiam dois cargos docentes trabalhavam de 50 a 80 horas semanais na educação, sendo que 57,89\% desse grupo cumpriam 70 horas de jornada semanal. 
Tabela 10 - Distribuição dos participantes conforme a jornada semanal de trabalho.

\begin{tabular}{lrc}
\hline Jornada Semanal & $\mathrm{n}$ & \multicolumn{1}{c}{$\%$} \\
\hline $20 \mathrm{~h}$ & - & \multicolumn{1}{c}{-} \\
$30 \mathrm{~h}$ & 20 & 26,32 \\
$40 \mathrm{~h}$ & 18 & 23,68 \\
20 e $30 \mathrm{~h}(50 \mathrm{~h})$ & 3 & 3,95 \\
30 e $30 \mathrm{~h}(60 \mathrm{~h})$ & 7 & 9,21 \\
20 e $40 \mathrm{~h}(60 \mathrm{~h})$ & 3 & 3,95 \\
30 e $40 \mathrm{~h}(70 \mathrm{~h})$ & 22 & 28,94 \\
40 e $40 \mathrm{~h}(80 \mathrm{~h})$ & 3 & 3,95 \\
\hline Total & 76 & 100,00 \\
\hline
\end{tabular}

Além da jornada, cada cargo docente também corresponde a um nível educacional de assistência (educação infantil, ensino fundamental I, fundamental II e ensino médio) e ainda corresponde a um local de trabalho (EMEI - Escola Municipal Educação Infantil, CEI - Centro de Educação Infantil, CEU - Centro Educação Unificado, EMEF - Escola Municipal de Ensino Fundamental, CIEJA - Centro Integrado de Educação de Jovens e Adultos, entre outros) (Tabela 11).

Observou-se relação entre o número de cargos e o nível educacional em que atuam os participantes: $51,32 \%$ da amostra atendiam à educação infantil e, dentre estes, $64,10 \%$ mantinham apenas um cargo docente.

O levantamento da jornada semanal de trabalho incluiu os vínculos dos professores com a rede municipal e com a rede estadual de ensino, assim como considerou as contratações em escolas particulares.

Observamos que $89,47 \%$ dos participantes mantinham vínculo docente exclusivamente com a rede pública municipal; cinco professores $(6,58 \%$ da amostra) mantinham vínculo com o município e também com a rede estadual de ensino; dois indivíduos $(2,63 \%)$ tinham um vínculo municipal e um vínculo em escola particular e um participante $(1,32 \%)$ mantinha-se apenas na rede estadual de ensino, no momento 
da pesquisa.

Tabela 11 - Distribuição da amostra segundo o nível educacional atendido e o número de cargos assumidos pelos professores.

\begin{tabular}{lrrrrrr}
\hline \multirow{2}{*}{ Nível } & \multicolumn{2}{c}{$\begin{array}{c}\text { Um cargo } \\
\mathrm{n}(\%)\end{array}$} & \multicolumn{2}{c}{$\begin{array}{c}\text { Dois cargos } \\
\mathrm{n}(\%)\end{array}$} & \multicolumn{2}{c}{ Total } \\
& \multicolumn{2}{c}{$\mathrm{n}(\%)$} \\
\hline Educação Infantil & 25 & $(65,79)$ & 14 & $(36,84)$ & 39 & $(51,32)$ \\
Fundamental I & 5 & $(13,16)$ & 3 & $(7,89)$ & 8 & $(10,53)$ \\
Fundamental II & 6 & $(15,79)$ & 7 & $(18,42)$ & 13 & $(17,11)$ \\
Ensino Médio & 1 & $(2,63)$ & - & - & 1 & $(1,32)$ \\
Educ. Infantil e Fund. I & - & - & 5 & $(13,16)$ & 5 & $(6,58)$ \\
Educ. Infantil e Fund. II & - & - & 3 & $(7,89)$ & 3 & $(3,95)$ \\
Fundamental I e II & 1 & $(2,63)$ & 4 & $(10,53)$ & 5 & $(6,58)$ \\
Ed. Infantil, Fund. I e II & - & - & 2 & $(5,27)$ & 2 & $(2,63)$ \\
\hline Total & 38 & $(100,00)$ & 38 & $(100,00)$ & 76 & $(100,00)$ \\
\hline
\end{tabular}

$p=0,011$

Além do trabalho docente, seis professores $(7,89 \%$ da amostra) referiram atuar também em outras atividades remuneradas com ou sem vínculo empregatício, são elas: administração de escola própria dirigida a cursos de dança, artes e técnicas corporais; montagem e comércio de semi-jóias; trabalho como revisor e tradutor; artesanato; cargo de supervisora escolar na prefeitura e vínculo no município como coordenadora pedagógica.

A análise da situação funcional em relação ao número de cargos mostrou que estavam na ativa $52,63 \%$ dos professores que assumiam dois cargos e que somente $5,26 \%$ dos professores que assumiam apenas um cargo estavam readaptados (Tabela 12).

A readaptação funcional de um professor significa, grosso modo, seu afastamento das atividades em sala de aula. A readaptação ocorre como resultante de um processo de avaliação da capacidade laborativa do funcionário, a qual é realizada pelo Departamento de Saúde do Servidor da Prefeitura Municipal de São Paulo (DESS), 
órgão municipal especializado para esse tipo de perícia. Entre outras atribuições, o DESS também é responsável pela validação das licenças médicas solicitadas pelos servidores municipais.

Tabela 12 - Relação entre número de cargos e situação funcional dos participantes.

\begin{tabular}{lrrrrrr}
\hline Número de cargos & \multicolumn{2}{c}{$\begin{array}{l}\text { Um } \\
\mathrm{n} \mathrm{( \% )}\end{array}$} & \multicolumn{2}{c}{$\begin{array}{c}\text { Dois } \\
\mathrm{n}(\%)\end{array}$} & \multicolumn{1}{c}{$\begin{array}{c}\text { Total } \\
\mathrm{n}(\%)\end{array}$} \\
\hline Ativo & 29 & 76,32 & 20 & 52,63 & 49 & 64,47 \\
Licença Médica & 6 & 15,79 & 8 & 21,05 & 14 & 18,42 \\
Readaptado & 2 & 5,26 & 9 & 23,68 & 11 & 14,47 \\
Acidente de trabalho & 1 & 2,63 & 1 & 2,63 & 2 & 2,63 \\
\hline Total & 38 & 100,00 & 38 & 100,00 & 76 & 100,00 \\
\hline
\end{tabular}

$p=0,059$

Após o processo de readaptação o professor passa a desenvolver atividades administrativas na escola, de acordo com o laudo pericial de sua condição laborativa. As readaptações são inicialmente provisórias podendo ser renovadas anualmente ou tornadas definitivas.

Em nossa amostra, encontramos que 54,55\% dos readaptados estavam entre 45 dias e um ano e meio nessa condição, enquanto os demais estavam entre 3 a 8 anos em readaptação. Outro aspecto observado foi que $72,73 \%$ dos participantes readaptados ingressaram na carreira docente entre 1983 e 1997 e que, portanto, atuavam na educação entre 31 a 17 anos.

\subsection{Aspectos motivacionals}

Entre os participantes, $65,79 \%$ sentiam-se realizados como professores; $15,79 \%$ afirmaram não se sentir realizados; $14,47 \%$ referiram que "às vezes" se sentiam realizados e 3,95\% não souberam ou não responderam. 
Quando perguntado sobre o interesse em atuar em outra ocupação, 55,26\% da amostra afirmou que não gostaria de trabalhar em outra atividade; 43,42\% referiu que gostaria de atuar em outra ocupação e 1,32\% não soube ou não respondeu à questão.

Entre os que se sentiam realizados como professores, 38\% afirmaram interesse em atuar em outra ocupação.

Os participantes que afirmaram ter interesse por outra ocupação (43,42\% da amostra) referiram funções, profissões ou tipos de atividade os quais foram agrupados em cinco áreas de interesse (Tabela 13). Uma das categorias de interesse não se referiu a nenhuma profissão ou função específica, mas ao desejo de que o trabalho, nas palavras dos participantes, "não envolva contato com pessoas ou com alunos".

Tabela 13 - Distribuição dos participantes que tinham interesse em outra ocupação segundo áreas.

\begin{tabular}{lrr}
\hline Área de Interesse & $\mathrm{n}$ & $\%$ \\
\hline Administração / Banco/ Diretoria de Escola & 10 & 30,30 \\
Outra ocupação relacionada à Educação & 9 & 27,28 \\
Assistência Social / Ocupação em Área de Saúde & 6 & 18,18 \\
Artes / Decoração / Eventos & 4 & 12,12 \\
Ocupação sem contato com pessoas ou alunos & 4 & 12,12 \\
\hline Total & 33 & 100,00 \\
\hline
\end{tabular}

\subsection{ASPECTOS RELACIONADOS AO AMBIENTE Físico dA ESCOLA E DAS SALAS DE} AULA

Avaliamos a opinião dos participantes quanto a aspectos do ambiente de trabalho nas escolas (iluminação, limpeza, poeira, adequação dos materiais e também de acústica das salas de aula). Esse levantamento está resumido na Tabela 14. 
$\mathrm{Na}$ amostra estudada, encontramos associação entre o sentimento de realização do professor e as variáveis: acústica da sala de aula $(p=0,012)$; poeira $(p=0,027)$ e limpeza $(p=0,029)$.

Tabela 14 - Avaliação dos participantes sobre o ambiente físico da escola e salas de aula.

\begin{tabular}{|c|c|c|c|c|c|c|c|c|}
\hline \multirow{2}{*}{$\begin{array}{l}\text { Aspecto do ambiente } \\
\text { escolar } \\
\text { Iluminação da sala }\end{array}$} & \multicolumn{2}{|c|}{$\begin{array}{c}\text { Aceitável } \\
\text { n (\%) }\end{array}$} & \multicolumn{2}{|c|}{$\begin{array}{c}\text { Não Aceitável } \\
\text { n (\%) }\end{array}$} & \multicolumn{2}{|c|}{$\begin{array}{l}\text { NS /NR * } \\
\text { n (\%) }\end{array}$} & \multicolumn{2}{|r|}{$\begin{array}{l}\text { Total } \\
\text { n (\%) }\end{array}$} \\
\hline & 61 & $(80,26)$ & 15 & $(19,74)$ & - & - & 76 & $(100,00)$ \\
\hline Limpeza da sala & 58 & $(76,32)$ & 17 & $(22,37)$ & 1 & $(1,32)$ & 76 & $(100,00)$ \\
\hline Poeira na sala & 51 & $(67,11)$ & 25 & $(32,89)$ & - & - & 76 & $(100,00)$ \\
\hline Adequação Materiais & 33 & $(43,42)$ & 43 & $(56,58)$ & - & - & 76 & $(100,00)$ \\
\hline Acústica da sala & 32 & $(42,11)$ & 44 & $(57,89)$ & - & - & 76 & $(100,00)$ \\
\hline
\end{tabular}

* NS/NR: não sabe / não responde

Entre os participantes, $65,79 \%$ afirmaram que há falta de recursos materiais necessários para o trabalho, o que mostrou ter relação com a percentagem de 56,58\% (Tabela 14) que consideraram "não aceitável” a adequação dos recursos materiais disponíveis para o trabalho $(p<0,001)$.

Entre os materiais não disponíveis foi relatada pelos participantes a falta de: materiais didáticos, artigos de papelaria, equipamentos de tecnologia dirigidos ao ensino e falta de material lúdico. Os professores da pesquisa também apontaram a falta de adequação das áreas externas da escola (quadras e parques).

A Tabela 15 apresenta outros resultados da investigação sobre aspectos relacionados ao ambiente físico e contexto geral das escolas.

Ressaltamos que apenas $11,84 \%$ dos participantes afirmaram que o barulho dentro da sala de aula "não incomoda" e que uma pequena parte dos investigados $(13,16 \%)$ referiu não sentir incômodo com o ruído da escola. O sentimento de realização 
profissional apresentou relação com o ruído da sala $(p=0,048)$.

Tabela 15 - Avaliação dos professores sobre aspectos do ambiente escolar.

\begin{tabular}{|c|c|c|c|c|c|}
\hline $\begin{array}{l}\text { Aspectos do } \\
\text { ambiente escolar }\end{array}$ & $\begin{array}{l}\text { Sim } \\
\mathrm{n}(\%)\end{array}$ & $\begin{array}{l}\text { Não } \\
\text { n (\%) }\end{array}$ & $\begin{array}{c}\text { Às vezes } \\
n(\%)\end{array}$ & $\begin{array}{l}\text { NS/NR * } \\
\mathrm{n}(\%)\end{array}$ & $\begin{array}{l}\text { Total } \\
\mathrm{n}(\%)\end{array}$ \\
\hline $\begin{array}{l}\text { Incômodo com } \\
\text { ruído da sala }\end{array}$ & $\begin{array}{l}48 \\
(63,16)\end{array}$ & $\begin{array}{c}9 \\
(11,84)\end{array}$ & $\begin{array}{l}19 \\
(25,00)\end{array}$ & $\begin{array}{l}- \\
-\end{array}$ & $\begin{array}{c}76 \\
(100,00)\end{array}$ \\
\hline $\begin{array}{l}\text { Incômodo com } \\
\text { ruído da escola }\end{array}$ & $\begin{array}{l}46 \\
(60,53)\end{array}$ & $\begin{array}{l}10 \\
(13,16)\end{array}$ & $\begin{array}{c}19 \\
(25,00)\end{array}$ & $\begin{array}{l}1 \\
(1,32)\end{array}$ & $\begin{array}{c}76 \\
(100,00)\end{array}$ \\
\hline $\begin{array}{l}\text { Existe local de } \\
\text { descanso }\end{array}$ & $\begin{array}{l}16 \\
(21,05)\end{array}$ & $\begin{array}{l}60 \\
(78,95)\end{array}$ & - & - & $\begin{array}{c}76 \\
(100,00)\end{array}$ \\
\hline $\begin{array}{l}\text { Existe favela } \\
\text { próx. à escola }\end{array}$ & $\begin{array}{l}68 \\
(89,47)\end{array}$ & $\begin{array}{c}8 \\
(10,53)\end{array}$ & $\begin{array}{l}- \\
-\end{array}$ & $\begin{array}{l}- \\
-\end{array}$ & $\begin{array}{c}76 \\
(100,00)\end{array}$ \\
\hline $\begin{array}{l}\text { Problema na } \\
\text { escola }\end{array}$ & $\begin{array}{l}63 \\
(82,89)\end{array}$ & $\begin{array}{l}12 \\
(15,79)\end{array}$ & - & $\begin{array}{l}1 \\
(1,32)\end{array}$ & $\begin{array}{c}76 \\
(100,00)\end{array}$ \\
\hline
\end{tabular}

* NS/NR: não sabe / não responde

Na percepção de $82,89 \%$ dos entrevistados, existiam problemas na escola que os incomodavam ou que precisariam ser sanados. Os problemas referidos foram agrupados em sete categorias, apresentadas na Tabela 16.

Tabela 16 - Categorias de problemas identificados nas escolas pelos participantes.

\begin{tabular}{lcc}
\hline Tipo de Problema & $\mathrm{n}$ & $\%$ \\
\hline Infraestrutura: espaço físico, recursos humanos, jornada & 26 & 27,37 \\
Problemas de gestão, direção & 18 & 18,95 \\
Contato com alunos, comportamento dos alunos & 12 & 12,63 \\
Salas superlotadas & 11 & 11,58 \\
Relativos aos pais dos alunos e à comunidade & 10 & 10,53 \\
Problemas nas relações entre colegas professores & 9 & 9,47 \\
Barulho & 9 & 9,47 \\
\hline Total & 95 & 100,00 \\
\hline
\end{tabular}

Observamos que $67,37 \%$ dos problemas apontados pelos professores no estudo se 
referiram a questões de ordem administrativa ou de organização do contexto educacional (infraestrutura, gestão, superlotação das salas e barulho).

Por outro lado, 32,23\% dos problemas relatados pelos professores se referiram a questões do contato interpessoal no trabalho, ou seja, dificuldades sentidas ao contato com os alunos, com os pais, com a comunidade e também dificuldades no contato entre os professores.

\subsection{Aspectos Relacionados ao contato com os alunos, pais e colegas}

$\mathrm{Na}$ amostra estudada, a quantidade de alunos atendidos diariamente variou entre 0 (zero) e 420 alunos/dia. À parte a situação de quatro professores readaptados que referiram não atender alunos, a variação no número de estudantes atendidos pelos professores está relacionada às graduações do processo educacional.

O número de alunos por turma aumenta em correspondência à idade dos alunos. Assim, as primeiras salas da educação infantil (berçários e minigrupos) têm em média 9 alunos para cada professora. No ensino fundamental I as salas são formadas por 30 a 35 alunos e os professores podem atender de uma a três turmas diariamente. No nível de ensino fundamental II e no nível médio, cada sala de aula tem de 35 a 40 alunos e os professores desses níveis dão aulas a várias turmas diariamente.

Observamos, por meio da Tabela 17, que estavam na ativa $71,74 \%$ dos indivíduos que referiram atender até 69 alunos diariamente. Por outro lado, entre os professores que referiram atender de 70 a 420 alunos diariamente, 43,33\% estavam em licença médica no momento da pesquisa.

Entre os participantes, $15,79 \%$ referiram que o contato com os alunos incomodava; $39,47 \%$ referiram que esse contato não incomodava e $44,74 \%$ referiram que "às vezes" o contato com os alunos incomodava.

Observamos associação entre o sentimento de incômodo com os alunos e não se 
sentir realizado profissionalmente $(p=0,023)$.

Tabela 17 - Relação entre o número de alunos atendidos e a situação funcional dos pesquisados.

\begin{tabular}{lrrrc}
\hline Número diário de alunos & \multicolumn{2}{c}{0 a 69} & \multicolumn{2}{c}{$\begin{array}{c}70 \text { a } 420 \\
\mathrm{n}(\%)\end{array}$} \\
\hline Ativo & 33 & $(71,74)$ & 16 & $(53,33)$ \\
Licença Médica & 1 & $(2,17)$ & 13 & $(43,33)$ \\
Readaptados & 11 & $(23,91)$ & - & - \\
Acidente de trabalho & 1 & $(2,17)$ & 1 & $(3,33)$ \\
\hline Total & 46 & $(100,00)$ & 30 & $(100,00)$ \\
\hline
\end{tabular}

$p<0,001$

No grupo de professores que se incomodava no contato com o aluno, ou que se incomodava às vezes $(60,53 \%)$, foram levantadas a origem ou as justificativas para esse incômodo, as quais foram agrupadas em cinco categorias (Tabela 18).

Tabela 18 - Identificação da causa do incômodo no contato com os alunos.

\begin{tabular}{lrr}
\hline Tipo de problema & $\mathrm{n}$ & $\%$ \\
\hline Agressividade, indisciplina & 19 & 27,53 \\
Déficits dos alunos: físicos, emocionais, sociais & 16 & 23,19 \\
Barulho, agitação & 15 & 21,74 \\
Sentimento de falha pessoal, insegurança & 14 & 20,29 \\
Excesso de alunos & 5 & 7,25 \\
\hline Total & 69 & 100,00
\end{tabular}

Nota-se que o sentimento de falha pessoal ou insegurança representou 20,29\% das causas do incômodo, não muito aquém da mais referida causa de incômodo: agressividade e indisciplina por parte dos alunos $(27,53 \%)$.

Quase havia unanimidade $(94,74 \%)$ entre os participantes de que existia elevado número de alunos por classe. 
A análise mostrou associação entre atender até 70 alunos diariamente e o sentimento de realização profissional $(p=0,004)$.

Além disso, 88,16\% dos professores em nossa amostra afirmaram observar mau comportamento (que ultrapassa o esperado para a idade da criança) por parte dos alunos (Tabela 19).

Tabela 19 - Frequência de mau comportamento dos alunos.

\begin{tabular}{lcr}
\hline Observação de mau comportamento & $\mathrm{n}$ & $\%$ \\
\hline Diariamente & 52 & 77,61 \\
Às vezes & 14 & 20,90 \\
Semanalmente & 1 & 1,49 \\
\hline Total & 67 & 100,00 \\
\hline
\end{tabular}

Na Tabela 20 encontram-se os dados da avaliação dos professores em relação à necessidade de atualização profissional, aspectos burocráticos e também acerca do contato com os pais dos alunos.

Observamos associação entre o sentimento de realização profissional e não sentir incômodo no contato com os pais dos alunos $(p=0,005)$.

Tabela 20 - Avaliação de aspectos burocráticos e do contato com os pais dos alunos.

\begin{tabular}{llllc}
\hline & \multicolumn{1}{c}{$\begin{array}{c}\text { Nim } \\
\mathrm{n}(\%)\end{array}$} & $\begin{array}{c}\text { Não } \\
\mathrm{n}(\%)\end{array}$ & $\begin{array}{c}\text { Às vezes } \\
\mathrm{n}(\%)\end{array}$ & $\begin{array}{c}\text { Total } \\
\mathrm{n}(\%)\end{array}$ \\
\hline $\begin{array}{lllll}\text { Sente necessidade de } \\
\text { atualização profissional }\end{array}$ & 64 & 12 & - & 76 \\
Sente-se sobrecarregado & $54,21)$ & $(15,79)$ & - & $(100,00)$ \\
de atividades & $(71,05)$ & $(22,37)$ & $(6,58)$ & $(100,00)$ \\
Atividades burocráticas & 48 & 26 & 2 & 76 \\
são excessivas & $(63,16)$ & $(34,21)$ & $(2,63)$ & $(100,00)$ \\
Contatos com os pais & 46 & 23 & 7 & 76 \\
são programados & $(60,53)$ & $(30,26)$ & $(9,21)$ & $(100.00)$ \\
Contato com os pais dos & 10 & 34 & 32 & 76 \\
alunos incomoda & $(13,16)$ & $(44,74)$ & $(42,11)$ & $(100,00)$ \\
\hline
\end{tabular}


A soma dos participantes que referiram sentir incômodo no contato com os pais dos alunos com aqueles que referiram ter esse sentimento "às vezes", correspondeu a $55,27 \%$ da amostra.

Agrupamos em sete categorias as principais causas referidas ao incômodo no contato com os pais e as apresentamos na Tabela 21.

Tabela 21 - Causas de incômodo no contato com os pais dos alunos.

\begin{tabular}{lrr}
\hline Causa & $\mathrm{n}$ & $\%$ \\
\hline Negligência, ausência, despreparo dos pais & 21 & 34,42 \\
Agressividade dos pais: dirigida ao professor ou aos filhos & 15 & 24,59 \\
Transferência indevida de responsabilidade ao professor & 8 & 13,11 \\
Superproteção dos pais aos filhos & 6 & 9,84 \\
Professor sente-se despreparado no contato com os pais & 5 & 8,20 \\
Cobrança excessiva dos pais aos filhos & 3 & 4,92 \\
Omissão ou intrusão da coord. pedagógica & 3 & 4,92 \\
\hline Total & 61 & 100,00 \\
\hline
\end{tabular}

Na Tabela 22, apresentamos o modo como os participantes observam outras instâncias escolares. Ressaltamos que apenas 26,32\% dos participantes referiu que não sente falta de apoio por parte da coordenação da escola.

Tabela 22 - Aspectos relacionados à coordenação, aos colegas e à instituição escolar.

\begin{tabular}{llllc}
\hline & $\begin{array}{c}\text { Sim } \\
\mathrm{n}(\%)\end{array}$ & \multicolumn{1}{c}{ Não } & Às vezes & Total \\
& $\mathrm{n}(\%)$ & $\mathrm{n}(\%)$ & $\mathrm{n}(\%)$ \\
\hline Sente falta de apoio da & 29 & 20 & 27 & 76 \\
coordenação da escola & $(38,16)$ & $(26,32)$ & $(35,53)$ & $(100,00)$ \\
Sente falta de apoio dos & 23 & 27 & 26 & 76 \\
colegas & $(30,26)$ & $(35,53)$ & $(34,21)$ & $(100,00)$ \\
Sente que participa das & 20 & 19 & 37 & 76 \\
decisões institucionais & $(26,32)$ & $(25,00)$ & $(48,68)$ & $(100,00)$ \\
\hline
\end{tabular}




\subsection{ASPECTOS RELACIONADOS À SAÚDE E LICENÇAS MÉDICAS}

Entre os entrevistados, 46,05\% haviam iniciado atendimento psicoterápico. Todos os professores em psicoterapia estavam entre a primeira e a oitava sessão de atendimento. Profissionais com maior tempo em psicoterapia não foram incluídos para que a amostra fosse o mais homogênea possível quanto ao critério de ter indicação de psicoterapia, ou seja, não ter iniciado o tratamento psicoterápico ou estar no início do mesmo (considerado até a oitava sessão).

$\mathrm{Na}$ avaliação da própria saúde feita pelos participantes ressalta que apenas 3,95\% deles consideraram sua saúde ótima (Tabela 23).

Tabela 23 - Avaliação da própria saúde do ponto de
\begin{tabular}{lrr} 
participantes. \\
\cline { 2 - 3 } Saúde & $\mathrm{n}$ & $\%$ \\
\hline Ótima & 3 & 3,95 \\
Boa & 15 & 19,74 \\
Regular & 31 & 40,79 \\
Frágil & 21 & 27,63 \\
Ruim & 6 & 7,89 \\
\hline Total & 76 & 100,00 \\
\hline
\end{tabular}

A análise mostrou que a variável avaliação da própria saúde apresentou associação com o uso regular de medicamentos $(p=0,040)$.

Observamos que 76,32\% dos participantes referiram estar em uso regular de medicamentos. Entre estes professores foi levantado: o nome do medicamento e o motivo pelo qual está sendo utilizado. Observamos a partir desse inquérito que algumas vezes um medicamento estava sendo utilizado devido a seus efeitos colaterais, como no caso do uso de anti-hemético (Dramin ou Dimenidrinato) como ansiolítico e indutor de sono. Em outros casos foi referido o uso de antipsicótico (Sulpirida) como antidepressivo e também o uso de antipsicótico atípico (Quetiapina) 
como estabilizador de humor. Estes medicamentos foram então incluídos nas categorias medicamentosas de acordo com a finalidade para a qual estavam sendo utilizados e não em suas categorias de base.

Todos os medicamentos em uso regular referidos pelos participantes foram agrupados de acordo com categorias medicamentosas (Tabela 24).

Tabela 24 - Distribuição dos remédios em uso regular pelos participantes, conforme categorias medicamentosas. *

\begin{tabular}{lrr}
\hline Categorias Medicamentosas & $\mathrm{n}$ & $\%$ \\
\hline Antidepressivos (inclusive Sulpirida) & 31 & 19,50 \\
Anti-hipertensivos / Diuréticos & 28 & 17,61 \\
Antidislipidémico / Hipocolesterolemiante & 16 & 10,06 \\
Medicamentos citados até 3 vezes ** & 16 & 10,06 \\
Ansiolíticos / Anti-hemético (como indutor de sono) & 11 & 6,92 \\
Anti-ulcerosos & 11 & 6,92 \\
Antidiabético & 10 & 6,29 \\
Hormônios da tiróide & 10 & 6,29 \\
Anticonvulsivantes / Estabilizadores de humor*** & 7 & 4,40 \\
Anti-inflamatórios / Analgésicos & 6 & 3,77 \\
Fitoterápicos / Antroposóficos / Homeopáticos & 5 & 3,14 \\
Anti-alérgicos & 4 & 2,52 \\
Corticóides & 4 & 2,52 \\
\hline Total & 159 & 100,00 \\
\hline
\end{tabular}

* Obs.: A relação completa de medicamentos citados está disponível no Anexo 5.

** Foram incluídos nessa categoria medicamentos que não se enquadram nas categorias propostas e que foram citados até três vezes: 9 medicamentos citados apenas uma vez (antivaricoso; antirreumático, entre outros); 2 medicamentos citados duas vezes (cálcio e anticoncepcional); e vitamina, citada três vezes.

*** Inclusive Quetiapina.

Observamos que a categoria medicamentosa mais prevalente foi a de antidepressivos $(19,50 \%)$, e que a soma de referências ao uso de remédios relacionados a problemas mentais (Antidepressivos, Ansiolíticos, Anticonvulsivantes e Estabilizadores de humor) correspondeu a 30,82\% do total de referências. 
Outro aspecto observado foi que a soma das referências ao uso de remédios relacionados à síndrome metabólica (Anti-hipertensivos, Diuréticos, Antidislipidémicos ou Hipocolesterolemiantes e Antidiabéticos) correspondeu a $33,96 \%$ do total de referências.

Duas professoras referiram espontaneamente o uso de anticoncepcional oral. Por não se tratar de questão relacionada à disfunção ou problema de saúde, o presente estudo não investigou entre todas as participantes o uso desse tipo de medicamento. Assim, os anticoncepcionais foram categorizados juntamente com outros tipos de medicamentos "menos citados".

Entre os participantes $81,58 \%$ afirmaram ter problemas de saúde. Os tipos de problemas de saúde e ou motivo pelo qual são usados os medicamentos citados foram agrupados em doze categorias e são apresentados na Tabela 25.

Tabela 25 - Problemas de saúde referidos pelos participantes, em categorias.

\begin{tabular}{lrr}
\hline Tipo de Problema de Saúde & $\mathrm{n}$ & $\%$ \\
\hline Psiquiátricos / Insônia & 33 & 21,15 \\
Relacionados à Síndrome Metabólica / Obesidade & 32 & 20,51 \\
Ortopédicos / Musculares / Reumatológicos & 17 & 10,90 \\
Problemas Gástricos / Proctológicos & 14 & 8,97 \\
Alérgicos / Rinite / Asma & 11 & 7,05 \\
Endocrinológicos & 9 & 5,77 \\
Psicológicos / Esgotamento & 8 & 5,13 \\
Fonoaudiológicos & 8 & 5,13 \\
Vasculares / AVCs / Cardíacos & 7 & 4,49 \\
Dermatológicos / Ginecológicos / Gestação & 6 & 3,85 \\
Enxaqueca / ATM/ Glaucoma/ Pólipo Nasal & 6 & 3,85 \\
Parkinson / HIV / Lúpus/ CA mama / Hepatite medic. & 5 & 3,20 \\
\hline Total & 156 & 100,00 \\
\hline
\end{tabular}

${ }^{*}$ Condições de saúde citadas apenas uma vez.

A respeito de tratamentos de saúde, atuais ou já encerrados, $86,84 \%$ dos participantes 
responderam afirmativamente. Constatamos que os tratamentos citados se relacionaram aos problemas de saúde referidos na Tabela 25.

$97,37 \%$ dos pesquisados responderam já ter se ausentado por motivo de saúde. $\mathrm{Na}$ Tabela 26 apresentamos a distribuição dos participantes de acordo com o número de vezes que se afastaram por licença médica (incluindo licença gestante).

Tabela 26 - Quantidade de licenças médicas utilizadas pelos participantes.

\begin{tabular}{lcc}
\hline Número de vezes & $\mathrm{n}$ & $\%$ \\
\hline Entre 1 e 2 & 18 & 24,32 \\
Entre 2 e 4 & 20 & 27,03 \\
Entre 5 e 8 & 21 & 28,38 \\
Mais que 8 vezes & 15 & 20,27 \\
\hline Total & 74 & 100,00 \\
\hline
\end{tabular}

As variáveis "duração da licença médica" e "sentimento de realização profissional" mostraram-se associadas $(p=0,008)$, assim como "número de licenças" e "avaliação da própria saúde" $(p=0,014)$.

Notamos que o maior percentual $(28,38 \%)$ correspondeu aos pesquisados que se afastaram por licença médica entre 5 a 8 vezes; mas foi quase uniforme a distribuição percentual entre as quatro faixas de frequência propostas.

A Tabela 27 apresenta a distribuição conforme a duração da licença médica. Três participantes $(4,05 \%$ dos que se ausentaram por licença médica) referiram duração superior a um ano do período de licença mais longo.

A distribuição dos participantes de acordo com sua situação funcional no momento da pesquisa com o motivo pelo qual ocorreu sua última licença médica está apresentada na Tabela 28. 
Tabela 27 - Distribuição em faixas temporais da carreira e dos períodos de licença mais longos.

\begin{tabular}{lcccccc}
\hline Período de licença mais longo & $\begin{array}{c}\text { + de 25 anos } \\
\text { de carreira } \\
\mathrm{n}(\%)\end{array}$ & $\begin{array}{c}\text { Menos de 25 } \\
\text { anos carreira } \\
\mathrm{n}(\%)\end{array}$ & Total \\
\hline De 2 dias até 1 mês & 4 & $(16,00)$ & 15 & $(30,61)$ & 19 & $(25,68)$ \\
+ de 1 mês até 3 meses & 3 & $(12,00)$ & 11 & $(22,45)$ & 14 & $(18,92)$ \\
+ de 3 meses até 6 meses & 9 & $(36,00)$ & 12 & $(24,49)$ & 21 & $(28,38)$ \\
+ de 6 meses até 9 meses & 2 & $(8,00)$ & 8 & $(16,33)$ & 10 & $(13,51)$ \\
+ de 9 meses até 1 ano & 5 & $(20,00)$ & 2 & $(4,08)$ & 7 & $(9,46)$ \\
+ de 1 ano até 2 anos & - & - & 1 & $(2,04)$ & 1 & $(1,35)$ \\
+ de 2 anos até 3 anos & 1 & $(4,00)$ & - & - & 1 & $(1,35)$ \\
+ de 3 anos até 4 anos & 1 & $(4,00)$ & - & - & 1 & $(1,35)$ \\
\hline Total & 25 & $(100,00)$ & 49 & $(100,00)$ & 74 & $(100,00)$ \\
\hline
\end{tabular}

$p=0,060$

Em relação ao motivo da última licença médica, observamos que os problemas emocionais foram os mais prevalentes $(40,54 \%)$.

Tabela 28 - Distribuição dos participantes conforme sua situação funcional no momento da pesquisa e o motivo pelo qual solicitou sua última licença médica.

\begin{tabular}{|c|c|c|c|c|c|}
\hline $\begin{array}{l}\text { Problema de } \\
\text { saúde }\end{array}$ & $\begin{array}{l}\text { Ativo } \\
\mathrm{n}(\%)\end{array}$ & $\begin{array}{l}\text { CAT } \\
\mathrm{n}(\%)\end{array}$ & $\begin{array}{c}\text { Licença } \\
\text { Médica } \\
\text { n (\%) }\end{array}$ & $\begin{array}{l}\text { Readap. } \\
\text { n (\%) }\end{array}$ & $\begin{array}{l}\text { Total } \\
\text { n (\%) }\end{array}$ \\
\hline Dor muscular & $3(6,38)$ & $1(50,00)$ & - & $1(9,09)$ & $5(6,76)$ \\
\hline Gastrointestinais & $3(6,38)$ & - & - & $1(9,09)$ & $4(5,41)$ \\
\hline Outros & $\begin{array}{l}15 \\
(31,91)\end{array}$ & $\begin{array}{l}- \\
-\end{array}$ & $4(28,57)$ & $2(18,18)$ & $\begin{array}{l}21 \\
(28,38)\end{array}$ \\
\hline $\begin{array}{l}\text { Problemas } \\
\text { emocionais }\end{array}$ & $\begin{array}{c}16 \\
(34,04)\end{array}$ & $1(50,00)$ & $\begin{array}{l}10 \\
(71,43)\end{array}$ & $3(27,27)$ & $\begin{array}{l}30 \\
(40,54)\end{array}$ \\
\hline $\begin{array}{l}\text { Problemas } \\
\text { vocais }\end{array}$ & $\begin{array}{l}10 \\
(21,28)\end{array}$ & - & - & $4(36,36)$ & $\begin{array}{l}14 \\
(18,92)\end{array}$ \\
\hline Total & $\begin{array}{l}47 \\
(100,00)\end{array}$ & $\begin{array}{c}2 \\
(100,00)\end{array}$ & $\begin{array}{c}14 \\
(100,00)\end{array}$ & $\begin{array}{c}11 \\
(100,00)\end{array}$ & $\begin{array}{c}74 \\
(100,00)\end{array}$ \\
\hline
\end{tabular}

$p=0,104$ 
Os problemas emocionais também foram os mais prevalentes entre os professores que estavam em licença médica no momento da participação na pesquisa: 71,43\%. Por outro lado, entre os participantes readaptados os problemas vocais foram os mais prevalentes como motivo de sua última licença médica $(36,36 \%)$.

A Tabela 29 apresenta a relação entre o número de alunos atendidos diariamente e o motivo da última licença médica. Notamos que $52,78 \%$ dos participantes que atendiam mais de 50 alunos diariamente referiram problemas emocionais como motivo de sua última licença médica.

Entre os professores que atendiam até 50 alunos diariamente, a categoria "outros problemas de saúde" apresentou a maior proporção (34,21\%).

Tabela 29 - Relação entre o número de alunos atendidos diariamente e o motivo da última licença médica.

\begin{tabular}{lccc}
\hline Problema de saúde & $\begin{array}{c}\text { Profs. com até } \\
50 \text { alunos } \\
\mathrm{n}(\%)\end{array}$ & $\begin{array}{c}\text { Profs. com }+ \\
\text { de } 50 \text { alunos } \\
\mathrm{n}(\%)\end{array}$ & $\begin{array}{c}\text { Total } \\
\mathrm{n}(\%)\end{array}$ \\
\hline Dor muscular & $5(13,16)$ & - & $5(6,76)$ \\
Gastrointestinais & $2(5,26)$ & $2(5,56)$ & $4(5,41)$ \\
Outros & $13(34,21)$ & $8(22,22)$ & $21(28,38)$ \\
Problemas emocionais & $11(28,95)$ & $19(52,78)$ & $30(40,54)$ \\
Problemas vocais & $7(18,42)$ & $7(19,44)$ & $14(18,92)$ \\
\hline Total & $38(100,00)$ & $36(100,00)$ & $74(100,00)$ \\
\hline
\end{tabular}

$p=0,069$

A Tabela 30 apresenta a relação entre a quantidade de alunos atendidos diariamente e a avaliação do professor da relação entre o trabalho e seus problemas de saúde. Notamos que $68,42 \%$ dos participantes consideraram que seus problemas de saúde tinham relação com o trabalho docente.

Entre os profissionais que atendiam mais de 70 alunos diariamente $82,61 \%$ avaliaram que o trabalho estava relacionado com seus problemas de saúde; e nenhum dos 
participantes desse grupo considerou que o trabalho não tinha relação com seus problemas de saúde.

Tabela 30 - Avaliação da relação entre o trabalho e seus problemas de saúde e a quantidade de alunos atendidos diariamente pelo participante.

\begin{tabular}{lccc}
\hline $\begin{array}{l}\text { Existe relação } \\
\text { saúde } x \text { trabalho }\end{array}$ & $\begin{array}{c}\text { Profs. com até } \\
70 \text { alunos } \\
\mathrm{n}(\%)\end{array}$ & $\begin{array}{c}\text { Profs. com }+ \\
\text { de } 70 \text { alunos } \\
\mathrm{n}(\%)\end{array}$ & Total \\
\hline Sim & $33(62,26)$ & $19(82,61)$ & $52(68,42)$ \\
Não sabe / & $11(20,75)$ & $4(17,39)$ & $15(19,74)$ \\
Não respondeu & $9(16,98)$ & - & $9(11,84)$ \\
Não & $53(100,00)$ & $23(100,00)$ & $76(100,00)$ \\
\hline Total & & & \\
\hline
\end{tabular}

$p=0,076$

Aos participantes que referiram relação entre o trabalho e seus problemas de saúde (físicos ou emocionais), foi solicitado que relatassem como isso acontecia. Entre as respostas, observa-se que $48,05 \%$ deles atribuiu o desenvolvimento de sintomas às condições estressantes vivenciadas no contexto escolar (Tabela 31).

Tabela 31 - Modos pelos quais os participantes sentem o trabalho afetando sua saúde.

\begin{tabular}{|c|c|c|}
\hline Modos pelos quais o trabalho afeta a saúde & $\mathrm{n}$ & $\%$ \\
\hline $\begin{array}{l}\text { Atribui sintomas ao estresse vivido na escola / observa } \\
\text { melhora dos sintomas quando não trabalha }\end{array}$ & 37 & 48,05 \\
\hline $\begin{array}{l}\text { Falhas de infraestrutura / acústica deficiente / pouco intervalo } \\
\text { para descanso / excesso de alunos em classe }\end{array}$ & 11 & 14,29 \\
\hline Devido ao uso da voz: constante, excessivo ou inadequado & 9 & 11,69 \\
\hline $\begin{array}{l}\text { Devido ao contato com alunos: drogados, indisciplinados, } \\
\text { chorosos, portadores de deficiências ou problemáticos }\end{array}$ & 8 & 10,39 \\
\hline $\begin{array}{l}\text { Falta de apoio ou desrespeito: por parte da equipe, } \\
\text { coordenação ou por parte de colegas }\end{array}$ & 6 & 7,79 \\
\hline $\begin{array}{l}\text { Cobranças que não podem ser cumpridas / desmotivação } \\
\text { com a escola ou com a profissão }\end{array}$ & 6 & 7,79 \\
\hline Total & 77 & 100,00 \\
\hline
\end{tabular}


A avaliação dos participantes de que seus problemas de saúde tinham relação com o trabalho mostrou associação com as seguintes variáveis: agressão a outras pessoas ( $p$ $=0,005)$; duração do período de licença mais longo $(p=0,008)$ e ter sofrido agressão dentro da escola $(p=0,032)$.

\subsection{ASPECTOS RELACIONADOS À VIOLÊNCIA, OU AGRESSIVIDADE, DENTRO E FORA DA ESCOLA}

Nessa seção são apresentados os resultados da pesquisa relativos a agressões ou violência vivenciados dentro ou fora da escola. Uma parte da investigação levantou as situações em que o participante foi o alvo direto da agressão, outra parte pesquisou as situações em que a agressão foi dirigida a outras pessoas (colega, aluno, funcionário, etc.). Além disso, foi levantada a opinião do participante sobre a ocorrência de danos (físicos ou emocionais) em função da agressão sofrida.

\subsubsection{Situações de agressão fora da escola - dirigidas ao participante}

Entre os participantes, $15,79 \%$ referiram ter sofrido agressão ou violência ocorrida fora da escola nos últimos doze meses. As agressões referidas foram agrupadas em quatro tipos e são apresentados na Tabela 32. Entre elas, a trágica referência ao homicídio do filho de uma participante, morto, segundo ela, em uma ação do crime organizado dirigida a jovens inocentes.

Tabela 32 - Tipo de agressão ou violência sofrida fora da escola, pelo participante, no período de até doze meses antes da pesquisa.

\begin{tabular}{lcr}
\hline Tipo de agressão & $\mathrm{n}$ & $\%$ \\
\hline Assalto ou tentativa & 5 & 41,67 \\
Ofensa verbal & 4 & 33,33 \\
Questões em família & 2 & 16,67 \\
Homicídio de familiar & 1 & 8,33 \\
\hline Total & 12 & 100,00 \\
\hline
\end{tabular}


Entre os participantes que referiram agressão fora da escola, 91,67\% consideraram ter sofrido danos físicos ou emocionais em função da violência ocorrida.

A Tabela 33 apresenta a relação dos danos atribuídos à agressão sofrida fora da escola, no período de até doze meses antes da participação na pesquisa. As diversas queixas referidas pelos professores foram agrupadas em cinco categorias, notando-se a predominância dos danos emocionais.

Tabela 33 - Danos atribuídos à agressão sofrida fora da escola, pelo participante, no período de até doze meses antes da pesquisa.

\begin{tabular}{lcc}
\hline Tipo de dano & $\mathrm{n}$ & $\%$ \\
\hline Insegurança, medo & 8 & 44,44 \\
Sintomas físicos: dores, insônia & 3 & 16,67 \\
Tristeza, mágoa, apatia, baixa autoestima & 3 & 16,67 \\
Nervosismo, irritabilidade, ansiedade & 2 & 11,11 \\
Desequilíbrio, agressividade & 2 & 11,11 \\
\hline Total & 18 & 100,00 \\
\hline
\end{tabular}

\subsubsection{Agressão ou violência dentro da escola - dirigida ao participante}

Quanto a ter sofrido agressão ou violência dentro da escola nos últimos doze meses, $51,32 \%$ dos participantes responderam afirmativamente.

As ocorrências relatadas pelos professores foram agrupadas em seis categorias, apresentadas na Tabela 34. A soma das categorias "ofensa verbal por alunos ou pais" e "ameaças por parte de alunos ou pais" chegou a 52,94\% do total de referências a agressões sofridas pelos participantes. Destacamos que as agressões físicas provocadas por alunos ou funcionários representaram 17,65\% do total de agressões sofridas dentro da escola.

Entre os que referiram ter sido vítimas de agressão dentro da escola, 87,18\% 
avaliaram a ocorrência de danos físicos ou emocionais em função da violência sofrida. Agrupamos em seis categorias os sintomas relatados como decorrentes da violência sofrida dentro da escola e elas estão descritas na Tabela 35.

Tabela 34 - Agressões sofridas pelos participantes dentro da escola no período de até doze meses antes da pesquisa.

\begin{tabular}{lrr}
\hline Tipo de agressão dentro da escola & $\mathrm{n}$ & $\%$ \\
\hline Ofensa verbal por alunos ou pais & 22 & 43,14 \\
Assédio moral dos gestores ou colegas & 11 & 21,57 \\
Agressão física por alunos ou funcionários & 9 & 17,65 \\
Ameaças por parte de alunos ou pais & 5 & 9,80 \\
Alunos desafiadores, provocadores & 3 & 5,88 \\
Falha da direção levando a ofensa por pais & 1 & 1,96 \\
\hline Total & 51 & 100,00 \\
\hline
\end{tabular}

Observamos que a categoria referente aos sintomas físicos (dores no corpo, tensão, insônia e hematomas) foi uma das mais prevalentes, assim como a dos sintomas depressivos (tristeza, desânimo e sentimento de culpa), ambas as categorias com $24,07 \%$ do total de referências.

Tabela 35 - Danos relacionados pelos participantes à agressão sofrida dentro da escola.

\begin{tabular}{lcc}
\hline Danos decorrentes de agressão dentro da escola & $\mathrm{n}$ & $\%$ \\
\hline Sintomas físicos: tensão, dores no corpo, insônia, hematomas & 13 & 24,07 \\
Depressão, tristeza, desânimo, sentimento de culpa & 13 & 24,07 \\
Preocupação, ansiedade, desconfiança & 9 & 16,67 \\
Medo da escola, desmotivação para trabalhar na escola & 9 & 16,67 \\
Medo, insegurança, claustrofobia & 5 & 9,26 \\
Desequilíbrio emocional, ódio, ideação agressiva & 5 & 9,26 \\
\hline Total & 54 & 100,00 \\
\hline
\end{tabular}

Observamos na Tabela 36 que 82,05\% dos participantes que sofreram agressão na escola nos últimos doze meses avaliaram que o trabalho docente tinha relação com 
seus problemas de saúde. Por outro lado, entre os professores que não sofreram agressão na escola apenas $16,22 \%$ avaliaram que o trabalho docente não tinha relação com seus problemas de saúde.

Tabela 36 - Relação entre ter sido agredido na escola e a consideração de que o trabalho está relacionado aos seus problemas de saúde.

\begin{tabular}{|c|c|c|c|}
\hline & $\begin{array}{l}\text { Sofreu } \\
\text { agressão na } \\
\text { escola } \\
\mathrm{n}(\%)\end{array}$ & $\begin{array}{c}\text { Não sofreu } \\
\text { agressão } \\
\text { na escola } \\
\text { n (\%) }\end{array}$ & $\begin{array}{l}\text { Total } \\
\mathrm{n}(\%)\end{array}$ \\
\hline $\begin{array}{l}\text { Avalia que o trabalho tem } \\
\text { relação com seus problemas } \\
\text { de saúde }\end{array}$ & $\begin{array}{l}32 \\
(82,05)\end{array}$ & $\begin{array}{l}20 \\
(54,05)\end{array}$ & $\begin{array}{l}52 \\
(68,42)\end{array}$ \\
\hline Não sabe / não respondeu & $\begin{array}{c}4 \\
(10,26)\end{array}$ & $\begin{array}{c}11 \\
(29,73)\end{array}$ & $\begin{array}{l}15 \\
(19,74)\end{array}$ \\
\hline $\begin{array}{l}\text { Avalia que o trabalho não tem } \\
\text { relação com seus problemas } \\
\text { de saúde }\end{array}$ & $\begin{array}{l}3 \\
(7,69)\end{array}$ & $\begin{array}{c}6 \\
(16,22)\end{array}$ & $\begin{array}{c}9 \\
(11,84)\end{array}$ \\
\hline Total & $\begin{array}{c}39 \\
(100,00)\end{array}$ & $\begin{array}{c}37 \\
(100,00)\end{array}$ & $\begin{array}{c}76 \\
(100,00)\end{array}$ \\
\hline
\end{tabular}

$p=0,032$

\subsubsection{Agressão ou violência - dirigida a outras pessoas}

Quanto a agressões dirigidas a outras pessoas, 78,95\% dos participantes relataram conhecer pessoas que sofreram agressão ou violência no período de até doze meses antes da realização da pesquisa.

Os colegas (professores) foram os mais citados como alvo de agressões (63,33\%). A segunda categoria mais citada foi "colegas e alunos": $16,67 \%$. A soma dessas duas categorias correspondeu a $80,00 \%$ do total.

A Tabela 37 apresenta todas as referências dos participantes a pessoas que sofreram agressões ou violência no período considerado. Observamos que apenas 8,33\% dessas referências não incluem professores como alvo de agressão. 
Tabela 37 - Outras pessoas que sofreram agressão no período de até doze meses antes da pesquisa, conforme relatado pelos participantes.

\begin{tabular}{lcc}
\hline Pessoas que sofreram agressão ou violência & $\mathrm{n}$ & $\%$ \\
\hline Colega $^{*}$ & 38 & 63,33 \\
Colega e aluno & 10 & 16,67 \\
Parente & 2 & 3,33 \\
Aluno & 2 & 3,33 \\
Parente e colega & 2 & 3,33 \\
Colega e outros & 2 & 3,33 \\
Parente, amigo, colega e aluno & 2 & 3,33 \\
Outros & 1 & 1,67 \\
Amigo e colega & 1 & 1,67 \\
\hline Total & 60 & 100,00 \\
\hline
\end{tabular}

* Nessa tabela a palavra colega se refere a outro professor.

As agressões a outras pessoas relatadas pelos participantes foram agrupadas em oito categorias e estão descritas na Tabela 38. As duas categorias mais prevalentes foram a agressão física e a ofensa verbal, ambas provocadas por alunos ou pais. Juntos, esses dois tipos de agressão somaram 64,36\%. Também foram relatados casos de violência grave a outras pessoas em situações externas à escola: estupro de aluna, violência doméstica e homicídios.

Tabela 38 - Tipos de agressão a outras pessoas ocorridas no período de até doze meses antes da pesquisa.

\begin{tabular}{lccc}
\hline Tipo de agressão sofrida por outras pessoas & $\mathrm{n}$ & $\%$ \\
\hline Agressão física por alunos ou pais & 29 & 33,33 \\
Ofensa verbal por alunos ou pais & 27 & 31,03 \\
Assédio moral ou omissão por gestores ou colegas & 7 & 8,04 \\
Ameaças ou acusações por alunos ou pais & 6 & 6,90 \\
Assaltos, sequestros relâmpago, danos pessoais ou materiais & 6 & 6,90 \\
Desrespeito ou preconceito por parte dos alunos & 4 & 4,60 \\
Agressões físicas, verbais, estupro entre alunos & 4 & 4,60 \\
Violência doméstica, homicídio & 4 & 4,60 \\
\hline Total & 87 & 100,00 \\
\hline
\end{tabular}


Entre os participantes que relataram agressão a outras pessoas, 93,33\% avaliaram que as agressões referidas desencadearam danos físicos ou emocionais às pessoas que as sofreram.

Agrupamos em dez categorias os tipos de danos a outras pessoas considerados pelos participantes (Tabela 39). A categoria mais prevalente é a relativa a sintomas emocionais: medo, insegurança e claustrofobia $(21,25 \%)$.

Destacamos que $18,75 \%$ dos danos citados são referentes a situações em que o alvo da agressão (professor ou funcionário da escola) precisou de licença médica, entrou com notificação de acidente de trabalho (CAT) ou iniciou processo de readaptação funcional em virtude da violência sofrida na escola.

Tabela 39 - Danos físicos e emocionais referidos pelos participantes como consequência de agressões sofridas por outras pessoas

\begin{tabular}{lrr}
\hline Tipo de dano outra pessoa & $\mathrm{n}$ & $\%$ \\
\hline Medo, insegurança, claustrofobia & 17 & 21,25 \\
Afastamento, licença, CAT, readaptação & 15 & 18,75 \\
Desequilíbrio emocional, abalo psicológico, estresse & 10 & 12,50 \\
Tristeza, depressão, desânimo, culpa & 9 & 11,25 \\
Desmotivação para trabalhar na escola, medo da escola & 8 & 10,00 \\
Danos materiais ou físicos & 6 & 7,50 \\
Alunos e ou pais afetados pela violência na escola & 5 & 6,25 \\
Sentimento de desamparo legal, processo judicial & 4 & 5,00 \\
Sintomas físicos: tensão, dor no corpo, insônia, hematomas & 3 & 3,75 \\
Preocupação, desconfiança, ansiedade & 3 & 3,75 \\
\hline Total & 80 & 100,00 \\
\hline
\end{tabular}

\subsection{Resultados das aVAliações de desGaste PROFISSIONAL}

Para a análise quantitativa dos inventários MBI e CESQT, esses instrumentos de investigação psicológica foram inicialmente apurados segundo suas instruções 
específicas. Em seguida, foi ponderada a intensidade de burnout aferida por meio desses inventários e realizada uma análise entre os resultados apresentados pelos participantes em cada um dos testes.

Posteriormente, investigamos a associação entre os resultados da escala Exaustão Emocional do MBI e da escala Desgaste Psíquico do CESQT, como também a associação de cada uma dessas escalas com as variáveis levantadas por meio do questionário sócio demográfico.

\subsubsection{Apuração do MBI}

Os resultados do MBI foram calculados em cada uma das três escalas para cada indivíduo, de acordo com as normas indicadas por Maslach et al. (1996, 2010). Os autores estabeleceram os níveis baixo, médio ou alto em cada escala e conceituaram que os resultados mais altos e em maior número de escalas correspondem a níveis mais altos da síndrome de burnout. (Anexo 6: Apuração de resultados individuais no MBI)

A Tabela 40 apresenta os resultados obtidos pelos participantes nas três escalas do MBI. Observamos que na escala Exaustão Emocional, 67,11\% dos professores pontuou nível alto de burnout. Por outro lado, a escala Despersonalização foi a que apresentou a menor proporção de indivíduos com alto escore de burnout: 11,84\%.

Tabela 40. Resultados obtidos pelos participantes em cada escala do MBI.

\begin{tabular}{lcccc}
\hline Nível de burnout & Alto & Médio & Baixo & Total \\
& $\mathrm{n}(\%)$ & $\mathrm{n}(\%)$ & $\mathrm{n}(\%)$ & $\mathrm{n}(\%)$ \\
\hline \multirow{2}{*}{ Exaustão Emocional } & 51 & 12 & 13 & 76 \\
& $(67,11)$ & $(15,79)$ & $(17,11)$ & $(100,00)$ \\
Despersonalização & 9 & 15 & 52 & 76 \\
& $(11,84)$ & $(19,74)$ & $(68,42)$ & $(100,00)$ \\
Envolvimento Pessoal & 35 & 15 & 26 & 76 \\
& $(46,05)$ & $(19,74)$ & $(34,21)$ & $(100,00)$ \\
\hline
\end{tabular}

A partir dos resultados no MBI, realizamos uma distribuição dos participantes de 
acordo com a intensidade e o número de escalas em que atingiram burnout no inventário. Para isso foram estabelecidos nove níveis de intensidade: desde os indivíduos que não atingiram burnout em nenhuma escala até os participantes que o atingiram nas três escalas do teste.

Não se propõe uma hierarquia entre as escalas, apenas uma ponderação cumulativa entre elas.

Os níveis referentes à intensidade e quantidade de escalas de burnout atingidas no MBI e o número de pessoas correspondentes estão descritos na Tabela 41.

Tabela 41. Distribuição dos participantes de acordo com a intensidade e quantidade de escalas em que atingiram burnout no $\mathrm{MBI}$.

\begin{tabular}{lrr}
\hline Intensidade e quantidade de escalas & $\mathrm{n}$ & $\%$ \\
\hline Não atingiu nenhuma escala & 8 & 10,53 \\
Médio em 1 escala & 8 & 10,53 \\
Médio em 2 escalas & 2 & 2,63 \\
Alto em 1 escala & 12 & 15,79 \\
Alto em 1 escala e médio em 1 & 11 & 14,47 \\
Alto em 1 escala e médio em 2 & 5 & 6,58 \\
Alto em 2 escalas & 14 & 18,42 \\
Alto em 2 escalas e médio em 1 & 9 & 11,84 \\
Alto em 3 escalas & 7 & 9,21 \\
\hline Total & 76 & 100,00 \\
\hline
\end{tabular}

Para melhor visualização dessa distribuição, convertemos esses dados em um gráfico de barras (Figura 2). Observamos que nos três primeiros níveis encontram-se 23,69\% dos indivíduos; nos três níveis intermediários a proporção é de $36,84 \%$; e nos três últimos níveis, correspondentes à maior intensidade de burnout, encontramos $39,47 \%$ da amostra. 
Figura 2. Gráfico da distribuição dos participantes de acordo com a intensidade de burnout aferida por meio do MBI.

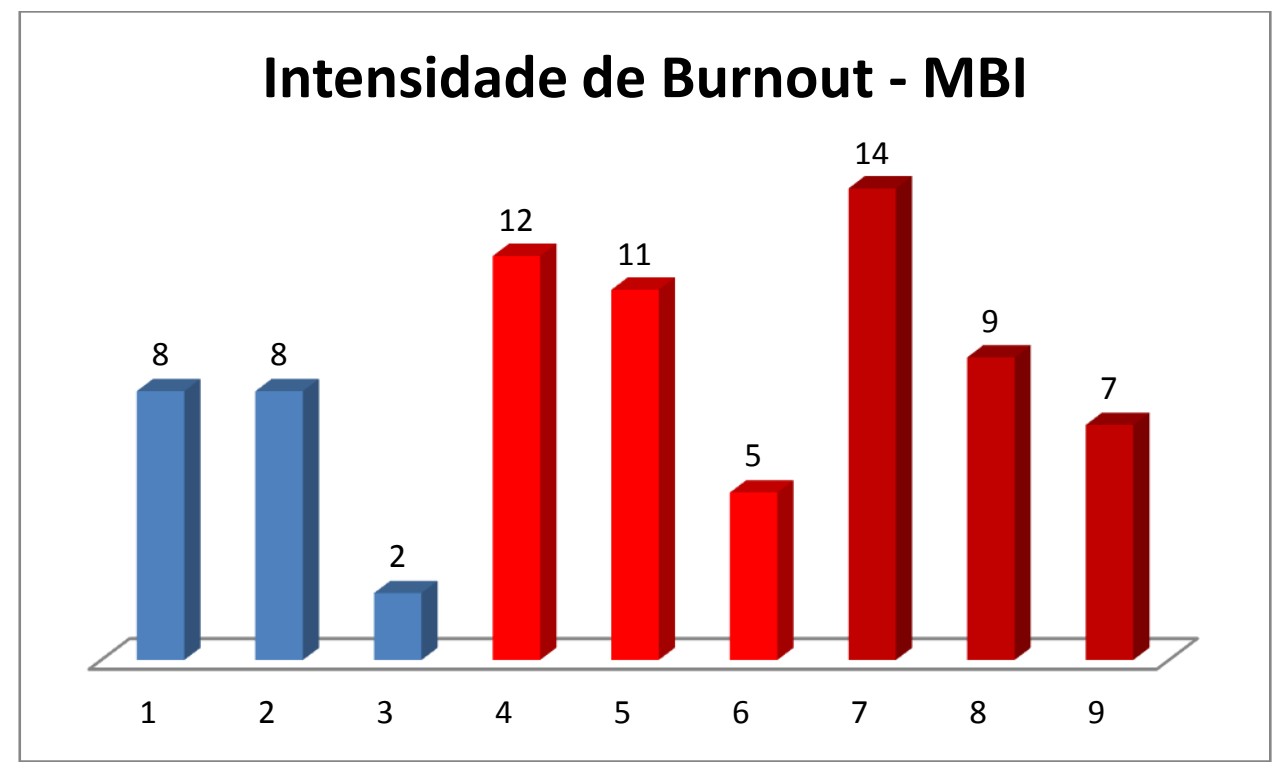

\subsubsection{Apuração do CESQT}

O inventário CESQT também foi apurado para cada participante conforme as instruções indicadas por Gil-Monte et al. (2010). Nesse inventário cada escala é considerada a partir de um único ponto de corte, a partir do qual é considerada a presença ou ausência de burnout em relação ao aspecto avaliado pela escala.

Assim como o MBI, o CESQT possui uma característica cumulativa, isto é, considera que quanto maior o número de escalas em que é atingido o nível de burnout por um indivíduo, mais intensa é a síndrome no mesmo. (Anexo 7: Apuração de resultados individuais no CESQT.)

A Tabela 42 apresenta a apuração dos resultados dos professores distribuídos de acordo com as quatro escalas do CESQT. Destacamos que na escala Desgaste Psíquico 81,58\% dos investigados apresentou burnout "positivo". 
Tabela 42. Resultados obtidos pelos participantes nas escalas do CESQT.

\begin{tabular}{lccc}
\hline Presença de burnout & Sim & Não & Total \\
& $\mathrm{n}(\%)$ & $\mathrm{n}(\%)$ & $\mathrm{n}(\%)$ \\
\hline \multirow{2}{*}{ llusão pelo Trabalho } & 19 & 57 & 76 \\
& $(25,00)$ & $(75,00)$ & $(100,00)$ \\
Desgaste Psíquico & 62 & 14 & 76 \\
& $(81,58)$ & $(18,42)$ & $(100,00)$ \\
Indolência & 14 & 62 & 76 \\
& $(18,42)$ & $(81,58)$ & $(100,00)$ \\
Culpa & 28 & 48 & 76 \\
& $(36,84)$ & $(63,16)$ & $(100,00)$ \\
\hline
\end{tabular}

Ponderamos a distribuição dos resultados no CESQT de acordo com o número de escalas em que os participantes atingiram burnout neste teste. Consideramos os resultados da escala de Culpa como agravante que pode estar acompanhado ou não de ter sido atingido nível de burnout nas demais escalas. Foram estabelecidos oito níveis de intensidade: desde os indivíduos que não atingiram burnout em nenhuma escala até os participantes que o atingiram nas quatro escalas desse inventário. Novamente, não se propõe uma hierarquia entre as escalas, apenas uma ponderação cumulativa entre elas. Os níveis referentes à de quantidade de escalas de burnout atingidas no CESQT e o número de pessoas correspondentes estão na Tabela 43.

Tabela 43. Distribuição dos participantes conforme intensidade de burnout no CESQT.

\begin{tabular}{lrr}
\hline Escalas de burnout atingidas & $\mathrm{n}$ & \multicolumn{1}{c}{$\%$} \\
\hline Nenhuma escala & 8 & 10,53 \\
Somente escala de culpa & 3 & 3,95 \\
Somente uma escala & 29 & 38,16 \\
Uma escala e escala de culpa & 15 & 19,74 \\
Duas escalas & 8 & 10,53 \\
Duas escalas e escala de culpa & 4 & 5,26 \\
Três escalas & 3 & 3,96 \\
Três escalas e escala de culpa & 6 & 7,89 \\
\hline Total & 76 & 100,00 \\
\hline
\end{tabular}


A visualização dos resultados da distribuição conforme intensidade de burnout no CESQT está disponível por meio da Figura 3.

Observamos que o terceiro nível de intensidade é o mais prevalente, o que está relacionado à grande proporção de indivíduos (81,58\%) diagnosticados como portadores de burnout por meio da escala Desgaste Psíquico desse inventário.

Por outro lado, a proporção de indivíduos que atingiu os dois níveis mais altos de intensidade de burnout no CESQT (isto é, burnout em 3 ou 4 escalas) correspondeu a $11,85 \%$.

Figura 3. Distribuição dos participantes conforme a quantidade de escalas de burnout atingidas no CESQT.

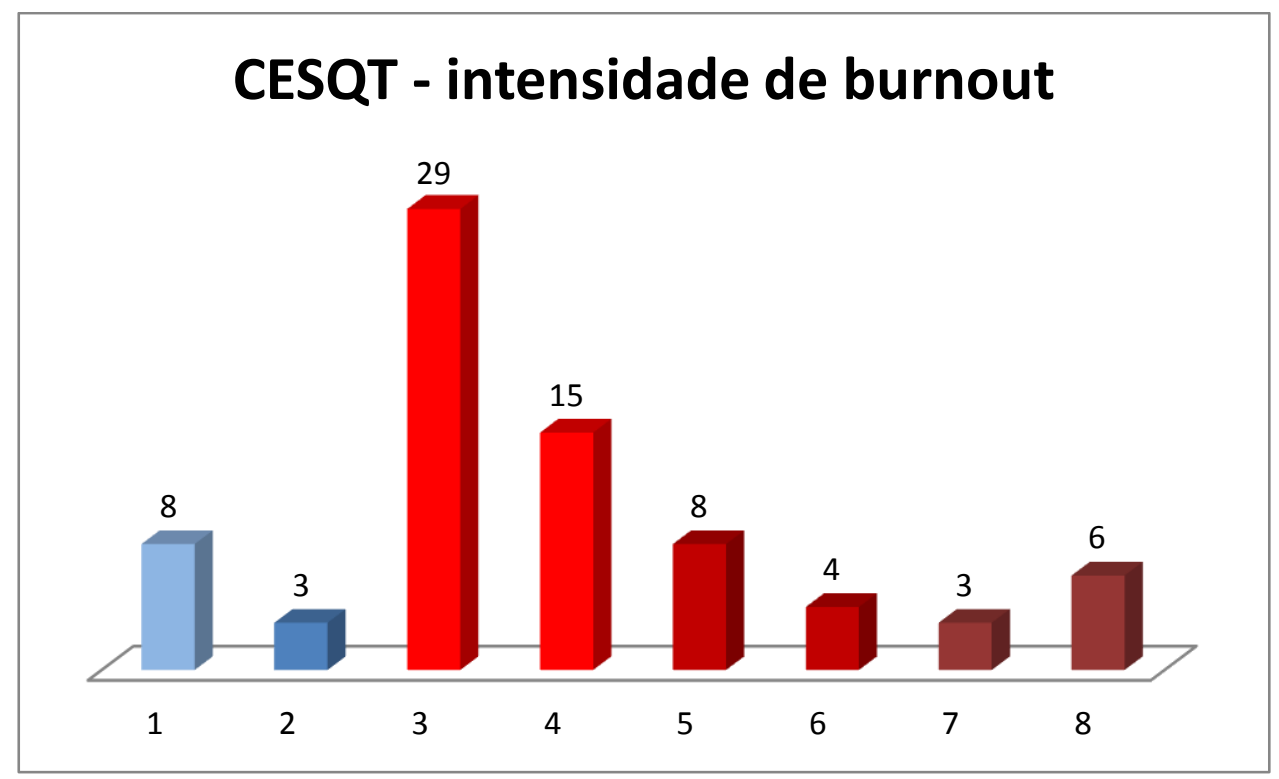

\subsubsection{Comparação entre MBI e CESQT}

Após a apuração dos resultados individuais, foram comparados entre si os resultados obtidos entre escalas Exaustão Emocional (EE) do MBI e Desgaste Psíquico (DP) do CESQT. Também foram analisadas as relações entre cada uma dessas escalas e as variáveis do questionário sócio demográfico. 
A Tabela 44 apresenta a relação entre os resultados da escala EE e da escala DP. Observamos que entre os $81,58 \%$ de participantes que pontuaram burnout (positivo) na escala DP, 98,04\% apresentaram burnout alto na escala EE. Além disso, na amostra estudada, apenas um indivíduo pontuou burnout alto na escala EE e negativo na escala DP.

Tabela 44. Relação entre os resultados dos participantes na escala Exaustão Emocional do MBI e na escala Desgaste Psíquico do CESQT.

\begin{tabular}{lcccc}
\hline CESQT & $\begin{array}{c}\text { Exaustão } \\
\text { Emocional } \\
\text { Alto } \\
\mathrm{n}(\%)\end{array}$ & $\begin{array}{c}\text { Exaustão } \\
\text { Emocional } \\
\text { Médio } \\
\mathrm{n}(\%)\end{array}$ & $\begin{array}{c}\text { Exaustão } \\
\text { Emocional } \\
\text { Baixo } \\
\mathrm{n}(\%)\end{array}$ & $\mathrm{n}(\%)$ \\
\hline $\begin{array}{l}\text { Desgaste } \\
\begin{array}{l}\text { Psíquico } \\
\text { Positivo }\end{array}\end{array}$ & $50(98,04)$ & $9(75,00)$ & $3(23,08)$ & $62(81,58)$ \\
$\begin{array}{l}\text { Desgaste } \\
\begin{array}{l}\text { Psíquico } \\
\text { Negativo }\end{array}\end{array}$ & $1(1,96)$ & $3(25,00)$ & $10(76,92)$ & $14(18,42)$ \\
\hline Total & $51(100,00)$ & $12(100,00)$ & $13(100,00)$ & $76(100,00)$ \\
\hline$p<0,001$ & & & &
\end{tabular}

$\mathrm{Na}$ análise das escalas dos inventários em relação aos dados levantados pelo questionário sociodemográfico foram observadas: 19 associações com a escala Exaustão Emocional do MBI e 11 associações com a escala Desgaste Psíquico do CESQT. As associações encontradas estão descritas a seguir.

Escala Exaustão Emocional - MBI e:

1. ruído da sala de aula $(p<0,001)$;

2. ruído da escola $(p<0,001)$;

3. ter sido agredido na escola $(p=0,001)$;

4. avaliação de que o trabalho tem relação com seus problemas de saúde ( $p=$ 0,002);

5. avaliação da própria saúde $(p=0,002)$;

6. incômodo no contato com os pais $(p=0,004)$; 
7. participação nas decisões da escola $(p=0,004)$;

8. apoio dos colegas $(p=0,008)$;

9. acústica da sala de aula $(p=0,009)$;

10. excesso de tarefas burocráticas $(p=0,029)$;

11. tempo como professor no município $(p=0,024)$;

12. tempo na carreira docente $(p=0,032)$;

13. nível de limpeza na sala $(p=0,037)$;

14. já ter mais de 25 anos como professor $(p=0,043)$;

15. contato com os pais são programados $(p=0,046)$;

16. existência de local para descanso na escola $(p=0,046)$;

17. atender até 70 alunos diariamente $(p=0,050)$;

18. situação funcional ( $p=0,059)$;

19. apoio da coordenação da escola $(p=0,062)$.

Escala Desgaste Psíquico - CESQT e:

1. ter sido agredido na escola $(p=0,003)$

2. avaliação da própria saúde $(p=0,005)$;

3. apoio da coordenação da escola $(p=0,005)$;

4. ruído da sala de aula $(p=0,006)$;

5. ruído da escola $(p=0,019)$;

6. participação nas decisões na escola $(p=0,019)$;

7. contato com os pais são programados $(p=0,026)$;

8. nível de limpeza na sala $(p=0,036)$;

9. tempo na carreira docente $(p=0,051)$;

10. excesso de tarefas burocráticas $(p=0,057)$;

11. situação funcional $(p=0,062)$;

Observamos que todas as variáveis que apresentaram associação com o CESQT, também apresentaram associação com o MBI. 


\section{DISCUSSÃO}

Embora baseado em uma amostra de demanda, este levantamento dos servidores em busca de tratamento psicoterápico nos pareceu uma forma de acesso válida ao contexto de saúde e de trabalho em que transitam os professores do município. Considerando que as queixas dos professores se referem em grande parte ao âmbito escolar, utilizamos o conceito de burnout na busca por dados objetivos que nos permitissem avaliar se e como o trabalho docente poderia se relacionar aos sintomas físicos e emocionais apresentados pelos professores.

O burnout se refere às relações entre o trabalho e a saúde dos profissionais que atuam provendo assistência a pessoas em situação de necessidade. O conceito de burnout propõe uma aproximação entre os sintomas físicos e emocionais expressados pelo trabalhador e o contexto ocupacional a que está submetido. Analisar como a organização do trabalho pode conduzir aos sintomas associados ao burnout evita que os problemas apresentados pelos profissionais sejam entendidos apenas de maneira individualizada, ou melhor, desvinculando o indivíduo do contexto de trabalho em que está inserido ou ainda desconsiderando o papel desse contexto na geração ou estímulo ao desenvolvimento dos sintomas expressados pelos trabalhadores.

Como discutido por MENDES e DIAS (1991): “o objeto da saúde do trabalhador pode ser definido como o processo saúde e doença dos grupos humanos, em sua relação com o trabalho. Representa um esforço de compreensão desse processo como e porque ocorre - e do desenvolvimento de alternativas de intervenção que levem à transformação em direção à apropriação pelos trabalhadores da dimensão humana do trabalho, numa perspectiva teleológica" (p. 347).

Além de meramente diagnosticar os profissionais (e abrir margem à medicalização de mais este agravo) avaliamos a necessidade de identificar aspectos do trabalho docente que possam estar associados à formação de sintomas de desgaste profissional no grupo de trabalhadores. $\mathrm{O}$ trabalho docente, e seus aspectos organizacionais, nos 
parecem o verdadeiro objeto a ser atingido; isto é, tentamos verificar se à expressão de sintomas apresentados pelos professores, além dos fatores de ordem individual, estão se somando fatores resultantes de processos organizacionais do contexto escolar.

Um elemento a ser considerado é a importante mudança ocorrida no contexto educacional brasileiro, conhecida como "democratização do ensino", processo que alterou profundamente o modelo pedagógico vigente (CARVALHO, 2004). A democratização teve o mérito de enfatizar a necessidade de oferecer educação universal e de evitar a marginalização escolar de grande parte das crianças ${ }^{7}$. Paulatinamente foram banidas as práticas punitivas e excludentes, onde até então se ancorava a autoridade (ou autoritarismo) do sistema educacional e foi lançado aos educadores o desafio de tornar o aprendizado uma experiência interessante para o aluno. Nesse processo, em que a educação e o aluno foram priorizados, o professor parece ter sido tomado como mais capacitado do que de fato estaria. Ou melhor, a democratização foi bem vinda, porém parece ter sido implantada a partir de regulamentações e regimentos, deixando a cargo dos professores a real mudança de práticas, porém sem o necessário investimento e adequação organizacional das escolas.

CODO (2002) em levantamento nacional de burnout entre professores referiu tanto agressões de alunos a professores quanto vice-versa. De fato, constatamos que muitos docentes foram educados num contexto em que o professor, em nome da educação, podia punir fisicamente um aluno. Entre esses profissionais, muitos julgam terem perdido a autoridade conjuntamente à palmatória - junção que nos parece imprópria.

Por outro lado, professores educados em modelos menos coercitivos, se queixam de que no atual sistema pedagógico os alunos (e seus pais) agem como se tivessem

\footnotetext{
7 De acordo com Azanha, citado por CARVALHO (2004), a Secretaria de Educação estimava que até 1968 menos de $20 \%$ das crianças em idade escolar chegavam à primeira série do curso ginasial no estado de São Paulo (p. 327).
} 
todos os direitos, mas nenhum dever a cumprir, uma vez que o sistema de avaliações e retenções ao final de cada ano foi abandonado. Nesse contexto o professor ressente-se e queixa-se de não ter poder que o faça ser respeitado, ou que permita uma disciplina em aula. Muitos professores afirmam não serem favoráveis à progressão continuada, a qual apesar de atacada por diversos setores da sociedade mantém-se e, além de evitar os altos níveis de evasão escolar vigentes até o seu advento, está fundamentada em concepção teórica e metodológica reconhecida em diversos países (PERRENOUD, 1999). Ressaltamos ainda que a progressão continuada está inserida em modelo pedagógico em que é preconizada a aprendizagem em ciclos.

Sucintamente, diríamos que a educação está passando por um processo de mudança paradigmática. Porém, devido à falta de investimento e gerenciamento organizacional que permita oferecer ensino universal e com qualidade, a categoria docente, que tem papel fundamental nesse processo, isoladamente não conseguirá alcançar as metas de quantidade e qualidade esperadas, além de recair sobre ela a forte pressão relacionada às expectativas dos gabinetes escolares como da sociedade.

É sabido que em processos de mudança os envolvidos vivem tensões, cobranças e temores relacionados a sentimentos contraditórios: deixar de lado concepções e práticas que se tornaram obsoletas, mas que permitiam previsibilidade e certa segurança. Nas palavras de muitos docentes encontramos o entendimento de que as novas práticas e concepções são inovadoras, porém não foram suficientemente implementadas. Por sua vez, a sociedade talvez só reconheça os benefícios da mudança pedagógica quando identificar claramente seus resultados positivos, por enquanto resta a crítica ao sistema atual e, principalmente, aos professores, os quais, de uma forma ou de outra, são os portadores da nova proposta educacional junto à população.

Avaliamos que a questão da mudança de paradigma na educação se soma às pressões sofridas pela categoria docente e pode contribuir para que o professor, como os demais envolvidos nesse contexto de trabalho, desenvolvam sintomas associados ao 
burnout.

Este trabalho se baseou em uma amostra composta em serviço de saúde e que, ainda que entre os participantes seja possível estabelecer relações entre as variáveis pesquisadas, não podemos generalizar diretamente as associações encontradas para a população total de professores que atuam no município. Entretanto, esperamos que os elementos aqui discutidos sejam úteis ao debate sobre aspectos de saúde dos professores e de suas condições de trabalho.

\subsection{Características sócio demográficas}

A predominância do sexo feminino na amostra $(92,11 \%)$ parece refletir a hegemonia feminina na atividade docente. Além disso, o estudo se dirigiu a professores com indicação para psicoterapia e a maciça participação feminina na pesquisa também pode estar relacionada à reconhecida maior atenção da mulher à própria saúde mental.

Consideramos que a proporção de $25 \%$ dos professores investigados residindo em cidades da grande São Paulo parece relacionada à proximidade dessas cidades às periferias da capital, pois parte significativa das escolas e creches do município de São Paulo está localizada nas regiões afastadas das áreas centrais. Da mesma forma, a maior concentração de equipamentos educativos municipais fora das áreas centrais da cidade também explicaria o pequeno número de participantes residentes na região Central da cidade de São Paulo (1,32\%).

A escolaridade se dividiu, no conjunto de participantes, entre graduados e pósgraduados; apenas $2,63 \%$ não havia concluído curso superior até o momento da pesquisa. Notamos que nem sempre foi requisitado o nível superior aos professores municipais, pois o curso técnico normal habilitava ao exercício da profissão.

Outro ângulo relacionado à escolarização dos professores é que, até 2002, as creches 
municipais eram ligadas à Secretaria do Bem Estar Social e os profissionais que educavam as crianças, os Auxiliares de Desenvolvimento Infantil (ADIs), não eram considerados professores. Isso significa que não havia requisito nem de curso superior nem de curso técnico normal para o exercício dessa função. Com a reestruturação administrativa iniciada em 2002, as creches passaram a ser equipamentos geridos pela Secretaria de Educação do município.

Essa passagem se deu por meio da lei no 13574 de 12 de maio de $2003^{8}$ que dispõe sobre a transformação e inclusão no quadro do magistério municipal do quadro dos profissionais de educação dos cargos de auxiliar de desenvolvimento infantil, pedagogo e diretor de equipamento social. A partir dessa transformação a prefeitura municipal ofereceu cursos superiores de capacitação e os ADIs tornaram-se, formalmente, professores. Aos professores "normalistas" também foi oferecida a graduação em curso superior de pedagogia. Entretanto, apesar da recompensa salarial, nem todos os servidores aderiram e concluíram a formação oferecida9 9

A variável escolaridade apresentou associação estatística com a avaliação de burnout realizada por CARVALHO (1995), que utilizou o MBI em amostra de 465 professores da rede pública de municípios da Delegacia de Ensino de Mogi Mirim - SP. Nesse trabalho, as variáveis "nível em que leciona" e "classes muito numerosas", entre outras, também apresentaram significância em relação aos níveis de burnout apurados por meio do MBI.

A presente amostra foi composta predominantemente por pessoas maduras, uma vez que apenas $22,37 \%$ dos participantes estavam na faixa de 29 a 39 anos de idade.

A carreira docente, por ser entendida como desgastante, prevê o direito à

\footnotetext{
${ }^{8}$ Disponível em:

http://www3.prefeitura.sp.gov.br/cadlem/secretarias/negocios juridicos/cadlem/integra.asp?a $\underline{\mathrm{t}=13052003 \mathrm{~L} \% 20135740000 \% 20 \% 20 \% 20 \% 20 \% 20 \% 20 \% 20 \% 20 \% 20 \% 20 \% 20 \% 20 \& \mathrm{secr}=}$ \&depto=\&descr_tipo=LEI Acessado em 18.07.2014.

${ }^{9}$ Observamos erros de grafia como: "ancia de vomito", "pescosso", etc.
} 
aposentadoria especial, ou seja, 25 anos de atuação na função permite acesso à aposentadoria por tempo de serviço. Entretanto, com as mudanças nas regras para aposentadoria e com a exigência da idade mínima (50 anos para docente mulher e 55 para homem), muitos professores sentem-se compelidos a manter-se na função além dos 25 anos de trabalho para acessar o benefício da aposentadoria integral. Aparentemente este é um, entre outros fatores, que levou a encontrar na ativa $60 \%$ dos profissionais que já ultrapassaram os 25 de carreira docente (Tabela 7).

Em nossa amostra, o estado civil foi um aspecto identificado em associação ao prolongamento do tempo de serviço na educação. Constatamos que $44 \%$ dos profissionais com mais de 25 anos de trabalho estavam separados ou divorciados, levando a considerar que a necessidade de manter-se trabalhando poderia estar relacionada à manutenção do orçamento familiar que, nesses casos, estaria mais referido ao participante. Por outro lado, seriam necessários mais elementos para afastar a possibilidade de que o maior número de separados e divorciados com mais de 25 anos de trabalho não seja devido apenas à necessidade de arcar com responsabilidades, mas também ao desejo e motivação de professores, talvez menos solicitados pela família, em manterem-se vinculados à profissão por mais tempo.

No município de São Paulo os professores podem manter mais de um cargo docente. Em nossa amostra 50\% dos participantes assumiam dois cargos na educação. Em geral a opção por dois cargos é justificada pelos professores em função das necessidades do orçamento familiar. Lembremos que a renda média das famílias na presente amostra foi de $\mathrm{R} \$ 5.398,68$ e que apenas $25 \%$ dos participantes não tinham filhos no momento da pesquisa. Avaliamos que seriam necessários mais dados para uma análise aprofundada em relação aos vencimentos e carga de trabalho, os quais, de todo modo, nos pareceram desproporcionais às qualificações e produtividade requeridas aos profissionais.

O acúmulo de cargos aumenta o tempo de jornada semanal sendo que 57,89\% dos participantes que acumulavam cargos estavam cumprindo 70 horas semanais. O cumprimento de dois cargos também implica em, se necessário, trabalhar em mais de 
uma escola e ter pouco tempo para transporte e alimentação entre os locais de trabalho - aspectos apontados pelos participantes entre os problemas de organização e de infraestrutura escolar.

$\mathrm{Na}$ amostra estudada, 80,26\% dos participantes atuavam em apenas um nível educacional no momento da pesquisa. Esse dado parece sugerir uma espécie de "especialização" ou preferência dos professores em relação aos níveis educacionais. Lembramos que a porção de 19,74\% de professores que atuam em mais de um nível inclui dois tipos de situação: os professores que não escolhem sala fixa porque atuam como substitutos; e os profissionais que atuam em dois cargos e escolhem salas em níveis educacionais diferentes pela necessidade de adequar-se às vagas disponíveis e locais de trabalho. Isto significa que, por vezes, pode predominar a preferência em concentrar os dois cargos na mesma escola (ou em escolas próximas), mesmo que em níveis diferentes de atuação. Eventualmente podem ocorrer situações como a relatada por uma das participantes: ela afirmou ter tido que assumir escolas em pontos extremamente distantes na cidade (um cargo seria cumprido na região de São Miguel Paulista, na zona leste, e o outro em Campo Limpo, zona sul de São Paulo) o que tornava praticamente impossível a manutenção dos dois cargos. A professora relatou que só conseguiu solucionar a situação após recorrer à Secretaria de Educação. Apesar de eventual, esse exemplo ilustra o quanto pode ser tensa (e frustrante) a escolha de salas pelos professores, principalmente quando acumulam dois cargos.

A considerável proporção de participantes fora da ativa no momento da pesquisa parece vinculada ao fato de se tratar de uma amostra composta por usuários de serviço de saúde de nível terciário: o Hospital do Servidor Público Municipal (HSPM). O HSPM centraliza a assistência à saúde dirigida ao servidor do município de São Paulo, recebendo as demandas dos servidores, residentes na capital ou não, frequentemente em situações em que licenças médicas e readaptação funcional já se encontram em curso.

Em relação à situação funcional dos participantes, constatamos que estão readaptados $23,68 \%$ dos professores que assumem dois cargos. Além disso, observamos que 
$72,73 \%$ dos professores em readaptação funcional estão atuando na educação desde 17 a 31 anos. Esses dados relativos à intensidade diária do atendimento e do desgaste dos profissionais na atuação em longo prazo corroboram a literatura sobre burnout (MASLACH et al., 2001), a qual associa o desgaste profissional a essas variáveis.

A análise mostrou que na amostra estudada há associação entre o número de alunos atendidos diariamente e a situação funcional no momento da pesquisa. Isto é, a proporção de professores na ativa é maior entre aqueles com menor número diário de alunos (até 69), dado que está em consonância com a literatura a respeito de burnout (SCHAUFELI et al., $2009^{10}$ ).

\subsection{ASPECTOS MOTIVACIONAIS E DO CONTEXTO ESCOLAR}

Com relação aos aspectos motivacionais, foi encontrado que $12,12 \%$ do grupo de professores que tem interesse em outra ocupação não tinham em mente nenhuma profissão ou função específica. Referiram como principal interesse apenas o de que a atividade não envolvesse contato com pessoas ou com alunos. Essa manifestação nos parece diretamente relacionada à percepção desses participantes de sua atual dificuldade no contato interpessoal, contato que é fundamental ao processo educativo e que é também a principal fonte de desgaste associada ao burnout (MASLACH et al., 2001).

A falta de recursos materiais necessários, além do incômodo com o barulho na sala de aula e com o barulho na escola foram os aspectos mais criticados quanto ao ambiente físico do trabalho.

$\mathrm{Na}$ amostra estudada, o sentimento de realização profissional, apresentou associação

\footnotetext{
${ }^{10}$ Estes autores referem ao "burnout no século XXI" o crescente número de pessoas a serem assistidas, acompanhado do aumento dos requisitos a serem oferecidos em descompasso à insuficiência dos recursos humanos e ou materiais para atender a tais demandas (p. 208 e 209).
} 
com aspectos físicos e com aspectos do contato interpessoal no contexto de trabalho. Quanto aos aspectos físicos, observamos associação com: acústica da sala de aula, nível de poeira, nível de limpeza e incômodo com o ruído da sala. Segundo o relato de muitos professores o excessivo número de alunos em sala leva à maior dificuldade em controlar a turma, aumentando o ruído e forçando o professor a falar mais alto e com repetições constantes. Uma professora observou que a proposta pedagógica (baseada na construção de competências) é interessante e vem de outros países onde, no entanto, o número de alunos em sala é de 15 para dois profissionais, enquanto aqui são 35 alunos para apenas um professor.

Relacionadas ao contato interpessoal, as seguintes variáveis apresentaram associação com o sentimento de realização profissional: atender até 70 alunos diariamente, sentir incômodo no contato com os pais dos alunos e sentir incômodo no contato com os alunos. Esses resultados mostram que o sentimento de realização profissional está em conexão com os aspectos do contato interpessoal, intrínsecos ao trabalho docente, como ao número de alunos atendidos diariamente.

Em relação ao contato com os alunos, a mais referida causa de incômodo: agressividade e indisciplina da parte dos alunos $(27,53 \%)$ foi apenas um pouco maior que a referência ao sentimento de falha pessoal ou insegurança relatado em 20,29\% das causas desse incômodo. Esse último dado nos parece relacionado a sentimentos de culpa em relação ao trabalho; a culpa por sua vez, tem sido considerada um dos sintomas vinculados ao desgaste profissional, isto é, à síndrome de burnout (GILMONTE, 2005).

Em relação à razão do incômodo no contato com os pais, as respostas se referiram a: atitudes ou deficiências dos pais (como alcoolismo, por exemplo), críticas à coordenação da escola e também, em relação aos pais, aparece a referência dos participantes aos próprios sentimentos negativos e à percepção do professor quanto a seu despreparo para esse contato interpessoal. Aparentemente o sentimento de despreparo, relacionado tanto ao contato com os pais como aos alunos, se vincula a sentimentos de culpa relacionados ao trabalho por parte dos entrevistados. 
Entre as razões referidas ao incômodo no contato com os pais, observamos que os participantes retrataram a coordenação pedagógica e a direção da escola como omissas, inoperantes ou ainda aliadas aos pais no "ataque" aos professores. Além disso, os participantes apontaram uma postura por vezes intrusiva da parte dos gestores e coordenadores pedagógicos, bem como foi referida a falta de apoio por essas instâncias escolares.

Consideramos que o aparente distanciamento e falta de apoio mútuo entre professores, coordenadores pedagógicos e direção da escola poderia ser mais um aspecto do ambiente escolar vinculado ao burnout, uma vez que este último é considerado como afetando a todos os envolvidos na situação de trabalho (CODO, 2002).

\subsection{Aspectos de Saúde}

Considerando que a amostra foi composta por pessoas em tratamento em unidade hospitalar e que $46,05 \%$ delas têm mais de 50 anos de idade, é esperado que o uso de medicações e que a necessidade de tratamentos de saúde apresentem prevalência importante.

Aparentemente há uma confirmação da avaliação de 35,52\% dos participantes que consideraram a própria saúde frágil ou ruim, uma vez que a soma das referências ao uso de remédios relacionados apenas à síndrome metabólica (anti-hipertensivos, diuréticos, antidislipidémicos ou hipocolesterolemiantes e antidiabéticos) correspondeu a $33,96 \%$ do total de referências a medicamentos em uso regular.

Por outro lado, a soma de referências ao uso de remédios relacionados a problemas psíquicos (antidepressivos, ansiolíticos, anticonvulsivantes e estabilizadores de humor) correspondeu a 30,82\% do total de referências ao uso de medicamentos, dado que parece vinculado às características da amostra investigada, ou seja, professores com indicação de atendimento psicoterápico. 
Apesar das fragilidades, $2,63 \%$ da amostra referiu nunca ter se afastado do trabalho por licença médica até o momento da pesquisa.

Em relação ao período de licença mais longo, foi mais prevalente a duração de até 6 meses (28,38\%); seguida pela duração de até 1 mês $(25,68 \%)$ e de até 3 meses $(18,92 \%)$. Foram incluídas nesse item as licenças gestante que atualmente na Prefeitura do Município de São Paulo correspondem a seis meses. Consideramos que a amostra, apesar de utilizar serviço terciário de atenção à saúde, em sua maior parte, utilizou licenças médicas curtas ou de média duração.

Por outro lado, as licenças de duração superior a dois anos concentraram-se entre os participantes com mais de 25 anos de carreira docente, ou seja, as licenças mais longas foram utilizadas pelos servidores que estão em serviço há mais tempo; e observamos associação entre a duração da licença médica e o sentimento de realização profissional.

Em sua maior parte, o motivo da última licença médica utilizada pelos participantes foram os problemas emocionais, dado que se relaciona ao critério de seleção da amostra: indicação de tratamento psicoterápico. Notamos que o número de alunos atendidos diariamente pode se relacionar ao afastamento por licença médica devida a problemas emocionais $(p=0,069)$, hipótese que poderia ser melhor avaliada se pudéssemos atingir número maior de participantes. Observamos o relato de irritabilidade, medo e insegurança diante dos alunos por parte de vários profissionais. Uma docente relatou ter desenvolvido estresse pós-traumático após episódio em que os alunos puseram fogo na sala (literalmente), fecharam a porta e esconderam o trinco, em outro episódio, relatado pela mesma professora, os alunos soltaram uma bomba dentro da sala de aula. Soma-se aos temores dos profissionais o fato de se sentirem responsáveis pela segurança de seus alunos, e de terem de prestar contas caso ocorra algum acidente ou lesão. Uma participante passou por episódio de depressão com sintomas paranoides após o acidente de um aluno. Ele quebrou o braço no parque da escola e seus pais abriram boletim de ocorrência policial visando ressarcimento de danos. Todos os funcionários tiveram de prestar depoimentos e a 
escola passou por perícias em várias ocasiões - situações que foram vivenciadas com extrema tensão por parte da professora.

\subsection{VIOLÊNCIA E AGRESSIVIDADE NO COTIDIANO ESCOLAR}

Os participantes destacaram diversas situações relacionadas à violência e agressividade no contexto escolar em várias oportunidades ao longo da pesquisa. Em relação a esses aspectos os participantes referiram o surgimento de sintomas físicos e emocionais.

Uma situação trazida por um dos participantes em readaptação funcional ilustrou o quanto a violência, que tem permeado o contexto escolar, pode trazer prejuízo aos envolvidos na situação de trabalho. O participante relatou que teve um dedo da mão quebrado quando tentou separar uma briga entre alunos. Após a licença por acidente de trabalho (CAT) ele não pôde permanecer em seu cargo original (professor de educação física) tendo que aceitar a readaptação funcional, indicada pela perícia do Departamento de Saúde do Servidor (DESS).

$68,42 \%$ dos profissionais consideraram que existe relação entre seus problemas de saúde e o trabalho. Essa avaliação dos participantes apresentou associação com outras cinco variáveis, entre elas com as variáveis "conhecer pessoas que foram vítimas de agressão"; e "ter sido vítima de agressão dentro da escola". A associação entre essas variáveis parece mostrar que os professores relacionam seus problemas de saúde ao trabalho na medida em que têm contato com situações de violência, seja quando o próprio professor foi vítima ou quando tem contato com outros que foram vítimas.

O que se depreende dos relatos e das análises é que, para boa parte dos professores, a escola representa um ambiente onde cotidianamente a hostilidade toma sentido estrutural, pela frequência constante e naturalidade com que é expressa por pais, alunos, funcionários e também pelos professores. Uma das participantes chegou a 
verbalizar sua compreensão desse fato explicando que há uma contaminação onde todos se tornam agressores e agredidos. Avaliamos que se soma a esse mal estar o sentimento de despreparo do professor, percebido pelos próprios profissionais; e notamos o ressentimento nas falas dos docentes: "não estudaram para isso", além da desmotivação e também do surgimento de defesas psíquicas para lidar com tais adversidades, aspectos também associados à síndrome de burnout (MASLACH et al., 2001)

\subsection{ANÁLISE dAS AVALIAÇÕES DE DESGASTE PROFISSIONAL}

Os instrumentos de avaliação psicológica foram utilizados na tentativa de tornar objetiva a mensuração de burnout na amostra. Observamos que os resultados apresentados pelos participantes no MBI mostraram mais indivíduos com nível alto de burnout nas escalas Exaustão Emocional e Envolvimento Pessoal que na escala Despersonalização. Além disso, tomando as três escalas desse teste em conjunto, notamos que $76,31 \%$ da amostra apresentou nível alto de burnout, em pelo menos uma escala.

No inventário CESQT a escala Desgaste Psíquico apresentou a maior proporção de participantes com burnout (81,58\%), a escala Culpa apresentou 36,84\% de indivíduos com burnout e as demais escalas apresentaram proporções menores. Considerando as quatro escalas do teste em conjunto, apenas $14,48 \%$ da amostra não atingiu nível de burnout nesse inventário, o qual está validado no Brasil.

$\mathrm{Na}$ análise da relação entre os resultados dos participantes na escala Exaustão Emocional (EE) do MBI e na escala Desgaste Psíquico (DP) do CESQT, ressaltamos que $98,04 \%$ dos participantes avaliados com alto escore de burnout em EE, foram avaliados como portadores de burnout na escala DP. Em concordância com este dado, observamos que em 76,92\% dos professores que apresentaram nível baixo de burnout na escala EE foi avaliada ausência de burnout por meio da escala DP. Avaliamos, portanto, que estas escalas apresentam concordância em relação ao 
diagnóstico de burnout no grupo de participantes.

As escalas EE e DP também apresentaram associação com numerosas variáveis investigadas pelo questionário sócio demográfico, indicando que aspectos do contexto de trabalho estão relacionados ao burnout apurado por meio dos inventários MBI e CESQT. 


\section{CONCLUSÕES}

No estudo dessa amostra de serviço, levantamos informações que apontam a ocorrência de sintomas físicos e emocionais e a referência dos participantes a diversos aspectos do contexto escolar que podem ser associados à síndrome de burnout entre os professores.

Notamos a presença de sintomas físicos e emocionais na amostra:

- 76,32 \% dos participantes estavam em uso regular de medicamentos;

- 81,58\% afirmaram ter problemas de saúde;

- 76,31\% dos participantes avaliaram a própria saúde como regular, frágil ou ruim;

Dentre os medicamentos em uso regular, 33,96\% eram relacionados à síndrome metabólica e $30,82 \%$ se referiam ao tratamento de transtornos psiquiátricos.

Além disso, notamos que a falta de realização profissional nos professores estava relacionada a períodos mais longos das licenças médicas.

Entre os aspectos do contexto escolar que podem ser associados ao burnout os mais destacados pelos participantes foram: o número de alunos atendidos diariamente e aspectos físicos do ambiente escolar: nível de barulho (na sala e na escola) e limpeza insuficiente. Consideramos que esses aspectos estão relacionados a uma implantação precária da democratização pedagógica e da proposta de aprendizagem em ciclos. Segundo os próprios professores, a proposta de construção de competências nos alunos, em todos os níveis do ensino, requer atenção individualizada e pequeno número de alunos para cada profissional, situação que está longe da realidade atual nas escolas no município.

Os aspectos relativos à escolaridade dos professores nos parecem vinculados às dificuldades e sofrimentos trazidos por eles. Boa parte dos educadores, que hoje atuam segundo a proposta de construção de competências nos alunos, foi escolarizada quando crianças ou adolescentes segundo o padrão pedagógico anterior a essa proposta (o qual se fundamentava na retenção pelos alunos dos conteúdos a 
eles apresentados). Também vimos que, até recentemente, não era requisitado nem mesmo o curso técnico normal para os profissionais que trabalhavam em creches. Portanto, apesar da capacitação oferecida pelo município, parte significativa dos docentes pode não ter tido a escolarização suficiente ao exercício de suas funções, entre elas a de escolarizar, e seriam necessários mais investimentos e estímulos à educação continuada dos profissionais.

Os professores admitiram espontaneamente o seu sentimento de despreparo para lidar com os alunos e com os pais. Esse despreparo parece se vincular a sentimentos de culpa, aspectos reconhecidamente relacionados à síndrome de burnout.

Observamos a referência à de falta de apoio entre as instâncias escolares: em relação ao incômodo no contato com os pais, entre outros aspectos, a coordenação pedagógica e direção da escola foram apontadas pelos participantes como insatisfatórias, omissas e até mesmo identificadas como "antagonistas" aos professores. Aparentemente o sentido de equipe, ou de grupo de trabalho não faz parte do cotidiano de boa parte dos educadores. Além disso, depreende-se que o esgotamento relacionado ao burnout pode estar atingindo a todas as instâncias na escola.

As referências à violência e agressividade no contexto escolar apontam o quanto as crianças e seus pais trazem à escola um modelo de contato interpessoal embrutecido e marcado por extrema privação cultural e social. Tais carências talvez possam ser atribuídas às múltiplas gerações que sofreram exclusão escolar e social, sendo assim, na medida em que o ciclo de exclusão escolar foi rompido, poderíamos esperar por uma superação das atitudes agressivas na escola ao longo do processo de inclusão vigente. Nesse momento, entretanto, os aspectos de agressividade e violência dentro da escola representam mais um elemento a ser trabalhado pelos professores, sendo um trabalho cujo resultado não é imediato e que pode gerar frustração ao profissional. Desse modo a violência dentro da escola é mais um fator a contribuir ao burnout e notamos que está relacionada, entre outros aspectos, à avaliação dos professores de que seus problemas de saúde tem relação com o trabalho. 
Por meio dos testes psicológicos utilizados, tanto no MBI quanto no CESQT, foi encontrada uma grande proporção de burnout entre os participantes: há indicativos de que pelo menos $75 \%$ da amostra sofrem de burnout. Essa grande proporção não é, de todo, inesperada, uma vez que as avaliações foram realizadas por usuários de serviço de saúde portadores de problemas emocionais. O que nos parece digno de nota é que os problemas e sintomas avaliados pelos inventários também são relativos ao contexto de trabalho. Nesse sentido, consideramos que para lidar com os sintomas apresentados pelos profissionais seriam necessárias ações dirigidas aos aspectos organizacionais do contexto escolar, como por exemplo: diminuição do número de alunos por professor e estímulo ao apoio mútuo entre professores, coordenadores pedagógicos e diretores de escola. Ações desse tipo poderiam trazer ganhos aos profissionais e também aos demais envolvidos: alunos, pais, e coordenação das escolas. 


\section{REFERÊNCIAS}

Aguayo R, Vargas C, de la Fuente EI, Lozano LM. A meta-analytic reliability generalization study of the Maslach Burnout Inventory. Int J Clin Health Psychol. $2011 ; 11(2): 343-61$.

Araújo TM, Carvalho FM. Condições de trabalho docente e saúde na Bahia: estudos epidemiológicos. Educ Soc 2009; 30 (107); 427-49.

Belcastro PA, Gold RS. Teacher stress and burnout: implications for school health personnel. J Sch Health 1983; 53(7): 404-7.

Classificação Estatística Internacional de Doenças e Problemas Relacionados à Saúde - CID-10. Centro Colaborador da OMS para a Classificação de Doenças em Português - CBCD [acesso em 25 jul 2014]. Disponível em:

http://www.datasus.gov.br/cid10/V2008/cid10.htm

Carlotto MS, Câmara SG. Análise fatorial do Maslach burnout inventory (MBI) em uma amostra de professores de instituições particulares. Psicol Estud 2004 [acesso em 25 jul 2014]; 9(3): 499-55. Disponível em: http://www.scielo.br/scielo.php?pid=S1413$\underline{73722004000300018 \& \text { script=sci_arttext }}$

Carlotto MS, Palazzo LS. Síndrome de burnout e fatores associados: um estudo epidemiológico com professores. Cad Saúde Pública 2006; 22(5): 1017-26.

Carvalho JSFd. "Democratização do ensino" revisitado. Educação e Pesquisa: 2004; 30: 327-34.

Carvalho MMBd. Professor um profissional, sua saúde e a educação em saúde na escola [tese de doutorado]. São Paulo: Faculdade de Saúde Pública da USP; 1995.

Codo W, coordenador. Educação: carinho e trabalho. $3^{\mathrm{a}}$ ed. Petrópolis, RJ: Vozes; 2002.

Diagnóstico e Manejo das Doenças Relacionadas com o Trabalho: Manual de Procedimentos para os Serviços de Saúde Ministério da Saúde - OPS. Anexo: Lista de doenças relacionadas com o trabalho do Ministério da Saúde [acesso em 25 jul 2014]. Disponível em: http://www.segtreinne.com.br/manuais/lista_doencas_relacionadas_trabalho.pdf

Garcia LP, Benevides-Pereira AMT. Investigando o burnout em professores universitários. Inter Ação Psy 2003; 1(1): 76-89.

Gasparini SM, Barreto SM, Assunção AA. Prevalência de transtornos mentais 
comuns em professores da rede municipal de Belo Horizonte, Minas Gerais, Brasil. Cad Saúde Pública 2006; 22(12); 2679-91.

Gil-Monte PR, Carretero N, Roldán MD, Núñez-Román EM. Prevalencia del síndrome de quemarse por el trabajo (burnout) en monitores de taller para personas con discapacidad. Revista de Psicología del Trabajo y de las Organizaciones: 2005 [acesso em 25 jul 2014]; 21; 107-23. Disponível em:

http://www.redalyc.org/articulo.oa?id=231317039007

Gil-Monte PR. Evaluación psicométrica del síndrome de quermarse por el trabajo (burnout): el cuestionário "CESQT". In: Garrido J. Maldito trabajo!. Barcelona: Granica; 2008. p. 269-91.

Gil-Monte PR, Carlotto MS, Câmara SG. Validação da versão brasileira do "Cuestionario para la evaluación del síndrome de quemarse por el trabajo" em professores. Rev Saúde Pública 2010 fev [acesso em 25 jul 14]; 44 (1): 140-7. Disponível em URL: http://www.scielo.br/scielo.php?pid=S0034$\underline{89102010000100015 \& \text { script }=\text { sci_arttext\#back }}$

Hall E, Hall C, Abaci R. The effects of human relations training on reported teacher stress, pupil control ideology and locus of control. Br J Educ Psychol 1997; 67 (Pt 4): 483-96.

Luk AL, Chan BP, Cheong SW, Ko SK. An exploration of the burnout situation on teachers in two schools in Macau. Soc Indic Res. 2010; 95 (3): 489-502.

Maslach C, Jackson SE. The measurement of experienced burnout. J Occup Behav 1981; 2:99-113.

Maslach C, Schaufeli WB, Leiter MP. Job burnout. Annual Review of Psychology 2001; 52: 397-422.

Maslach C, Jackson SE, Leiter MP, Schwab RL. Maslach burnout inventory Manual and non-reproducible instrument and scoring guides. 3. ed. Mind Garden, Inc., www.mindgarden.com Copyright (C) 1986, 2010.

Mendes R, Dias EC. Da medicina do trabalho à saúde do trabalhador. Rev. Saúde Pública [serial on the Internet]. 1991 Oct [acesso em 22 jul 14]; 25(5): 341-349. Disponível em: http://www.scielo.br/scielo.php?script=sci_arttext\&pid=S003489101991000500003\&lng=en. $\quad$ http://dx.doi.org/10.1590/S0034$\underline{89101991000500003}$

Moreno-Jimenez B, Garrosa-Hernandez E, Gálvez M, González JL, BenevidesPereira AMT. A avaliação do burnout em professores. Comparação de instrumentos: CBP-R e MBI-ED. Psicol estud. 2002; 7 (1): 11-9.

Pereira MA. Violência nas escolas: visão de professores do ensino fundamental 
sobre esta questão [dissertação de mestrado]. Ribeirão Preto: Escola de Enfermagem de Ribeirão Preto - USP; 2003.

Perrenoud P. Construir as competências desde a escola. Porto Alegre: Artmed; 1999.

Santos AA, Nascimento Sobrinho CL. Revisão Sistemática da prevalência da síndrome de burnout em professores do ensino fundamental e médio. Rev. Baiana Saúde Pública 2011; 35 (2): 299-319.

Schaufeli WB, Leiter MP, Maslach C. Burnout: 35 years of research and practice. Career Development International. 2009 [acesso em 25 jul 14]; 14(2-3): 204-20. Disponível em: www.emeraldinsight.com/1362-0436.htm

Souza NA, Leite MP. Condições de trabalho e suas repercussões na saúde dos professores da educação básica no Brasil. Educ Soc 2011 out-dez [acesso em 25 jul 2014]; 32 (117); 1105-21. Disponível em: http://www.scielo.br/scielo.php?script=sci_arttext\&pid=S0101$\underline{73302011000400012 \& \text { lang }=\mathrm{pt}}$

Trindade LdL, Lautert L. Síndrome de Burnout entre os trabalhadores da Estratégia de Saúde da Família. Rev. esc. enferm. USP [serial on the Internet]. 2010 June [acesso em 25 jul 2014]; 44( 2 ): 274-279. Disponível em: http://www.scielo.br/scielo.php?script=sci_arttext\&pid=S0080-

62342010000200005\&lng=en. $\quad$ http://dx.doi.org/10.1590/S0080$\underline{62342010000200005}$

Zhong J, You J, Gan Y, Zhang Y, Lu C, Wang H. Job stress, burnout, depression symptoms, and physical health among chinese university teachers. Psychol Rep 2009; 105 (3 Pt2): 1248-54. 


\section{Anexo 1}

\section{TERMO DE CONSENTIMENTO LIVRE E ESCLARECIDO}

Você está sendo convidado (a) como voluntário (a) a participar da pesquisa: Investigação de esgotamento físico e emocional (burnout) entre professores usuários do Hospital do Servidor Público Municipal (HSPM).

O motivo que nos leva a estudar o esgotamento físico e emocional (burnout) é que este é um dos principais problemas que acometem profissionais da área de serviços (como professores, profissionais de saúde, entre outros) e pode afetar a saúde e o bem-estar dessa população.

O objetivo desse projeto é avaliar se existe burnout entre professores da rede pública municipal de São Paulo usuários do HSPM e identificar como se relaciona às condições de saúde e trabalho nessa população.

O procedimento de coleta dados será a aplicação de questionários e entrevistas que envolvem questões referentes às condições de trabalho e saúde. A coleta será feita na ocasião de seu atendimento psicológico e ocorrerá no início do tratamento. A probabilidade de riscos nesse procedimento é mínima, e não acarretará prejuízo ou desconfortos a você. $\mathrm{O}$ esclarecimento de aspectos relativos à sua saúde é uma possibilidade de benefício.

Você será esclarecido (a) sobre a pesquisa em qualquer aspecto que desejar. Você é livre para recusar-se a participar, retirar seu consentimento ou interromper a participação a qualquer momento. A sua participação é voluntária e a recusa em participar não irá acarretar qualquer penalidade, perda de benefícios ou prejuízo ao seu tratamento.

O pesquisador irá tratar a sua identidade com padrões profissionais de sigilo. Os 
resultados da pesquisa serão transmitidos para você e permanecerão confidenciais. Seu nome ou o material que indique a sua participação não será liberado sem a sua permissão. Você não será identificado (a) em nenhuma publicação que possa resultar deste estudo. Uma cópia deste consentimento informado será arquivada no Departamento de Epidemiologia da Faculdade de Saúde Pública da Universidade de São Paulo e outra será fornecida a você.

A participação no estudo não acarretará custos para você e não será disponível nenhuma compensação financeira adicional.

$\mathrm{Eu}$, fui informada (o) dos objetivos da pesquisa acima de maneira clara e detalhada e esclareci minhas dúvidas. Sei que em qualquer momento poderei solicitar novas informações e motivar minha decisão se assim o desejar. A professora orientadora Prof ${ }^{a}$. Dr ${ }^{a}$. $M^{a}$. Regina A. Cardoso certificou-me de que todos os dados desta pesquisa serão confidenciais.

Também sei que caso existam gastos adicionais, estes serão absorvidos pelo orçamento da pesquisa. Em caso de dúvidas poderei chamar a pesquisadora Elaine Cristina Simões ou a professora orientadora Prof ${ }^{a}$. Dr ${ }^{a}$. M ${ }^{a}$. Regina A. Cardoso no telefone (11) 981-543-155 ou o Comitê de Ética em Pesquisa da Faculdade de Saúde Pública da Universidade de São Paulo, sito à Av. Dr. Arnaldo, 715, Cerqueira César - São Paulo, SP ou ainda o Comitê de Ética em Pesquisa do Hospital do Servidor Público Municipal através do telefone (11) 3397-8069.

Declaro que concordo em participar desse estudo. Recebi uma cópia deste termo de consentimento livre e esclarecido e me foi dada a oportunidade de ler e esclarecer as minhas dúvidas.

Nome Assinatura do Participante Data

Nome Assinatura do Pesquisador Data




\section{Anexo 2}

\section{Cuestionário para la Evaluación del Síndrome de Quemarse por el Trabajo.}

Iniciais do nome:

$$
0
$$

Nunca
1

Raramente: algumas vezes por ano data:

$$
2
$$

As vezes: algumas vezes por mês 3

Frequentemente: algumas vezes por semana

1. O meu trabalho representa para mim um desafio estimulante.

2. Não gosto de atender alguns alunos.

3. Acho que muitos alunos são insuportáveis.

4. Preocupa-me a forma como tratei algumas pessoas no trabalho.

5. Vejo o meu trabalho como uma fonte de realização pessoal.

6. Acho que os familiares dos alunos são uns chatos.

7. Penso que trato com indiferença alguns alunos.

8. Penso que estou saturado(a) pelo meu trabalho.

9. Sinto-me culpado(a) por alguma das minhas atitudes no trabalho.

10. Penso que o meu trabalho me dá coisas positivas.

11. Gosto de ser irônico(a) com alguns alunos.

12. Sinto-me pressionado(a) pelo trabalho.

13. Tenho remorsos por alguns dos meus comportamentos no trabalho.

14. Rotulo ou classifico os alunos segundo o seu comportamento.

15. O meu trabalho me é gratificante.

16. Penso que deveria pedir desculpas a alguém pelo meu comportamento no trabalho.

17. Sinto-me cansado(a) fisicamente no trabalho.

18. Sinto-me desgastado(a) emocionalmente.

19. Sinto-me encantado(a) pelo meu trabalho.

20. Sinto-me mal por algumas coisas que disse no trabalho.
4

Muito frequentemente: todos os dias

Rev Saúde Pública 2010;44(1):140-7 Anexo. "Cuestionario para la Evaluación del Síndrome de Quemarse por el Trabajo". 


\section{Anexo 3}

\section{Roteiro de Entrevista}

Iniciais:

Data:

1. Qual o motivo que o leva a procurar atendimento psicológico?

2. Avalia que a procura pela psicoterapia está relacionada ao seu trabalho?

3. Sente-se bem no trabalho?

4. A atividade docente tem correspondido ao que você esperava dela?

5. Houve suspensão nas atividades escolares (greve, paralisação) nos últimos doze meses? Por que razão?

6. Como avalia seu relacionamento com os alunos?

7. Como avalia seu relacionamento com os pais?

8. Como avalia seu relacionamento com os colegas?

9. Como avalia seu relacionamento com a direção/coordenação?

10. Como avalia as condições de segurança na escola?

11. Como avalia as condições de segurança nas áreas próximas à escola?

12. Pensa em se aposentar?

13. Como imagina seu futuro após a aposentadoria? 


\section{Anexo 4}

\section{Aspectos sócio-demográficos e ocupacionais - Professores Municipais}

1. Iniciais do nome:

Registro Funcional:

2. Sexo:

Data de nascimento:

3. Local de residência:

Bairro:

Região:

CEP:

4. Local de trabalho:

Bairro:

Região:

CEP:

5. Escolaridade:

(fundamental) (médio) (superior em

.) (pós-graduação em

6. Estado civil:

7. Quantos filhos você tem ou cuida:

8. Quantas pessoas moram na residência:

9. Você é o (a) chefe da família? (Sim) (Não)

10. Além de você, há outras rendas na residência? (Sim) (Não)

11. Existem outras rendas na residência? (Pais) (Irmãos) (Cônjuge) (Filhos) (Outros)

12. Qual a renda aproximada da família?

13. O que costuma fazer em seu tempo livre, ou como laser?

Aspectos Ocupacionais:

1. Desde quando você é professor (a)? mês: ano:

2. Desde quando você é docente na rede pública municipal? mês: ano:

3. Atualmente, você assume quantos cargos de professor? (Um) (Dois) (Três)

4. Jornada: (JB-20h) (JBD-30h) (JEIF-40h)

5. Que nível você atende: (educação infantil) (fundamental I) (fundamental II) ( ensino médio)

6. Você está: (Ativa) (Readaptado) (Licença___)

7. Se você está readaptado, há quanto tempo?

8. Você trabalha como professor na rede estadual? (Sim) (Não)

9. Quantas horas por semana você trabalha como professor estadual?

10. Você trabalha como professor em escola particular? (Sim) (Não) 
11. Quantas horas por semana você trabalha como professor em escola particular?

12. Além de professor (a), trabalha em outra função? (Sim) (Não)

13. Que função?

14. Quantas horas por semana você trabalha em outra função?

15. No total você trabalha quantas horas por semana?

\section{Aspectos Motivacionais:}

1. Sente-se realizado como professor? (Sim) (Não) (Não sabe dizer)

2. Gostaria de trabalhar em outra ocupação? (Sim) (Não)

3. Qual seria essa ocupação?

4. Por que se interessa por essa outra ocupação?

Ambiente físico da escola e das salas de aula:

1. A iluminação das salas de aula é em sua maior parte aceitável? (Sim) (Não)

2. A limpeza das salas de aula é em sua maior parte aceitável? (Sim) (Não)

3. O nível de poeira das salas de aula é em sua maior parte aceitável? (Sim) (Não)

4. Os recursos materiais disponíveis para o trabalho são adequados? (Sim) (Não)

5. Há falta de recursos materiais necessários para o trabalho? (Sim) (Não)

6. Quais recursos materiais seriam necessários?

7. A acústica das salas de aula é em sua maior parte aceitável? (Sim) (Não)

8. O nível de ruído na sala de aula o incomoda? (Sim) (Não) (Às vezes)

9. O nível de ruído na escola o incomoda? (Sim) (Não) (Às vezes)

10. Existe local para descanso na escola? (Sim) (Não)

11. Existe comunidade muito carente ou favela próxima à escola? (Sim) (Não)

12. Observa algum problema na escola que o incomoda ou que necessitaria ser sanado? (Sim) (Não)

13. Qual é esse problema?

14. Por que esse problema o incomoda?

Contato com os alunos, pais e colegas:

1. Quantos alunos atende diariamente?

2. O contato com os alunos o incomoda? (Sim) (Não) (Às vezes) 
3. Por quê?

4. Considera que há elevado número de alunos por classe? (Sim) (Não)

5. Observa mau comportamento dos alunos? (Sim) (Não)

6. Com que frequência? (Diariamente) (Semanalmente) (Às vezes)

7. Sente necessidade de atualização profissional? (Sim) (Não)

8. Considera estar sobrecarregado de atividades? (Sim) (Não)

9. A necessidade de execução de atividades burocráticas é excessiva? (Sim) (Não)

10. O contato com os pais dos alunos ocorre em horários programados? (Sim) (Não)

11. O contato com os pais dos alunos o incomoda? (Sim) (Não) (Às vezes)

12. Se sim ou às vezes, explique por que.

13. Sente falta de apoio da coordenação da escola? (Sim) (Não) (Às vezes)

14. Sente falta de apoio de seus colegas? (Sim) (Não) (Às vezes)

15. Sente que participa das decisões institucionais? (Sim) (Não) (Às vezes)

Aspectos relacionados à saúde e licenças médicas:

1. Já realizou quantas sessões de psicoterapia? (ainda não iniciou) (de 1 a 8$)$ (+ q 8)

2. Como você descreveria sua saúde? (Ótima) (Boa) (Regular) (Ruim) (Frágil)

3. Você usa algum medicamento regularmente? (Sim) (Não)

4. Qual medicamento?

5. Por qual motivo?

6. Você tem algum tipo de problema de saúde? (Sim) (Não)

7. Que tipo?

8. Há quanto tempo tem este problema?

9. Você já fez algum tratamento de saúde? (Sim) (Não)

10. Que tratamento?

11. Por quanto tempo?

12. Você já se ausentou por licença médica? (Sim) (Não)

13. Se sim, quantas vezes se afastou? (entre 1 e 2) (entre 2 e 4) (entre 5 e 8) (mais que 8 vezes)

14. Quanto tempo durou seu período de licença médica mais longo?

15. Que tipo de problema de saúde ocasionou sua última licença médica? (Problemas Emocionais) (Problemas Gastrointestinais) (Problemas Vocais) (Dor muscular) 
(Outros)

16. Acha que seus problemas de saúde tem relação com seu trabalho? (Sim) (Não) (Não sabe dizer)

17. Se acha que tem relação, explique por que.

Aspectos relacionados à violência, ou agressividade, dentro e fora da escola:

1. Sofreu algum tipo de agressão fora da escola nos últimos doze meses? (Sim) (Não)

2. Se sim, que tipo de agressão ocorreu?

3. Acha que teve algum dano físico ou psicológico devido a esse fato? (Sim) (Não)

4. Se sim, que tipo de dano avalia que ocorreu em você devido a esse fato?

5. Sofreu algum tipo de agressão na escola nos últimos doze meses? (Sim) (Não)

6. Se sim, que tipo de agressão ocorreu?

7. Acha teve algum dano físico ou psicológico devido a esse fato? (Sim) (Não)

8. Se sim, que tipo de dano avalia que ocorreu em você devido a esse fato?

9. Conhece pessoas que sofreram agressão nos últimos doze meses? (Sim) (Não)

10. Se sim, que tipo de agressão ocorreu?

11. Se sim, quem é a pessoa a que se refere? (Parente) (Amigo) (Colega) (Aluno) (Outros)

12. Acha que a pessoa teve algum dano físico ou psicológico devido a esse fato? (Sim) (Não)

13. Se sim, que tipo de dano avalia que ocorreu na pessoa a que se refere, devido a esse fato?

No espaço abaixo você poderá registrar assuntos não abordados aqui ou que você queira comentar. 


\section{Anexo 5}

\section{Relação completa de medicamentos em uso regular}

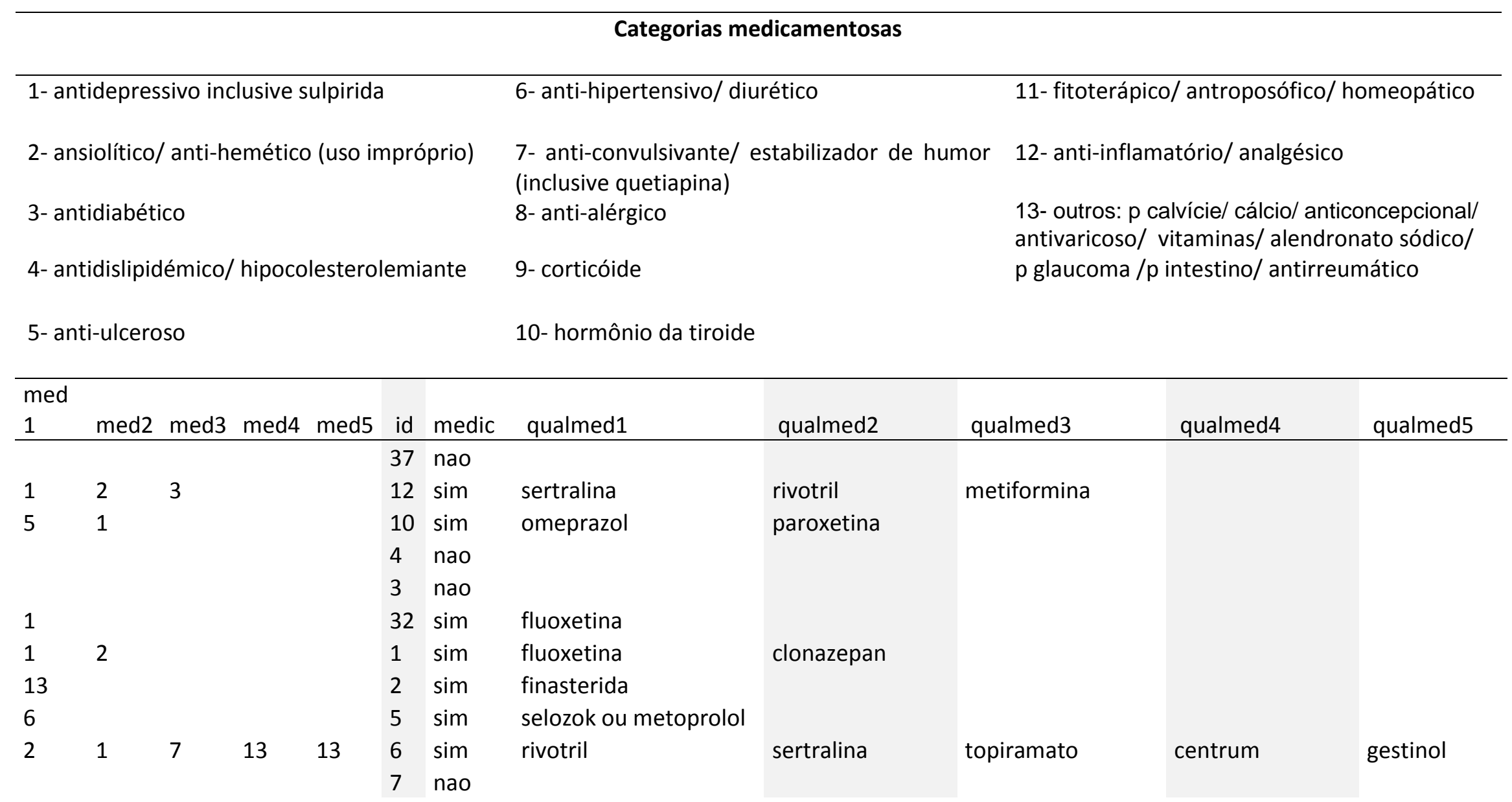




\begin{tabular}{|c|c|c|c|c|c|c|c|c|c|c|c|}
\hline \multirow[t]{3}{*}{3} & \multicolumn{4}{|l|}{1} & 8 & $\operatorname{sim}$ & \multirow[t]{3}{*}{$\begin{array}{l}\text { janumet (sitagliptina e } \\
\text { metformina) }\end{array}$} & \multirow[t]{3}{*}{$\begin{array}{l}\text { escilex } \\
\text { (escitalopram) }\end{array}$} & & & \\
\hline & & & & & 9 & nao & & & & & \\
\hline & & & & & 11 & nao & & & & & \\
\hline 5 & 11 & & & & 13 & $\operatorname{sim}$ & prazol (Lansoprazol) & (homeopático) & & & \\
\hline 6 & & & & & 14 & sim & $\begin{array}{l}\text { lozartana } \\
\text { glifage xr500 }\end{array}$ & & & & \\
\hline 3 & 4 & 13 & 5 & 13 & 15 & $\operatorname{sim}$ & $\begin{array}{l}\text { (metmorfina) } \\
\text { loratadina (anti- }\end{array}$ & $\begin{array}{l}\text { sinvastatina } \\
\text { clenil spray }\end{array}$ & vitamina D e E & pantoprazol & varicoss \\
\hline 8 & 9 & 5 & & & 16 & $\operatorname{sim}$ & alérgico) & (beclometasona) & omeprazol & & \\
\hline 3 & 10 & 6 & 11 & 4 & 17 & $\operatorname{sim}$ & $\begin{array}{l}\text { vildagliptina e } \\
\text { glimepirida }\end{array}$ & $\begin{array}{l}\text { syntroid } \\
\text { (Levotiroxina) } \\
\text { "remédio } p\end{array}$ & losartana & $\begin{array}{l}\text { (valeriana } \\
\text { officinali }\end{array}$ & sinvastatina \\
\hline 10 & 4 & & & & 18 & $\operatorname{sim}$ & puran T4 & colesterol" & & & \\
\hline 1 & & & & & 19 & $\operatorname{sim}$ & equilid (Sulpirida) & & & & \\
\hline 2 & 1 & & & & 20 & $\operatorname{sim}$ & frontal (alprazolam) & sertralina & & & \\
\hline 1 & 2 & 7 & 6 & & 21 & sim & fluoxetina & rivotril & $\begin{array}{l}\text { estabilizador } \\
\text { humor (n s nome) }\end{array}$ & $\begin{array}{l}\text { ara2 (Losartan } \\
\text { Potássico) }\end{array}$ & \\
\hline 3 & 6 & 7 & 1 & 2 & 22 & $\operatorname{sim}$ & $\begin{array}{l}\text { metformina } \\
\text { dorflex }\end{array}$ & enalapril & quetiapina & sertralina & rivotril \\
\hline 12 & & & & & 23 & sim & (dipirona,orfenadrina) & & & & \\
\hline 1 & & & & & 24 & $\operatorname{sim}$ & amitriptilina & & & & \\
\hline 6 & 6 & 1 & & & 25 & $\operatorname{sim}$ & enalapril & $\begin{array}{l}\text { propanolol } \\
\text { medicação }\end{array}$ & nortriptilina & & \\
\hline 10 & 11 & 13 & & & 26 & $\operatorname{sim}$ & puran T4 (Levotiroxina) & antroposófica & vitamina pré natal & & \\
\hline & & & & & 27 & nao & & & & & \\
\hline$x 6$ & 4 & 4 & 1 & & 28 & sim & 3 antihipertensivos & acido & "1 p colesterol" & fluoxetina & \\
\hline
\end{tabular}




\begin{tabular}{|c|c|c|c|c|c|c|c|c|c|c|c|}
\hline & & & & & & & & & & & \\
\hline 10 & 4 & 12 & & & 29 & $\operatorname{sim}$ & puran t4 (levotiroxina) & $\begin{array}{l}\text { acetilsalicílico } \\
\text { sinvastatina }\end{array}$ & $\begin{array}{l}\text { "fórmula p inflamç } \\
\text { do joelho" }\end{array}$ & & \\
\hline 6 & 5 & 4 & & & 30 & $\operatorname{sim}$ & atenolol & ranitidina & (Ciprofibrato) & & \\
\hline & & & & & 31 & nao & & & & & \\
\hline & & & & & 33 & nao & & & & & \\
\hline 12 & 5 & 13 & & & 34 & $\operatorname{sim}$ & naratriptana & omeprazol & $\begin{array}{l}\text { glaucotrat } \\
\text { (timolol) }\end{array}$ & & \\
\hline 5 & & & & & 35 & $\operatorname{sim}$ & omeprazol & & & & \\
\hline 5 & 10 & 1 & & & 36 & $\operatorname{sim}$ & omeprazol & $\begin{array}{l}\text { tapazol } \\
\text { (tiamazol) }\end{array}$ & sertralina & & \\
\hline & & & & & 38 & nao & & & & & \\
\hline 10 & 6 & 6 & 4 & 3 & 39 & sim & puran t4 (levotiroxina) & $\begin{array}{l}\text { higroton } \\
\text { clenil }\end{array}$ & enalapril & $\begin{array}{l}\text { atorvastatina } \\
\text { tylex (codeína e }\end{array}$ & metformina \\
\hline 6 & 9 & 8 & 12 & & 40 & $\operatorname{sim}$ & losartan & (beclometasona) & loratadina & paracetamol) & \\
\hline 6 & 3 & 4 & & & 41 & $\operatorname{sim}$ & losartana & metformina & sinvastatina & & \\
\hline 2 & & & & & 42 & $\operatorname{sim}$ & clopan (clonazepam) & & & & \\
\hline 4 & 10 & 8 & 9 & 1 & 43 & sim & sinvastatina & levotiroxina & "p rinite alérgica" & budesonida & fluoxetina \\
\hline & & & & & 44 & nao & & & & & \\
\hline & & & & & 45 & nao & & & & & \\
\hline 6 & 6 & 12 & & & 46 & sim & captopril (Capoten) & hidroclorotiazida & remédio p coluna & & \\
\hline & & & & & 47 & nao & & & & & \\
\hline 6 & 6 & 11 & & & 48 & sim & losartana & atenolol & pasalix (Passiflora) & & \\
\hline 4 & 1 & & & & 49 & $\operatorname{sim}$ & "p colesterol" & fluoxetina & & & \\
\hline 3 & 6 & 13 & 13 & & 50 & $\operatorname{sim}$ & metformina & losartan & glicamida & cálcio & \\
\hline & & & & & 51 & nao & & & & & \\
\hline 10 & 3 & 6 & 12 & 5 & 52 & sim & puran (levotiroxina) & metformina & losartana & ibuprofeno & omeprazol \\
\hline 6 & & & & & 53 & $\operatorname{sim}$ & captopril (capoten) & & & & \\
\hline
\end{tabular}




\begin{tabular}{|c|c|c|c|c|c|c|c|c|c|c|c|}
\hline & & & & & 54 & nao & & & & & \\
\hline & & & & & 55 & nao & & & & & \\
\hline 11 & 4 & 13 & 13 & 13 & 56 & $\operatorname{sim}$ & iperisan (Hypericum) & $\begin{array}{l}\text { lipless } \\
\text { (ciprofibrato) }\end{array}$ & $\begin{array}{l}\text { oscal D (cálcio e vit } \\
\text { D) }\end{array}$ & $\begin{array}{l}\text { alendronato } \\
\text { sódico }\end{array}$ & óleo mineral \\
\hline 3 & 2 & 1 & & & 57 & $\operatorname{sim}$ & metformina & rivotril & sertralina & & \\
\hline 6 & & & & & 58 & $\operatorname{sim}$ & losartana & & & & \\
\hline & & & & & 59 & nao & & & & & \\
\hline 1 & 1 & 5 & 13 & 4 & 60 & $\operatorname{sim}$ & $\begin{array}{l}\text { amitriptilina } \\
\text { depakote (divalproato }\end{array}$ & sertralina & omeprazol & $\begin{array}{l}\text { reuquinol (hidro } \\
\text {-xicloroquina }\end{array}$ & sinvastatina \\
\hline 7 & & & & & 61 & $\operatorname{sim}$ & d sódio) & & & & \\
\hline 1 & 1 & 6 & & & 62 & $\operatorname{sim}$ & razapina (mirtazapina) & venlafaxina & losartana & & \\
\hline 6 & 6 & 4 & 1 & 2 & 63 & $\operatorname{sim}$ & captopril & hidroclorotiazida & sinvastatina & sertralina & clonazepam \\
\hline 1 & & & & & 64 & $\operatorname{sim}$ & $\begin{array}{l}\text { fluoxetina } \\
\text { trileptal }\end{array}$ & & & & \\
\hline 7 & 1 & 13 & 6 & & 65 & $\operatorname{sim}$ & $\begin{array}{l}\text { (oxcarbazepina ) } \\
\text { dramin }\end{array}$ & citalopram & (noretisterona) & losartana & \\
\hline 2 & & & & & 66 & $\operatorname{sim}$ & (dimenidrinato) & & & & \\
\hline & & & & & 67 & nao & & & & & \\
\hline 1 & 4 & & & & 68 & $\operatorname{sim}$ & sertralina & $\begin{array}{l}\text { sinvastatina } \\
\text { puran } 88\end{array}$ & & & \\
\hline 1 & 10 & & & & 69 & $\operatorname{sim}$ & citalopran & $\begin{array}{l}\text { (Levotiroxina) } \\
\text { venalot(cumarina }\end{array}$ & & & \\
\hline 6 & 6 & 13 & 1 & 6 & 70 & $\operatorname{sim}$ & $\begin{array}{l}\text { hidrocloritiazida } \\
\text { alenia -formoterol }\end{array}$ & $\begin{array}{l}\text { e troxerruti } \\
\text { "vacina para }\end{array}$ & atenolol & sertralina & losartana \\
\hline 9 & 8 & & & & 71 & $\operatorname{sim}$ & budesonida & rinite" & & & \\
\hline 10 & 7 & & & & 72 & $\operatorname{sim}$ & puran (levotiroxina) & topiramato & & & \\
\hline 4 & 5 & 1 & 13 & & 73 & $\operatorname{sim}$ & ezetimiba sinvastati & lansoprazol & fluoxetina & vitaminas & \\
\hline 1 & & & & & 74 & $\operatorname{sim}$ & sertralina & & & & \\
\hline
\end{tabular}


12

$7 \quad 1$
75 sim

$76 \mathrm{sim}$ fluoxetina

quetiapina bromazepan

desvenlafaxina 


\section{Anexo 6}

Apuração de resultados individuais no MBI

\begin{tabular}{|c|c|c|c|c|c|c|c|c|c|c|c|c|c|}
\hline & Ind1 & Ind2 & Ind3 & Ind4 & Ind5 & Ind6 & Ind7 & Ind8 & Ins9 & Ind10 & Ind11 & Ind12 & Ind13 \\
\hline EE & 16 & 25 & 34 & 31 & 19 & 40 & 53 & 53 & 49 & 33 & 31 & 53 & 11 \\
\hline De & 0 & 17 & 12 & 0 & 1 & 3 & 11 & 1 & 15 & 5 & 10 & 14 & 0 \\
\hline E P & 38 & 37 & 29 & 29 & 21 & 23 & 12 & 16 & 19 & 31 & 36 & 19 & 43 \\
\hline
\end{tabular}

\begin{tabular}{|c|c|c|c|c|c|c|c|c|c|c|c|c|c|}
\hline & Ind14 & Ind15 & Ind16 & Ind17 & Ind18 & Ind19 & Ind20 & Ind21 & Ind22 & Ind23 & Ind24 & Ind25 & Ind26 \\
\hline EE & 8 & 20 & 25 & 38 & 28 & 44 & 48 & 48 & 48 & 37 & 14 & 36 & 47 \\
\hline De & 2 & 0 & 2 & 8 & 4 & 6 & 17 & 12 & 16 & 11 & 4 & 10 & 5 \\
\hline EP & 17 & 37 & 33 & 26 & 41 & 24 & 15 & 22 & 18 & 31 & 32 & 39 & 44 \\
\hline
\end{tabular}

\begin{tabular}{|c|c|c|c|c|c|c|c|c|c|c|c|c|c|}
\hline & Ind27 & Ind28 & Ind29 & Ind30 & Ind31 & Ind32 & Ind33 & Ind34 & Ind35 & Ind36 & Ind37 & Ind38 & Ind39 \\
\hline EE & 40 & 42 & 37 & 42 & 11 & 39 & 5 & 31 & 22 & 54 & 38 & 31 & 28 \\
\hline De & 22 & 15 & 2 & 13 & 3 & 8 & 1 & 9 & 5 & 23 & 0 & 2 & 0 \\
\hline EP & 22 & 18 & 25 & 26 & 37 & 37 & 44 & 28 & 39 & 16 & 37 & 33 & 33 \\
\hline
\end{tabular}




\begin{tabular}{|c|c|c|c|c|c|c|c|c|c|c|c|c|c|}
\hline & Ind40 & Ind41 & Ind42 & Ind43 & Ind44 & Ind45 & Ind46 & Ind47 & Ind48 & Ind49 & Ind50 & Ind51 & Ind52 \\
\hline $\mathrm{EE}$ & 48 & 15 & 11 & 14 & 47 & 51 & 16 & 30 & 32 & 44 & 37 & 13 & 21 \\
\hline De & 6 & 2 & 5 & 1 & 6 & 5 & 2 & 4 & 1 & 13 & 9 & 1 & 1 \\
\hline EP & 39 & 38 & 34 & 30 & 36 & 26 & 40 & 32 & 29 & 11 & 30 & 8 & 44 \\
\hline
\end{tabular}

\begin{tabular}{|c|c|c|c|c|c|c|c|c|c|c|c|c|c|}
\hline & Ind53 & Ind54 & Ind55 & Ind56 & Ind57 & Ind58 & Ind59 & Ind60 & Ind61 & Ind62 & Ind63 & Ind64 & Ind65 \\
\hline$\overline{E E}$ & 11 & 30 & 33 & 39 & 47 & 18 & 25 & 49 & 35 & 18 & 32 & 21 & 47 \\
\hline De & 1 & 13 & 6 & 0 & 8 & 0 & 4 & 0 & 16 & 12 & 6 & 0 & 5 \\
\hline EP & 39 & 32 & 38 & 30 & 8 & 40 & 27 & 12 & 34 & 10 & 45 & 39 & 41 \\
\hline
\end{tabular}

\begin{tabular}{llllllllllll}
\hline & Ind66 & Ind67 & Ind68 & Ind69 & Ind70 & Ind71 & Ind72 & Ind73 & Ind74 & Ind75 & Ind76 \\
\hline EE & 34 & 9 & 37 & 39 & 18 & 35 & 42 & 22 & 38 & 41 & 34 \\
De & 3 & 0 & 9 & 8 & 3 & 6 & 7 & 2 & 12 & 12 & 2 \\
EE & 22 & 46 & 42 & 36 & 38 & 29 & 28 & 32 & 33 & 16 & 39 \\
\hline
\end{tabular}




\section{Anexo 7}

\section{Apuração de resultados individuais no CESQT}

\begin{tabular}{|c|c|c|c|c|c|c|c|c|c|c|c|c|c|}
\hline & Ind1 & Ind2 & Ind3 & Ind4 & Ind5 & Ind6 & Ind7 & Ind8 & Ins9 & Ind10 & Ind11 & Ind12 & Ind13 \\
\hline IT & 3,6 & 2,8 & 0,8 & 3 & 2,2 & 2,6 & 0,6 & 2 & 2,4 & 2,2 & 3 & 0,4 & 3,6 \\
\hline DP & 2,25 & 2,25 & 2,5 & 3,5 & 1,5 & 3 & 4 & 4 & 3,25 & 2,5 & 3 & 2,75 & 1 \\
\hline Ind & 0,166667 & 0,166667 & 2,5 & 0,666667 & 0,333333 & 1,5 & 2 & 1,5 & 2,333333 & 0,666667 & 0,833333 & 2 & 0,5 \\
\hline Cul & 1 & 3,8 & 1,8 & 1,6 & 1,8 & 2 & 3,6 & 2 & 2,4 & 0,4 & 2,8 & 1,6 & 0,8 \\
\hline
\end{tabular}

\begin{tabular}{|c|c|c|c|c|c|c|c|c|c|c|c|c|c|}
\hline & Ind14 & Ind15 & Ind16 & Ind17 & Ind18 & Ind19 & Ind20 & Ind21 & Ind22 & Ind23 & Ind24 & Ind25 & Ind26 \\
\hline IT & 1,4 & 3,2 & 3,8 & 3,6 & 3,2 & 2,8 & 1 & 1,6 & 1 & 2 & 4 & 2,6 & 4 \\
\hline DP & 0 & 2,25 & 3 & 3,25 & 2,5 & 3 & 4 & 3,75 & 3,5 & 2,75 & 0,75 & 2,25 & 2,75 \\
\hline Ind & 0,833333 & 1,333333 & 0,666667 & 0,666667 & 0,5 & 0,833333 & 2,5 & 1,333333 & 3,666667 & 0,666667 & 0,166667 & 1,5 & 0,666667 \\
\hline Cul & 0,4 & 1 & 1,8 & 2,8 & 3,6 & 1 & 3,2 & 2,4 & 2,8 & 0,2 & 1 & 0,6 & 1,4 \\
\hline
\end{tabular}

\begin{tabular}{|c|c|c|c|c|c|c|c|c|c|c|c|c|c|}
\hline & Ind27 & Ind28 & Ind29 & Ind30 & Ind31 & Ind32 & Ind33 & Ind34 & Ind35 & Ind36 & Ind37 & Ind38 & Ins39 \\
\hline IT & 2,4 & 1,8 & 2,8 & 1,2 & 3,6 & 3 & 3,8 & 3,8 & 3 & 0 & 3 & 2,4 & 1,6 \\
\hline DP & 3 & 3,5 & 3 & 1 & 1,25 & 3,25 & 0,5 & 2,25 & 1,5 & 4 & 2,75 & 2,75 & 2 \\
\hline Ind & 2,5 & 1,5 & 0,833333 & 1,5 & 0,666667 & 1,833333 & 1,666667 & 2,833333 & 0,833333 & 3,166667 & 0,5 & 1,833333 & 0,666667 \\
\hline Cul & 4 & 1 & 0,2 & 1 & 2,2 & 2 & 2,2 & 3,4 & 0,2 & 2,4 & 2 & 0,4 & 1 \\
\hline
\end{tabular}




\begin{tabular}{|c|c|c|c|c|c|c|c|c|c|c|c|c|c|}
\hline & Ind140 & Ind41 & Ind142 & Ind43 & Ind144 & Ind45 & Ind46 & Ind47 & Ind48 & Ind49 & Ind50 & Ind51 & Ind52 \\
\hline IT & 2 & 3,4 & 3 & 2,4 & 2,2 & 1,4 & 4 & 2,6 & 3,2 & 0,8 & 2,6 & 1,8 & 3,4 \\
\hline DP & 3,5 & 2 & 0,75 & 1,75 & 2,75 & 3,75 & 1,75 & 2,5 & 2,25 & 3,75 & 2,5 & 2 & 3 \\
\hline Ind & 2 & 1,166667 & 1 & 0,166667 & 1,5 & 1,833333 & 1 & 1,166667 & 0,5 & 2,5 & 1,166667 & 1,166667 & 0,666667 \\
\hline Cul & 1,4 & 1,6 & 1,6 & 0 & 0,8 & 1,6 & 2,6 & 0,4 & 1,6 & 3 & 2,4 & 1,2 & 1,2 \\
\hline
\end{tabular}

\begin{tabular}{|c|c|c|c|c|c|c|c|c|c|c|c|c|c|}
\hline & Ind53 & Ind54 & Ind55 & Ind56 & Ind57 & Ind58 & Ind59 & Ind60 & Ind 61 & Ind62 & Ind63 & Ind64 & Ind65 \\
\hline IT & 3 & 2,4 & 3,8 & 2,2 & 0,6 & 3,4 & 2 & 1,4 & 1,4 & 1,6 & 3,6 & 2 & 3,8 \\
\hline DP & 1,5 & 2 & 2,75 & 3,75 & 3,5 & 3 & 2,5 & 3,75 & 2 & 1 & 2,5 & 2 & 2,75 \\
\hline Ind & 0,5 & 1,666667 & 1,333333 & 1,166667 & 2,833333 & 0,833333 & 1 & 2,166667 & 1 & 2,833333 & 0,833333 & 0,166667 & 1,833333 \\
\hline Cul & 1,6 & 2,8 & 0,6 & 3,4 & 2,2 & 2,2 & 1 & 1 & 1,4 & 1 & 1 & 0,8 & 3 \\
\hline
\end{tabular}

\begin{tabular}{llllllllllll}
\hline & Ind66 & Ind67 & Ind68 & Ind69 & Ind70 & Ind71 & Ind72 & Ind73 & Ind74 & Ind75 & Ind76 \\
\hline IT & 2,6 & 4 & 2,8 & 2,8 & 4 & 2,4 & 2 & 3 & 3,2 & 1,2 & 3,2 \\
DP & 2,5 & 1 & 2,5 & 2,5 & 2,5 & 2,5 & 3,25 & 2 & 3,5 & 3,75 & 2,25 \\
Ind & 0,833333 & 0 & 1,5 & 0,333333 & 1 & 1,5 & 1,166667 & 1 & 0 & 1,5 & 0,5 \\
Cul & 1 & 1,6 & 3 & 0 & 2 & 1,2 & 1 & 0,8 & 1,6 & 1,2 & 1,2 \\
\hline
\end{tabular}

